The Life of The Bee Maurice Maeterlinck s 


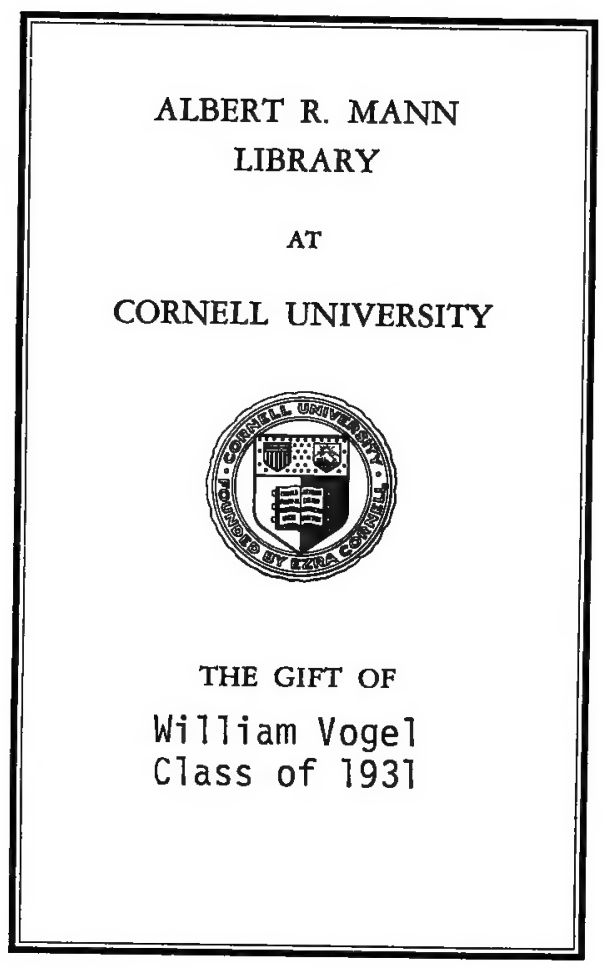


31924089524106

Lawas on. Proure Geumer cala. 


\section{Cornell University Library}

The original of this book is in the Cornell University Library.

There are no known copyright restrictions in the United States on the use of the text.

http://www.archive.org/details/cu31924089524106 
. 


\section{THE LIFE OF THE BEE}




\section{By the Same Author:}

THE TREASURE OF THE HUMBLE. Translated by Alfred Sutro. I 2 mo. \$1.75.

WISDOM AND DESTINY. Translated by Alfred Sutro. $12 \mathrm{mo} . \$ 1.75$.

THE LIFE OF THE BEE. Translated by Alfred Sutro. $12 \mathrm{mo}$. \$1.40 net.

SISTER BEATRICE AND ARDIANE AND BARBE BLEUE. Translated by BERNARD MIALL. $12 \mathrm{mo}$. \$1.20 net.

THE BURIED TEMPLE. Translated by ALFred Sutro. $12 \mathrm{mo}$. \$1.40 net.

THOUGHTS FROM MAETERLINCK. Arranged by E. S. S. $12 \mathrm{mo}$. $\$ 1.20$ net.

THE DOUBLE GARDEN. Translated by alexander Teixeira de Mattos. $12 \mathrm{mo}$. $\$ \mathrm{I} .40$ net. 


\section{The Life of the Bee}

BY

MAURICE MAETERLINCK

Translated by

ALFRED SUTRO

es

NEW YORK

DODD, MEAD AND COMPANY

1910 
MANN

SPEC. COLL.

PHILLIPS

QL

568

AG

$M 18$

1901

Copyright, rooT

By Dodo, Mead and Company

All rights reserved

Published May, Igor

UNIVERSITY PRESS - JOHN WILSON

AND SON - CAMBRIDGE, U.S.A. 


\section{Contents}

Pagr

I. On the Threshold of the Hive 3

II. The Swarm • • • • • • • 37

III. The Foundation of the City . I3I

IV. The Life of the Bee • • • . 159

V. The Young Queens • • . 233

VI. The Nuptial Flight • • • 295

VII. The Massacre of the Males - 347

VIII. The Progress of the Race. · · 363

ApPEndIX . . . . . . . . $\cdot 423$ 

I

ON THE THRESHOLD OF THE HIVE 



\title{
The Life of the Bee
}

\author{
I \\ ON THE THRESHOLD OF \\ THE HIVE \\ [ I ]
}

T $T$ is not my intention to write a trea1 tise on apiculture, or on practical bee-keeping. Excellent works of the kind abound in all civilised countries, and it were useless to attempt another. France has those of Dadant, Georges de Layens and Bonnier, Bertrand, Hamet, Weber, Clement, the Abbé Collin, etc. English-speaking countries have Langstroth, Bevan, Cook, Cheshire, Cowan, Root, etc. Germany has Dzierzon, Van Berlespoch, Pollmann, Vogel, and many others. 


\section{The Life of the Bee}

Nor is this book to be a scientific monograph on Apis Mellifica, Ligustica, Fasciata, Dorsata, etc., or a collection of new observations and studies. I shall say scarcely anything that those will not know who are somewhat familiar with bees. The notes and experiments $I$ have made during my twenty years of beekeeping I shall reserve for a more technical work; for their interest is necessarily of a special and limited nature, and I am anxious not to over-burden this essay. I wish to speak of the bees very simply, as one speaks of a subject one knows and loves to those who know it not. I do not intend to adorn the truth, or merit the just reproach Réaumur addressed to his predecessors in the study of our honey-flies, whom he accused of substituting for the marvellous reality marvels that were imaginary and merely plausible. The fact that the hive con- 


\section{On the Threshold of the Hive}

tains so much that is wonderful does not warrant our seeking to add to its wonders. Besides, I myself have now for a long time ceased to look for anything more beautiful in this world, or more interesting, than the truth; or at least than the effort one is able to make towards the truth. I shall state nothing, therefore, that I have not verified myself, or that is not so fully accepted in the text-books as to render further verification superfluous. My facts shall be as accurate as though they appeared in a practical manual or scientific monograph, but I shall relate them in a somewhat livelier fashion than such works would allow, shall group them more harmoniously together, and blend them with freer and more mature reflections. The reader of this book will not learn therefrom how to manage a hive; but he will know more or less all that can with any 


\section{The Life of the Bee}

certainty be known of the curious, profound, and intimate side of its inhabitants. Nor will this be at the cost of what still remains to be learned. I shall pass over in silence the hoary traditions that, in the country and many a book, still constitute the legend of the hive. Whenever there be doubt, disagreement, hypothesis, when I arrive at the unknown, I shall declare it loyally; you will find that we often shall halt before the unknown. Beyond the appreciable facts of their life we know but little of the bees. And the closer our acquaintance becomes, the nearer is our ignorance brought to us of the depths of their real existence; but such ignorance is better than the other kind, which is unconscious, and satisfied.

Does an analogous work on the bee exist? I believe I have read almost all that has been written on bees; but of 


\section{On the Threshold of the Hive}

kindred matter I know only Michelet's chapter at the end of his book "The Insect," and Ludwig Büchner's essay in his "Mind in Animals." Michelet merely hovers on the fringe of his subject; Büchner's treatise is comprehensive enough, but contains so many hazardous statements, so much long-discarded gossip and hearsay, that I suspect him of never having left his library, never having set forth himself to question his heroines, or opened one of the many hundreds of rustling, wing-lit hives which we must profane before our instinct can be attuned to their secret, before we can perceive the spirit and atmosphere, perfume and mystery, of these virgin daughters of toil. The book smells not of the bee, or its honey; and has the defects of many a learned work, whose conclusions often are preconceived, and whose scientific attainment is composed of a vast array of 


\section{The Life of the Bee}

doubtful anecdotes collected on every side. But in this essay of mine we rarely shall meet each other; for our startingpoint, our aim, and our point of view are all very different.

\section{[2]}

The bibliography of the bee (we will begin with the books so as to get rid of them as soon as we can and go to the source of the books) is very extensive. From the beginning this strange little creature, that lived in a society under complicated laws and executed prodigious labours in the darkness, attracted the notice of men. Aristotle, Cato, Varro, Pliny, Columella, Palladius all studied the bees; to say nothing of Aristomachus, who, according to Cicero, watched them for fifty-eight years, and of Phyliscus, whose writings are lost. But these dealt rather with the legend of the. 


\section{On the Threshold of the Hive}

bee; and all that we can gather therefrom - which indeed is exceedingly little - we may find condensed in the fourth book of Virgil's Georgics.

The real history of the bee begins in the seventeenth century, with the discoveries of the great Dutch savant Swammerdam. It is well, however, to add this detail, but little known: before Swammerdam a Flemish naturalist named Clutius had arrived at certain important truths, such as the sole maternity of the queen and her possession of the attributes of both sexes, but he had left these unproved. Swammerdam founded the true methods of scientific investigation; he invented the microscope, contrived injections to ward off decay, was the first to dissect the bees, and by the discovery of the ovaries and the oviduct definitely fixed the sex of the queen, hitherto looked upon as a king, and threw the whole 


\section{The Life of the Bee}

political scheme of the hive into most. unexpected light by basing it upon maternity. Finally he produced woodcuts and engravings so perfect that to this day they serve to illustrate many books on apiculture. $\mathrm{He}$ lived in the turbulent, restless Amsterdam of those days, regretting "Het Zoete Buiten Leve" - The Sweet Life of the Country - and died, wornout with work, at the age of forty-three. $\mathrm{He}$ wrote in a pious, formal style, with beautiful, simple outbursts of a faith that, fearful of falling away, ascribed all things to the glory of the Creator; and embodied his observations and studies in his great work "Bybel der Natuure," which the doctor Boerhave, a century later, caused to be translated from the Dutch into Latin under the title of "Biblia Naturæ." (Leyden, I737.)

Then came Réaumur, who, pursuing similar methods, made a vast number of 


\section{On the Threshold of the Hive}

curious experiments and researches in his gardens at Charenton, and devoted to the bees an entire volume of his "Notes to Serve for a History of Insects." One may read it with profit to-day, and without fatigue. It is clear, direct, and sincere, and possessed of a certain hard, arid charm of its own. He sought especially the destruction of ancient errors; he himself was responsible for several new ones; he partially understood the formation of swarms and the political establishment of queens; in a word, he discovered many difficult truths, and paved the way for the discovery of more. He fully appreciated the marvellous architecture of the hive; and what he said on the subject has never been better said. It is to him, too, that we owe the idea of the glass hives, which, having since been perfected, enable us to follow the entire private life of these fierce insects, whose 


\section{The Life of the Bee}

work, begun in the dazzling sunshine, receives its crown in the darkness. To be comprehensive, one should mention also the somewhat subsequent works and investigations of Charles Bonnet and Schirach (who solved the enigma of the royal egg); but I will keep to the broad lines, and pass at once to François Huber, the master and classic of contemporary apiarian science.

Huber was born in Geneva in $175^{\circ}$, and fell blind in his earliest youth. The experiments of Réaumur interested him; he sought to verify them, and soon becoming passionately absorbed in these researches, eventually, with the assistance of an intelligent and faithful servant, François Burnens, devoted his entire life to the study of the bee. In the annals of human suffering and human triumph there is nothing more touching, no lesson more admirable, than the story of this 


\section{On the Threshold of the Hive}

patient collaboration, wherein the one who saw only with immaterial light guided with his spirit the eyes and hands of the other who had the real earthly vision; where he who, as we are assured, had never with his own eyes beheld a comb of honey, was yet able, notwithstanding the veil on his dead eyes that rendered double the veil in which nature enwraps all things, to penetrate the profound secrets of the genius that had made this invisible comb; as though to teach us that no condition in life can warrant our abandoning our desire and search for the truth. I will not enumerate all that apiarian science owes to Huber; to state what it does not owe were the briefer task. His "New Observations on Bees," of which the first volume was written in 1789 , in the form of letters to Charles Bonnet, the second not appearing till twenty years later, have remained the 


\section{The Life of the Bee}

unfailing, abundant treasure into which every subsequent writer has dipped. And though a few mistakes may be found therein, a few incomplete truths; though since his time considerable additions have been made to the micrography and practical culture of bees, the handling of queens, etc., there is not a single one of his principal statements that has been disproved, or discovered in error; and in our actual experience they stand untouched, and indeed at its very foundation.

\section{[3]}

Some years of silence followed these revelations; but soon a German clergyman, Dzierzon, discovered parthenogenesis, i. e. the virginal parturition of queens, and contrived the first hive with movable combs, thereby enabling the bee-keeper henceforth to take his share of the harvest 


\section{On the Threshold of the Hive}

of honey, without being forced to destroy his best colonies and in one instant annihilate the work of an entire year. This hive, still very imperfect, received masterly improvement at the hands of Langstroth, who invented the movable frame properly so called, which has been adopted in America with extraordinary success. Root, Quinby, Dadant, Cheshire, De Layens, Cowan, Heddon, Howard, etc., added still further and precious improvement. Then it occurred to Mehring that if bees were supplied with combs that had an artificial waxen foundation, they would be spared the labour of fashioning the wax and constructing the cells, which costs them much honey and the best part of their time; he found that the bees accepted these combs most readily, and adapted them to their requirements.

Major de Hruschka invented the Honey- 


\section{The Life of the Bee}

Extractor, which enables the honey to be withdrawn by centrifugal force without breaking the combs, etc. And thus, in a few years, the methods of apiculture underwent a radical change. The capacity and fruitfulness of the hives were trebled. Great and productive apiaries arose on every side. An end was put to the useless destruction of the most industrious cities, and to the odious selection of the least fit which was its result. Man truly became the master of the bees, although furtively, and without their knowledge; directing all things without giving an order, receiving obedience but not recognition. For the destiny once imposed by the seasons he has substituted his will. He repairs the injustice of the year, unites hostile republics, and equalises wealth. $\mathrm{He}$ restricts or augments the births, regulates the fecundity of the queen, dethrones her and instals another 


\section{On the Threshold of the Hive}

in her place, after dexterously obtaining the reluctant consent of a people who would be maddened at the mere suspicion of an inconceivable intervention. When he thinks fit, he will peacefully violate the secret of the sacred chambers, and the elaborate, tortuous policy of the palace. He will five or six times in succession deprive the bees of the fruit of their labour, without harming them, without their becoming discouraged or even impoverished. $\mathrm{He}$ proportions the store-houses and granaries of their dwellings to the harvest of flowers that the spring is spreading over the dip of the hills. He compels them to reduce the extravagant number of lovers who await the birth of the royal princesses. In a word he does with them what he will, he obtains what he will, provided always that what he seeks be in accordance with their laws and their virtues; for beyond all the desires of this strange 


\section{The Life of the Bee}

god who has taken possession of them. who is too vast to be seen and too alien to be understood, their eyes see further than the eyes of the god himself; and their one thought is the accomplishment, with untiring sacrifice, of the mysterious duty of their race.

$$
\text { [4] }
$$

Let us now, having learned from books all that they had to teach us of a very ancient history, leave the science others have acquired and look at the bees with our own eyes. An hour spent in the midst of the apiary will be less instructive, perhaps; but the things we shall see will be infinitely more stimulating and more actual,

I have not yet forgotten the first apiary I saw, where I learned to love the bees. It was many years ago, in a large village of Dutch Flanders, the sweet and pleasant 


\section{On the Threshold of the Hive}

country whose love for brilliant colour rivals that of Zealand even, the concave mirror of Holland; a country that gladly spreads out before us, as so many pretty, thoughtful toys, her illuminated gables, and waggons, and towers; her cupboards and clocks that gleam at the end of the passage; her little trees marshalled in line along quays and canal-banks, waiting, one almost might think, for some quiet, beneficent ceremony; her boats and her barges with sculptured poops, her flower-like doors and windows, immaculate dams, and elaborate, many-coloured drawbridges; and her little varnished houses, bright as new pottery, from which bell-shaped dames come forth, all a-glitter with silver and gold, to milk the cows in the whitehedged fields, or spread the linen on flowery lawns, cut into patterns of oval and lozenge, and most astoundingly green. 


\section{The Life of the Bee}

To this spot, where life would seem more restricted than elsewhere - if it be possible for life indeed to become restricted - a sort of aged philosopher had retired; an old man somewhat akin to Virgil's -

"Man equal to kings, and approaching the gods ;" whereto Lafontaine might have added, "And, like the gods, content and at rest."

Here had he built his refuge, being a little weary; not disgusted, for the large aversions are unknown to the sage; but a little weary of interrogating men, whose answers to the only interesting questions one can put concerning nature and her veritable laws are far less simple than those that are given by animals and plants. His happiness, like the Scythian philosopher's, lay all in the beauties of his garden; and best-loved and visited most often, was the apiary, composed of 


\section{On the Threshold of the Hive}

twelve domes of straw, some of which he had painted a bright pink, and some a clear yellow, but most of all a tender blue; having noticed, long before Sir John Lubbock's demonstrations, the bees' fondness for this colour.

These hives stood against the wall of the house, in the angle formed by one of those pleasant and graceful Dutch kitchens whose earthenware dresser, all bright with copper and tin, reflected itself through the open door on to the peaceful canal. And the water, burdened with these familiar images beneath its curtain of poplars, led one's eyes to a calm horizon of mills and of meadows.

Here, as in all places, the hives lent a new meaning to the flowers and the silence, the balm of the air and the rays of the sun. One seemed to have drawn very near to the festival spirit of nature. One was content to rest at this radiant cross- 


\section{The Life of the Bee}

road, where the aerial ways converge and divide that the busy and tuneful bearers of all country perfumes unceasingly travel from dawn unto dusk. One heard the musical voice of the garden, whose loveliest hours revealed their rejoicing soul and sang of their gladness. One came hither, to the school of the bees, to be taught the preoccupations of all-powerful nature, the harmonious concord of the three kingdoms, the indefatigable organisation of life, and the lesson of ardent and disinterested work; and another lesson too, with a moral as good, that the heroic workers taught there, and emphasised, as it were, with the fiery darts of their myriad wings, was to appreciate the somewhat vague savour of leisure, to enjoy the almost unspeakable delights of those immaculate days that revolved on themselves in the fields of space, forming merely a transparent globe, as 
On the Threshold of the Hive void of memory as the happiness without alloy.

\section{[ 5 ]}

In order to follow, as simply as possible, the life of the bees through the year, we will take a hive that awakes in the spring and duly starts on its labours; and then we shall meet, in their natural order, all the great episodes, viz.: the formation and departure of the swarm, the foundation of the new city, the birth, combat and nuptial flight of the young queens, the massacre of the males, and finally, the return of the sleep of winter. With each of these episodes there will go the necessary explanations as to the laws, habits, peculiarities and events that produce and accompany it; so that, when arrived at the end of the bee's short year, which extends only from April to the last days of September, we shall have gazed upon 


\section{The Life of the Bee}

all the mysteries of the palace of honey. Before we open it, therefore, and throw a general glance around, we only need say that the hive is composed of a queen, the mother of all her people; of thousands of workers or neuters who are incomplete and sterile females; and lastly of some hundreds of males, from whom one shall be chosen as the sole and unfortunate consort of the queen that the workers will elect in the future, after the more or less voluntary departure of the reigning mother.

\section{[6]}

The first time that we open a hive there comes over us an emotion akin to that we might feel at profaning some unknown object, charged perhaps with dreadful surprise, as a tomb. A legend of menace and peril still clings to the bees. There is the distressful recollection of her sting, 


\section{On the Threshold of the Hive}

which produces a pain so characteristic that one knows not wherewith to compare it; a kind of destroying dryness, a flame of the desert rushing over the wounded limb, as though these daughters of the sun had distilled a dazzling poison from their father's angry rays, in order more effectively to defend the treasure they gather from his beneficent hours.

It is true that were some one who neither knows nor respects the customs and character of the bee suddenly to fling open the hive, it would turn at once into a burning bush of heroism and anger; but the slight amount of skill needed to handle it with impunity can be most readily acquired. Let but a little smoke be deftly applied, much coolness and gentleness be shown, and our well-armed workers will suffer themselves to be despoiled without dreaming of drawing their sting. It is not the fact, as some 


\section{The Life of the Bee}

have maintained, that the bees recognise their master; nor have they any fear of man; but at the smell of the smoke, at the large slow gestures that traverse their dwellings without threatening them, they imagine that this is not the attack of an enemy against whom defence is possible, but that it is a force or a natural catastrophe whereto they do well to submit.

Instead of vainly struggling, therefore, they do what they can to safeguard the future; and, obeying a foresight that for once is in error, they fly to their reserves of honey, into which they eagerly dip in order to possess within themselves the wherewithal to start a new city, immediately and no matter where, should the ancient one be destroyed or they be compelled to forsake it. 


\section{On the Threshold of the Hive}

\section{[ 7 ]}

The first impression of the novice before whom an observation-hive ${ }^{1}$ is opened will be one of some disappointment. He had been told that this little glass case contained an unparalleled activity, an infinite number of wise laws, and a startling amalgam of mystery, experience, genius, calculation, science, of various industries, of certitude and prescience, of intelligent habits and curious feelings and virtues. All that he sees is a confused mass of little reddish groups,

1 By observation-hive is meant a hive of glass, furnished with black curtains or shutters. The best kind have only one comb, thus permitting both faces to be studied. These hives can be placed in a drawing-room, library, etc., without inconvenience or danger. The bees that inhabit the one I have in $m y$ study in Paris are able even in the stony desert of that great city, to find the wherewithal to nourish themselves and to prosper. 


\section{The Life of the Bee}

somewhat resembling roasted coffee-berries, or bunches of raisins piled against the glass. They look more dead than alive; their movements are slow, incoherent, and incomprehensible: Can these be the wonderful drops of light he had seen but a moment ago, unceasingly flashing and sparkling, as they darted among the pearls and the gold of a thousand wide-open calyces?

They appear to be shivering in the darkness, to be numbed, suffocated, so closely are they huddled together; one might fancy they were ailing captives, or queens dethroned, who have had their one moment of glory in the midst of their radiant garden, and are now compelled to return to the shameful squalor of their poor overcrowded home.

It is with them as with all that is deeply real; they must be studied, and one must learn how to study them. The 


\section{On the Threshold of the Hive}

inhabitant of another planet who should see men and women coming and going almost imperceptibly through our streets, crowding at certain times around certain buildings, or waiting for one knows not what, without apparent movement, in the depths of their dwellings, might conclude therefrom that they, too, were miserable and inert. It takes time to distinguish the manifold activity contained in this inertia.

And indeed every one of the little almost motionless groups in the hive is incessantly working, each at a different trade. Repose is unknown to any; and such, for instance, as seem the most torpid, as they hang in dead clusters against the glass, are intrusted with the most mysterious and fatiguing task of all : it is they who secrete and form the wax. But the details of this universal activity will be given in their place. For the mo- 


\section{The Life of the Bee}

ment we need only call attention to the essential trait in the nature of the bee which accounts for the extraordinary agglomeration of the various workers. The bee is above all, and even to a greater extent than the ant, a creature of the crowd. She can live only in the midst of a multitude. When she leaves the hive, which is so densely packed that she has to force her way with blows of her head through the living walls that enclose her, she departs from her proper element. She will dive for an instant into flower-filled space, as the swimmer will dive into the sea that is filled with pearls, but under pain of death it behoves her at regular intervals to return and breathe the crowd as the swimmer must return and breathe the air. Isolate her, and however abundant the food or favourable the temperature, she will expire in a few days not of hunger 


\section{On the Threshold of the Hive}

or cold, but of loneliness. From the crowd, from the city, she derives an invisible aliment that is as necessary to her as honey. This craving will help to explain the spirit of the laws of the hive. For in them the individual is nothing, her existence conditional only, and herself, for one indifferent moment, a winged organ of the race. Her whole life is an entire sacrifice to the manifold, everlasting being whereof she forms part. It is strange to note that it was not always so. We find even to-day, among the melliferous hymenoptera, all the stages of progressive civilisation of our own domestic bee. At the bottom of the scale we find her working alone, in wretchedness, often not seeing her offspring (the Prosopis, the Colletes, etc.); sometimes living in the midst of the limited family that she produces annually (as in the case of the humble-bee). Then she 


\section{The Life of the Bee}

forms temporary associations (the Panurgi, the Dasypodœ, the Hacliti, etc.) and at last we arrive, through successive stages, at the almost perfect but pitiless society of our hives, where the individual is entirely merged in the republic, and the republic in its turn invariably sacrificed to the abstract and immortal city of the future.

$$
\text { [8] }
$$

Let us not too hastily deduce from these facts conclusions that apply to man. $\mathrm{He}$ possesses the power of withstanding certain of nature's laws; and to know whether such resistance be right or wrong is the gravest and obscurest point in his morality. But it is deeply interesting to discover what the will of nature may be in a different world; and this will is revealed with extraordinary clearness in the evolution of the hymenoptera, which, 


\section{On the Threshold of the Hive}

of all the inhabitants of this globe, possess the highest degree of intellect after that of man. The aim of nature is manifestly the improvement of the race; but no less manifest is her inability, or refusal, to obtain such improvement except at the cost of the liberty, the rights, and the happiness of the individual. In proportion as a society organises itself, and rises in the scale, so does a shrinkage enter the private life of each one of its members. Where there is progress, it is the result only of a more and more complete sacrifice of the individual to the general interest. Each one is compelled, first of all, to renounce his vices, which are acts of independence. For instance, at the last stage but one of apiarian civilisation, we find the humblebees, which are like our cannibals. The adult workers are incessantly hovering around the eggs, which they seek to 


\section{The Life of the Bee}

devour, and the mother has to display the utmost stubbornness in their defence. Then having freed himself from his most dangerous vices, each individual has to acquire a certain number of more and more painful virtues. Among the humblebees, for instance, the workers do not dream of renouncing love, whereas our domestic bee lives in a state of perpetual chastity. And indeed we soon shall show how much more she has to abandon, in exchange for the comfort and security of the hive, for its architectural, economic, and political perfection; and we shall return to the evolution of the hymenoptera in the chapter devoted to the progress of the species. 


\section{II}

THE SWARM 



\section{II}

\section{THE SWARM}

\section{[9]}

W ${ }^{\mathrm{E}}$ will now, so as to draw more closely to nature, consider the different episodes of the swarm as they come to pass in an ordinary hive, which is ten or twenty times more populous than an observation one, and leaves the bees entirely free and untrammelled.

Here, then, they have shaken off the torpor of winter. The queen started laying again in the very first days of February, and the workers have flocked to the willows and nut-trees, gorse and violets, anemones and lungworts. Then spring invades the earth, and cellar and stream with honey and pollen, while each 


\section{The Life of the Bee}

day beholds the birth of thousands of bees. The overgrown males now all sally forth from their cells, and disport themselves on the combs; and so crowded does the too prosperous city become that hundreds of belated workers, coming back from the flowers towards evening, will vainly seek shelter within, and will be forced to spend the night on the threshold, where they will be decimated by the cold.

Restlessness seizes the people, and the old queen begins to stir. She feels that a new destiny is being prepared. She has religiously fulfilled her duty as a good creatress; and from this duty done there result only tribulation and sorrow. An invincible power menaces her tranquillity; she will soon be forced to quit this city of hers, where she has reigned. But this city is her work, it is she, herself. She is not its queen in the sense in which men use the word. She issues no 


\section{The Swarm}

orders; she obeys, as meekly as the humblest of her subjects, the masked power, sovereignly wise, that for the present, and till we attempt to locate it, we will term the "spirit of the hive." But she is the unique organ of love; she is the mother of the city. She founded it amid uncertainty and poverty. She has peopled it with her own substance; and all who move within its walls workers, males, larva, nymphs, and the young princesses whose approaching birth will hasten her own departure, one of them being already designed as her successor by the "spirit of the hive"all these have issued from her flanks.

$$
\text { [ } 10 \text { ] }
$$

What is this "spirit of the hive"where does it reside? It is not like the special instinct that teaches the bird to construct its well planned nest, and then 


\section{The Life of the Bee}

seek other skies when the day for migration returns. Nor is it a kind of mechanical habit of the race, or blind craving for life, that will fling the bees upon any wild hazard the moment an unforeseen event shall derange the accustomed order of phenomena. On the contrary, be the event never so masterful, the "spirit of the hive" still will follow it, step by step, like an alert and quickwitted slave, who is able to derive advantage even from his master's most dangerous orders.

It disposes pitilessly of the wealth and the happiness, the liberty and life, of all this winged people; and yet with discretion, as though governed itself by some great duty. It regulates day by day the number of births, and contrives that these shall strictly accord with the number of flowers that brighten the country-side. It decrees the queen's deposition or warns 


\section{The Swarm}

her that she must depart; it compels her to bring her own rivals into the world, and rears them royally, protecting them from their mother's political hatred. So, too, in accordance with the generosity of the flowers, the age of the spring, and the probable dangers of the nuptial flight, will it permit or forbid the first-born of the virgin princesses to slay in their cradles her younger sisters, who are singing the song of the queens. At other times, when the season wanes, and flowery hours grow shorter, it will command the workers themselves to slaughter the whole imperial brood, that the era of revolutions may close, and work become the sole object of all. The "spirit of the hive" is prudent and thrifty, but by no means parsimonious. And thus, aware, it would seem, that nature's laws are somewhat wild and extravagant in all that pertains to love, it tolerates, during summer days 


\section{The Life of the Bee}

of abundance, the embarrassing presence in the hive of three or four hundred males, from whose ranks the queen about to be born shall select her lover; three or four hundred foolish, clumsy, useless, noisy creatures, who are pretentious, gluttonous, dirty, coarse, totally and scandalously idle, insatiable, and enormous.

But after the queen's impregnation, when flowers begin to close sooner, and open later, the spirit one morning will coldly decree the simultaneous and general massacre of every male. It regulates the workers' labours, with due regard to their age; it allots their task to the nurses who tend the nymphs and the larvæ, the ladies of honour who wait on the queen and never allow her out of their sight; the house-bees who air, refresh, or heat the hive by fanning their wings, and hasten the evaporation of the honey that may be too highly charged with water; 


\section{The Swarm}

the architects, masons, wax-workers, and sculptors who form the chain and construct the combs; the foragers who sally forth to the flowers in search of the nectar that turns into honey, of the pollen that feeds the nymphs and the larva, the propolis that welds and strengthens the buildings of the city, or the water and salt required by the youth of the nation. Its orders have gone to the chemists who ensure the preservation of the honey by letting a drop of formic acid fall in from the end of their sting; to the capsulemakers who seal down the cells when the treasure is ripe, to the sweepers who maintain public places and streets most irreproachably clean, to the bearers whose duty it is to remove the corpses; and to the amazons of the guard who keep watch on the threshold by night and by day, question comers and goers, recognise the novices who return from their very 


\section{The Life of the Bee}

first flight, scare away vagabonds, marauders and loiterers, expel all intruders, attack redoubtable foes in a body, and, if need be, barricade the entrance.

Finally, it is the spirit of the hive that fixes the hour of the great annual sacrifice to the genius of the race: the hour, that is, of the swarm; when we find a whole people, who have attained the topmost pinnacle of prosperity and power, suddenly abandoning to the generation to come their wealth and their palaces, their homes and the fruits of their labour; themselves content to encounter the hardships and perils of a new and distant country. This act, be it conscious or not, undoubtedly passes the limits of human morality. Its result will sometimes be ruin, but poverty always; and the thrice-happy city is scattered abroad in obedience to a law superior to its own happiness. Where has this law been decreed, which, 


\section{The Swarm}

as we soon shall find, is by no means as blind and inevitable as one might believe? Where, in what assembly, what council, what intellectual and moral sphere, does this spirit reside to whom all must submit, itself being vassal to an heroic duty, to an intelligence whose eyes are persistently fixed on the future?

It comes to pass with the bees as with most of the things in this world; we remark some few of their habits; we say they do this, they work in such and such fashion, their queens are born thus, their workers are virgin, they swarm at a certain time. And then we imagine we know them, and ask nothing more. We watch them hasten from flower to flower, we see the constant agitation within the hive; their life seems very simple to us, and bounded, like every life, by the instinctive cares of reproduction and nourishment. But let the eye draw near, and 


\section{The Life of the Bee}

endeavour to see; and at once the least phenomenon of all becomes overpoweringly complex; we are confronted by the enigma of intellect, of destiny, will, aim, means, causes; the incomprehensible organisation of the most insignificant act of life.

\section{[ I I ]}

Our hive, then, is preparing to swarm; making ready for the great immolation to the exacting gods of the race. In obedience to the order of the spirit - an order that to us may well seem incomprehensible, for it is entirely opposed to all our own instincts and feelings $-60,000$ or 70,000 bees out of the 80,000 or 90,000 that form the whole population, will abandon the maternal city at the prescribed hour. They will not leave at a moment of despair; or desert, with sudden and wild resolve, a home laid waste by famine, 


\section{The Swarm}

disease, or war. No, the exile has long been planned, and the favourable hour patiently awaited. Were the hive poor, had it suffered from pillage or storm, had misfortune befallen the royal family, the bees would not forsake it. They leave it only when it has attained the apogee of its prosperity; at a time when, after the arduous labours of the spring, the immense palace of wax has its 120,000 wellarranged cells overflowing with new honey, and with the many-coloured flour, known as "bees' bread," on which nymphs and larvæ are fed.

Never is the hive more beautiful than on the eve of its heroic renouncement, in its unrivalled hour of fullest abundance and joy; serene for all its apparent excitement and feverishness.

Let us endeavour to picture it to ourselves, not as it appears to the bees, - for we cannot tell in what magical, formidable 


\section{The Life of the Bee}

fashion things may be reflected in the 6,000 or 7,000 facets of their lateral eyes and the triple cyclopean eye on their brow, - but as it would seem to us, were we of their stature. From the height of a dome more colossal than that of St. Peter's at Rome waxen walls descend to the ground, balanced in the void and the darkness; gigantic and manifold, vertical and parallel geometric constructions, to which, for relative precision, audacity, and vastness, no human structure is comparable. Each of these walls, whose substance still is immaculate and fragrant, of virginal, silvery freshness, contains thousands of cells, that are stored with provisions sufficient to feed the whole people for several weeks. Here, lodged in transparent cells, are the pollens, love-ferment of every flower of spring, making brilliant splashes of red and yellow, of black and mauve. Close by, in twenty thousand - reservoirs, sealed with a seal 


\section{The Swarm}

that shall only be broken on days of supreme distress, the honey of April is stored, most limpid and perfumed of all, wrapped round with long and magnificent embroidery of gold, whose borders hang stiff and rigid. Still lower the honey of May matures, in great open vats, by whose side watchful cohorts maintain an incessant current of air. In the centre, and far from the light whose diamond rays steal in through the only opening, in the warmest part of the hive, there stands the abode of the future; here does it sleep, and wake. For this is the royal domain of the brood-cells, set apart for the queen and her acolytes; about 10,000 cells wherein the eggs repose, 15,000 or 16,000 chambers tenanted by larvæ, 40,000 dwellings inhabited by white nymphs to whom thousands of nurses minister. ${ }^{1}$ And fin-

1 The figures given here are scrupulously exact. They are those of a well-filled hive in full prosperity. 


\section{The Life of the Bee}

ally, in the holy of holies of these parts, are the three, four, six, or twelve sealed palaces, vast in size compared with the others, where the adolescent princesses lie who await their hour, wrapped in a kind of shroud, all of them motionless and pale, and fed in the darkness.

$$
\text { [. } 12 \text { ] }
$$

On the day, then, that the Spirit of the Hive has ordained, a certain part of the population will go forth, selected in accordance with sure and immovable laws, and make way for hopes that as yet are formless. In the sleeping city there remain the males, from whose ranks the royal lover shall come, the very young bees that tend the brood-cells, and some thousands of workers who continue to forage abroad, to guard the accumulated treasure, and preserve the moral traditions of the hive. For each hivo 


\section{The Swarm}

has its own code of morals. There are some that are very virtuous and some that are very perverse; and a careless bee-keeper will often corrupt his people, destroy their respect for the property of others, incite them to pillage, and induce in them habits of conquest and idleness which will render them sources of danger to all the little republics around. These things result from the bee's discovery that work among distant flowers, whereof many hundreds must be visited to form one drop of honey, is not the only or promptest method of acquiring wealth, but that it is easier to enter ill-guarded cities by stratagem, or force her way into others too weak for self-defence. Nor is it easy to restore to the paths of duty a hive that has become thus depraved. 


\section{The Life of the Bee}

\section{[ I3 ]}

All things go to prove that it is not the queen, but the spirit of the hive, that decides on the swarm. With this queen of ours it happens as with many a chief among men, who though he appear to give orders, is himself obliged to obey commands far more mysterious, far more inexplicable, than those he issues to his subordinates. The hour once fixed, the spirit will probably let it be known at break of dawn, or the previous night, if indeed not two nights before; for scarcely has the sun drunk in the first drops of dew when a most unaccustomed stir, whose meaning the bee-keeper rarely will fail to grasp, is to be noticed within and around the buzzing city. At times one would almost appear to detect a sign of dispute, hesitation, recoil. It will happen even 


\section{The Swarm}

that for day after day a strange emotion, apparently without cause, will appear and vanish in this transparent, golden throng. Has a cloud that we cannot see crept across the sky that the bees are watching; or is their intellect battling with a new regret? Does a winged council debate the necessity of the departure? Of this we know nothing; as we know nothing of the manner in which the spirit conveys its resolution to the crowd. Certain as it may seem that the bees communicate with each other, we know not whether this be done in human fashion. It is possible even that their own refrain may be inaudible to them: the murmur that comes to us heavily laden with perfume of honey, the ecstatic whisper of fairest summer days that the bee-keeper loves so well, the festival song of labour that rises and falls around the hive in the crystal of the hour, and might almost be the 


\section{The Life of the Bee}

chant of the eager flowers, hymn of their gladness and echo of their soft fragrance, the voice of the white carnations, the marjoram, and the thyme. They have, however, a whole gamut of sounds that we can distinguish, ranging from profound delight to menace, distress, and anger; they have the ode of the queen, the song of abundance, the psalms of grief, and, lastly, the long and mysterious war-cries the adolescent princesses send forth during the combats and massacres that precede the nuptial flight. May this be a fortuitous music that fails to attain their inward silence? In any event they seem not the least disturbed at the noises we make near the hive; but they regard these perhaps as not of their world, and possessed of no interest for them. It is possible that we on our side hear only a fractional part of the sounds that the bees produce, and that they have many 


\section{The Swarm}

harmonies to which our ears are not attuned. We soon shall see with what startling rapidity they are able to understand each other, and adopt concerted measures, when, for instance, the great honey thief, the huge sphinx atropos, the sinister butterfly that bears a death's head on its back, penetrates into the hive, humming its own strange note, which acts as a kind of irresistible incantation; the news spreads quickly from group to group, and from the guards at the threshold to the workers on the furthest combs, the whole population quivers.

$$
\text { [14] }
$$

It was for a long time believed that when these wise bees, generally so prudent, so far-sighted and economical, abandoned the treasures of their kingdom and flung themselves upon the uncertainties of life, they were yielding to a kind of 


\section{The Life of the Bee}

irresistible folly, a mechanical impulse, a law of the species, a decree of nature, or to the force that for all creatures lies hidden in the revolution of time. It is our habit, in the case of the bees no less than our own, to regard as fatality all that we do not as yet understand. But now that the hive has surrendered two or three of its material secrets, we have discovered that this exodus is neither instinctive nor inevitable. It is not a blind emigration, but apparently the well-considered sacrifice of the present generation in favour of the generation to come. The bee-keeper has only to destroy in their cells the young queens that still are inert, and, at the same time, if nymphs and larvæ abound, to enlarge the store-houses and dormitories of the nation, for this unprofitable tumult instantaneously to subside, for work to be at once resumed, and the flowers revisited; while the old queen, who now is 


\section{The Swarm}

essential again, with no successor to hope for, or perhaps to fear, will renounce for this year her desire for the light of the sun. Reassured as to the future of the activity that will soon spring into life, she will tranquilly resume her maternal labours, which consist in the laying of two or three thousand eggs a day, as she passes, in a methodical spiral, from cell to cell, omitting none; and never pausing to rest.

Where is the fatality here, save in the love of the race of to-day for the race of to-morrow? This fatality exists in the human species also, but its extent and power seem infinitely less. Among men it never gives rise to sacrifices as great, as unanimous, or as complete. What farseeing fatality, taking the place of this one, do we ourselves obey? We know not; as we know not the being who watches us as we watch the bees. 


\section{The Life of the Bee}

$$
\text { [ 15 ] }
$$

But the hive that we have selected is disturbed in its history by no interference of man; and as the beautiful day advances with radiant and tranquil steps beneath the trees, its ardour, still bathed in dew, makes the appointed hour seem laggard. Over the whole surface of the golden corridors that divide the parallel walls the workers are busily making preparation for the journey. And each one will first of all burden herself with provision of honey sufficient for five or six days. From this honey that they bear within them they will distil, by a chemical process still unexplained, the wax required for the immediate construction of buildings. They will provide themselves also with a certain amount of propolis, a kind of resin with which they will seal all the crevices in the new dwelling, strengthen weak places, varnish the 


\section{The Swarm}

walls, and exclude the light; for the bees love to work in almost total obscurity, guiding themselves with their many-faceted eyes, or with their antennæ perhaps, the seat, it would seem, of an unknown sense that fathoms and measures the darkness.

$$
\text { [ 16] }
$$

They are not without prescience, therefore, of what is to befall them on this the most dangerous day of all their existence. Absorbed by the cares, the prodigious perils of this mighty adventure, they will have no time now to visit the gardens and meadows; and to-morrow, and after tomorrow, it may happen that rain may fall, or there may be wind; that their wings may be frozen or the flowers refuse to open. Famine and death would await them were it not for this foresight of theirs. None would come to their help, nor would they seek help of any. For 


\section{The Life of the Bee}

one city knows not the other, and assistance never is given. And even though the bee-keeper deposit the hive, in which he has gathered the old queen and her attendant cluster of bees, by the side of the abode they have but this moment quitted, they would seem, be the disaster never so great that shall now have befallen them, to have wholly forgotten the peace and the happy activity that once they had known there, the abundant wealth and the safety that had then been their portion; and all, one by one, and down to the last of them, will perish of hunger and cold around their unfortunate queen rather than return to the home of their birth, whose sweet odour of plenty, the fragrance, indeed, of their own past assiduous labour, reaches them even in their distress. 


\section{The Swarm}

$$
\text { [17 ] }
$$

That is a thing, some will say, that men would not do, - a proof that the bee, notwithstanding the marvels of its organisation, still is lacking in intellect and veritable consciousness. Is this so certain? Other beings, surely, may possess an intellect that differs from ours, and produces different results, without therefore being inferior. And besides, are we, even in this little human parish of ours, such infallible judges of matters that pertain to the spirit? Can we so readily divine the thoughts that may govern the two or three people we may chance to see moving and talking behind a closed window, when their words do not reach us? Or let us suppose that an inhabitant of Venus or Mars were to contemplate us from the height of a mountain, and watch the little black specks that we form in 


\section{The Life of the Bee}

space, as we come and go in the streets and squares of our towns. Would the mere sight of our movements, our buildings, machines, and canals, convey to him any precise idea of our morality, intellect, our manner of thinking, and loving, and hoping, - in a word, of our real and intimate self? All he could do, like ourselves when we gaze at the hive, would be to take note of some facts that seem very surprising; and from these facts to deduce conclusions probably no less erroneous, no less uncertain, than those that we choose to form concerning the bee.

This much at least is certain; our " little black specks" would not reveal the vast moral direction, the wonderful unity, that are so apparent in the hive. "Whither do they tend, and what is it they do?" he would ask, after years and centuries of patient watching. "What is the aim of their life, or its pivot? Do they obey 


\section{The Swarm}

some God? I can see nothing that governs their actions. The little things that one day they appear to collect and build up, the next they destroy and scatter. They come and they go, they meet and disperse, but one knows not what it is they seek. In numberless cases the spectacle. they present is altogether inexplicable. There are some, for instance, who, as it were, seem scarcely to stir from their place. They are to be distinguished by their glossier coat, and often too by their more considerable bulk. They occupy buildings ten or twenty times larger than ordinary dwellings, and richer, and more ingeniously fashioned. Every day they spend many hours at their meals, which sometimes indeed are prolonged far into the night. They appear to be held in extraordinary honour by those who approach them; men come from the neighbouring houses, bringing provisions, 


\section{The Life of the Bee}

and even from the depths of the country, laden with presents. One can only assume that these persons must be indispensable to the race, to which they render essential service, although our means of investigation have not yet enabled us to discover what the precise nature of this service may be. There are others, again, who are incessantly engaged in the most wearisome labour, whether it be in great sheds full of wheels that forever turn round and round, or close by the shipping, or in obscure hovels, or on small plots of earth that from sunrise to sunset they are constantly delving and digging. We are led to believe that this labour must be an offence, and punishable. For the persons guilty of it are housed in filthy, ruinous, squalid cabins. They are clothed in some colourless hide. So great does their ardour appear for this noxious, or at any rate useless activity, that they scarcely allow 


\section{The Swarm}

themselves time to eat or to sleep. In numbers they are to the others as a thousand to one. It is remarkable that the species should have been able to survive to this day under conditions so unfavourable to its development. It should be mentioned, however, that apart from this characteristic devotion to their wearisome toil, they appear inoffensive and docile; and satisfied with the leavings of those who evidently are the guardians, if not the saviours, of the race."

$$
\text { [ } 18 \text { ] }
$$

Is it not strange that the hive, which we vaguely survey from the height of another world, should provide our first questioning glance with so sure and profound a reply? Must we not admire the manner in which the thought or the god that the bees obey is at once revealed by their edifices, wrought, with such striking 


\section{The Life of the Bee}

conviction, by their customs and laws, their political and economical organisation, their virtues, and even their cruelties? Nor is this god, though it be perhaps the only one to which man has as yet never offered serious worship, by any means the least reasonable or the least legitimate that we can conceive. The god of the bees is the future. When we, in our study of human history, endeavour to gauge the moral force or greatness of a people or race, we have but one standard of measurement - the dignity and permanence of their ideal, and the abnegation wherewith they pursue it. Have we often encountered an ideal more conformable to the desires of the universe, more widely manifest, more disinterested or sublime: have we often discovered an abnegation more complete and heroic? 


\section{The Swarm}

$$
\text { [ } 19 \text { ] }
$$

Strange little republic, that, for all its logic and gravity, its matured conviction and prudence, still falls victim to so vast and precarious a dream! Who shall tell us, O little people that are so profoundly in earnest, that have fed on the warmth and the light and on nature's purest, the soul of the flowers, wherein matter for once seems to smile, and put forth itg most wistful effort towards beauty and hap. piness, - who shall tell. us what problems you have resolved, but we not yet, what certitudes you have acquired that we still have to conquer? And if you have truly resolved these problems, and acquired these certitudes, by the aid of some blind and primitive impulse and not through the intellect, then to what enigma, more insoluble still, are you not urging us on? Little city abounding 


\section{The Life of the Bee}

in faith and mystery and hope, why do your myriad virgins consent to a task that no human slave has ever accepted? Another spring might be theirs, another summer, were they only a little less wasteful of strength, a little less self-forgetful in their ardour for toil; but at the magnificent moment when the flowers all cry to them, they seem to be stricken with the fatal ecstasy of work; and in less than five weeks they almost all perish, their wings broken, their bodies shrivelled and covered with wounds.

"Tantus amor florum, et generandi gloria mellis!"

cries Virgil in the fourth book of the Georgics, wherein he devotes himself to the bees, and hands down to us the charming errors of the ancients, who looked on nature with eyes still dazzled by the presence of imaginary gods. 


\section{The Swarm}

$$
\text { [20] }
$$

Why do they thus renounce sleep, the delights of honey and love, and the exquisite leisure enjoyed, for instance, by their winged brother, the butterfly? Why will they not live as he lives? It is not hunger that urges them on. Two or three flowers suffice for their nourishment, and in one hour they wili visit two or three hundred, to collect a treasure whose sweetness they never will taste. Why all this toil and distress, and whence comes this mighty assurance? Is it so certain, then, that the new generation whereunto you offer your lives will merit the sacrifice; will be more beautiful, happier, will do something you have not done? Your aim is clear to us, clearer far than our own; you desire to live, as long as the world itself, in those that come after; but what can the aim be 


\section{The Life of the Bee}

of this great aim; what the mission of this existence eternally renewed?

And yet may it not be that these questions are idle, and we who are putting them to you mere childish dreamers, hedged round with error and doubt? And, indeed, had successive evolutions installed you all-powerful and supremely happy; had you gained the last heights, whence at length you ruled over nature's laws; nay, were you immortal goddesses, we still should be asking you what your desires might be, your ideas of progress; still wondering where you imagined that at last you would rest and declare your wishes fulfilled. We are so made that nothing contents us; that we can regard no single thing as having its aim self-contained, as simply existing, with no thought beyond existence. Has there been, to this day, one god out of all the multitude man has conceived, from 


\section{The Swarm}

the vulgarest to the most thoughtful, of whom it has not been required that he shall be active and stirring, that he shall create countless beings and things, and have myriad aims outside himself? And will the time ever come when we shall be resigned for a few hours tranquilly to represent in this world an interesting form of material activity; and then, our few hours over, to assume, without surprise and without regret, that other form which is the unconscious, the unknown, the slumbering, and the eternal?

$$
\text { [21 ] }
$$

But we are forgetting the hive wherein the swarming bees have begun to lose patience, the hive whose black and vibrating waves are bubbling and overflowing, like a brazen cup beneath an ardent sun. It is noon; and the heat so great that the assembled trees would seem al- 


\section{The Life of the Bee}

most to hold back their leaves, as a man holds his breath before something very tender but very grave. The bees give their honey and sweet-smelling wax to the man who attends them; but more precious gift still is their summoning him to the gladness of June, to the joy of the beautiful months; for events in which bees take part happen only when skies are pure, at the winsome hours of the year when flowers keep holiday. They are the soul of the summer, the clock whose dial records the moments of plenty; they are the untiring wing on which delicate perfumes float; the guide of the quivering light-ray, the song of the slumberous, languid air; and their flight is the token, the sure and melodious note, of all the myriad fragile joys that are born in the heat and dwell in the sunshine. They teach us to tune our ear to the softest, most intimate whisper of these 


\section{The Swarm}

good, natural hours. To him who has known them and loved them, a summer where there are no bees becomes as sad and as empty as one without flowers or birds.

$$
\text { [22] }
$$

The man who never before has beheld the swarm of a populous hive must regard this riotous, bewildering spectacle with some apprehension and diffidence. He will be almost afraid to draw near; he will wonder can these be the earnest, the peace-loving, hard-working bees whose movements he has hitherto followed? It was but a few moments before he had seen them troop in from all parts of the country, as pre-occupied, seemingly, as little housewives might be, with no thoughts beyond household cares. $\mathrm{He}$ had watched them stream into the hive, imperceptibly almost, out of breath, 


\section{The Life of the Bee}

eager, exhausted, full of discreet agitation; and had seen the young amazons stationed at the gate salute them, as they passed by, with the slightest wave of antennæ. And then, the inner court reached, they had hurriedly given their harvest of honey to the adolescent portresses always stationed within, exchanging with these at most the three or four probably indispensable words; or perhaps they would hasten themselves to the vast magazines that encircle the brood-cells, and deposit the two heavy baskets of pollen that depend from their thighs, thereupon at once going forth once more, without giving a thought to what might be passing in the royal palace, the work-rooms, or the dormitory where the nymphs lie asleep; without for one instant joining in the babel of the public place in front of the gate, where it is the wont of the cleaners, at 


\section{The Swarm}

time of great heat, to congregate and to gossip.

$$
\text { [23] }
$$

To-day this is all changed. A certain number of workers, it is true, will peacefully go to the fields, as though nothing were happening; will come back, clean the hive, attend to the brood-cells, and hold altogether aloof from the general ecstasy. These are the ones that will not accompany the queen; they will remain to guard the old home, feed the nine or ten thousand eggs, the eighteen thousand larvæ, the thirty-six thousand nymphs and seven or eight royal princesses, that to-day shall all be abandoned. Why they have been singled out for this austere duty, by what law, or by whom, it is not in our power to divine. To this mission of theirs they remain inflexibly, tranquilly faithful; and though 


\section{The Life of the Bee}

I have many times tried the experiment of sprinkling a colouring matter over one of these resigned Cinderellas, that are moreover easily to be distinguished in the midst of the rejoicing crowds by their serious and somewhat ponderous gait, it is rarely indeed that $I$ have found one of them in the delirious throng of the swarm.

$$
\text { [24] }
$$

And yet, the attraction must seem irresistible. It is the ecstasy of the perhaps unconscious sacrifice the god has ordained; it is the festival of honey, the triumph of the race, the victory of the future : the one day of joy, of forgetfulness and folly; the only Sunday known to the bees. It would appear to be also the solitary day upon which all eat their fill, and revel, to heart's content, in the delights of the treasure themselves have 


\section{The Swarm}

amassed. It is as though they were prisoners to whom freedom at last had been given, who had suddenly been led to a land of refreshment and plenty. They exult, they cannot contain the joy that is in them. They come and go aimlessly, - they whose every movement has always its precise and useful purpose - they depart and return, sally forth once again to see if the queen be ready, to excite their sisters, to beguile the tedium of waiting. They fly much higher than is their wont, and the leaves of the mighty trees round about all quiver responsive. They have left trouble behind, and care. They no longer are meddling and fierce, aggressive, suspicious, untamable, angry. Man - the unknown master whose sway they never acknowledge, who can subdue them only by conforming to their every law, to their habits of labour, and following step by step the 


\section{The Life of the Bee}

path that is traced in their life by an intellect nothing can thwart or turn from its purpose, by a spirit whose aim is always the good of the morrow - on this day man can approach them, can divide the glittering curtain they form as they fly round and round in songful circles; he can take them up in his hand, and gather them as he would a bunch of grapes; for to-day, in their gladness, possessing nothing, but full of faith in the future, they will submit to everything and injure no one, provided only they be not separated from the queen who bears that future within her.

$$
\text { [25] }
$$

But the veritable signal has not yet been given. In the hive there is indescribable confusion; and a disorder whose meaning escapes us. At ordinary times each bee, once returned to her 


\section{The Swarm}

home, would appear to forget her possession of wings; and will pursue her active labours, making scarcely a movement, on that particular spot in the hive that her special duties assign. But to-day they all seem bewitched; they fly in dense circles round and round the polished walls, like a living jelly stirred by an invisible hand. The temperature within rises rapidly, — to such a degree, at times, that the wax of the buildings will soften, and twist out of shape. The queen, who ordinarily never will stir from the centre of the comb, now rushes wildly, in breath. less excitement, over the surface of the vehement crowd that turn and turn on themselves. Is she hastening their departure, or trying to delay it? Does she command, or haply implore? Does this prodigious emotion issue from her, or is she its victim? Such knowledge as we possess of the general psychology of the 


\section{The Life of the Bee}

bee warrants the belief that the swarming always takes place against the old sovereign's will. For indeed the ascetic workers, her daughters, regard the queen above all as the organ of love, indispensable, certainly, and sacred, but in herself somewhat unconscious, and often of feeble mind. They treat her like a mother in her dotage. Their respect for her, their tenderness, is heroic and boundless. The purest honey, specially distilled and almost entirely assimilable, is reserved for her use alone. She has an escort that watches over her by day and by night, that facilitates her maternal duties and gets ready the cells wherein the eggs shall be laid; she has loving attendants who pet and caress her, feed her and clean her, and even absorb her excrement. Should the least accident befall her the news will spread quickly from group to group, and the whole population will rush 


\section{The Swarm}

to and fro in loud lamentation. Seize her, imprison her, take her away from the hive at a time when the bees shall have no hope of filling her place, owing, it may be, to her having left no predestined descendants, or to there being no larvæ less than three days old (for a special nourishment is capable of transforming these into royal nymphs, such being the grand democratic principle of the hive, and a counterpoise to the preroga tives of maternal predestination), and then, her loss once known, after two or three hours, perhaps, for the city is vast, work will cease in almost every direction. The young will no longer be cared for; part of the inhabitants will wander in every direction, seeking their mother, in quest of whom others will sally forth from the hive; the workers engaged in constructing the comb will fall asunder and scatter, the foragers no longer will visit the 6 


\section{The Life of the Bee}

flowers, the guard at the entrance will abandon their post; and foreign marauders, all the parasites of honey, forever on the watch for opportunities of plunder, will freely enter and leave without any one giving a thought to the defence of the treasure that has been so laboriously gathered. And poverty, little by little, will steal into the city; the population will dwindle; and the wretched inhabitants soon will perish of distress and despair, though every flower of summer burst into bloom before them.

But let the queen be restored before her loss has become an accomplished, irremediable fact, before the bees have grown too profoundly demoralised, - for in this they resemble men: a prolonged regret, or misfortune, will impair their intellect and degrade their character, - let her be restored but a few hours later, and they will receive her with extraordinary, 


\section{The Swarm}

pathetic welcome. They will flock eagerly round her; excited groups will climb over each other in their anxiety to draw near; as she passes among them they will caress her with the long antennæ that contain so many organs as yet unexplained; they will present her with honey, and escort her tumultuously back to the royal chamber. And order at once is restored, work resumed, from the central comb of the brood-cells to the furthest annex where the surplus honey is stored; the foragers go forth, in long black files, to return, in less than three minutes sometimes, laden with nectar and pollen; streets are swept, parasites and marauders killed or expelled; and the hive soon resounds with the gentle, monotonous cadence of the strange hymn of rejoicing, which is, it would seem, the hymn of the royal presence. 


\section{The Life of the Bee}

$$
\text { [26] }
$$

There are numberless instances of the absolute attachment and devotion that the workers display towards their queen. Should disaster befall the little republic; should the hive or the comb collapse, should man prove ignorant, or brutal; should they suffer from famine, from cold or disease, and perish by thousands, it will still be almost invariably found that the queen will be safe and alive, beneath the corpses of her faithful daughters. For they will protect her, help her to escape; their bodies will provide both rampart and shelter; for her will be the last drop of honey, the wholesomest food. And be the disaster never so great, the city of virgins will not lose heart so long as the queen be alive. Break their comb twenty times in succession, take twenty times from them their young and their food, 


\section{The Swarm}

you still shall never succeed in making them doubt of the future; and though they be starving, and their number so small that it scarcely suffices to shield their mother from the enemy's gaze, they will set about to reorganize the laws of the colony, and to provide for what is most pressing; they will distribute the work in accordance with the new necessities of this disastrous moment, and thereupon will immediately re-assume their labours with an ardour, a patience, a tenacity and intelligence not often to be found existing to such a degree in nature, true though it be that most of its creatures display more confidence and courage than man.

But the presence of the queen is not even essential for their discouragement to vanish and their love to endure. It is enough that she should have left, at the moment of her death or departure, the very slenderest hope of descendants. "We 85 


\section{The Life of the Bee}

have seen a colony," says Langstroth, one of the fathers of modern apiculture, "that had not bees sufficient to cover a comb of three inches square, and yet endeavoured to rear a queen. For two whole weeks did they cherish this hope; finally, when their number was reduced by one-half, their queen was born, but her wings were imperfect, and she was unable to fly. Impotent as she was, her bees did not treat her with the less respect. A week more, and there remained hardly a dozen bees; yet a few days, and the queen had vanished, leaving a few wretched, inconsolable insects upon the combs."

$$
\text { [27] }
$$

There is another instance, and one that reveals most palpably the ultimate gesture of filial love and devotion. It arises from one of the extraordinary ordeals that our recent and tyrannical intervention inflicts 


\section{The Swarm}

on these hapless, unflinching heroines. I, in common with all amateur bee-keepers, have more than once had impregnated queens sent me from Italy; for the Italian species is more prolific, stronger, more active, and gentler than our own. It is the custom to forward them in small, perforated boxes. In these some food is placed, and the queen enclosed, together with a certain number of workers, selected as far as possible from among the oldest bees in the hive. (The age of the bee can be readily told by its body, which gradually becomes more polished, thinner, and almost bald; and more particularly by the wings, which hard work uses and tears.) It is their mission to feed the queen during the journey, to tend her and guard her. I would frequently find, when the box arrived, that nearly every one of the workers was dead. On one occasion, indeed, they had all perished of hunger; 


\section{The Life of the Bee}

but in this instance as in all others the queen was alive, unharmed, and full of vigour; and the last of her companions had probably passed away in the act of presenting the last drop of honey she held in her sac to the queen, who was symbol of a life more precious, more vast, than her own.

$$
\text { [28] }
$$

This unwavering affection having come under the notice of man, he was able to turn to his own advantage the qualities to which it gives rise, or that it perhaps contains: the admirable political sense, the passion for work, the perseverance, magnanimity, and devotion to the future. It has allowed him, in the course of the last few years, to a certain extent to domesticate these intractable insects, though without their knowledge; for they yield to no foreign strength, and 


\section{The Swarm}

in their unconscious servitude obey only the laws of their own adoption. Man may believe, if he choose, that, possessing the queen, he holds in his hand the destiny and soul of the hive. In accordance with the manner in which he deals with her - as it were, plays with herhe can increase and hasten the swarm or restrict and retard it; he can unite or divide colonies, and direct the emigration of kingdoms. And yet it is none the less true that the queen is essentially merely a sort of living symbol, standing, as all symbols must, for a vaster although less perceptible principle; and this principle the apiarist will do well to take into account, if he would not expose himself to more than one unexpected reverse. For the bees are by no means deluded. The presence of the queen does not blind them to the existence of their veritable sovereign, immaterial and everlasting, which is no 


\section{The Life of the Bee}

other than their fixed idea. Why inquire as to whether this idea be conscious or not? Such speculation can have value only if our anxiety be to determine whether we should more rightly admire the bees that have the idea, or nature that has planted it in them. Wherever it lodge, in the vast unknowable body or in the tiny ones that we see, it merits our deepest attention; nor may it be out of place here to observe that it is the habit we have of subordinating our wonder to accidents of origin or place, that so often causes us to lose the chance of deep admiration; which of all things in the world is the most helpful to us.

$$
\text { [29] }
$$

These conjectures may perhaps be regarded as exceedingly venturesome, and possibly also as unduly human. It may be urged that the bees, in all probability, 


\section{The Swarm}

have no idea of the kind; that their care for the future, love of the race, and many other feelings we choose to ascribe to them, are truly no more than forms assumed by the necessities of life, the fear of suffering or death, and the attraction of pleasure. Let it be so; look on it all as a figure of speech; it is a matter to which I attach no importance. The one thing certain here, as it is the one thing certain in all other cases, is that, under special circumstances, the bees will treat their queen in a special manner. The rest is all mystery, around which we only can weave more or less ingenious and pleasant conjecture. And yet, were we speaking of man in the manner wherein it were wise perhaps to speak of the bee, is there very much more we could say? $\mathrm{He}$ too yields only to necessity, the attraction of pleasure, and the fear of suffering; and what we call our intellect has the same 


\section{The Life of the Bee}

origin and mission as what in animals we choose to term instinct. We do certain things, whose results we conceive to be known to us; other things happen, and we flatter ourselves that we are better equipped than animals can be to divine their cause; but, apart from the fact that this supposition rests on no very solid foundation, events of this nature are rare and infinitesimal, compared with the vast mass of others that elude comprehension; and all, the pettiest and the most sublime, the best known and the most inexplicable, the nearest and the most distant, come to pass in a night so profound that our blindness may well be almost as great as that we suppose in the bee.

$$
\text { [30] }
$$

"All must agree," remarks Buffon, who has a somewhat amusing prejudice against the bee, — "all must agree that 


\section{The Swarm}

these flies, individually considered, possess far less genius than the dog, the monkey, or the majority of animals; that they display far less docility, attachment, or sentiment; that they have, in a word, less qualities that relate to our own; and from that we may conclude that their apparent intelligence derives only from their assembled multitude; nor does this union even argue intelligence, for it is governed by no moral considerations, it being without their consent that they find themselves gathered together. This society, therefore, is no more than a physical assemblage ordained by nature, and independent either of knowledge, or reason, or aim. The mother-bee produces ten thousand individuals at a time, and in the same place; these ten thousand individuals, were they a thousand times stupider than I suppose them to be, would be compelled, for the mere purpose of existence, 


\section{The Life of the Bee}

to contrive some form of arrangement; and, assuming that they had begun by injuring each other, they would, as each one possesses the same strength as its fellow, soon have ended by doing each other the least possible harm, or, in other words, by rendering assistance. They have the appearance of understanding each other, and of working for a common aim; and the observer, therefore, is apt to endow them with reasons and intellect that they truly are far from possessing. He will pretend to account for each action, show a reason behind every movement; and from thence the gradation is easy to proclaiming them marvels, or monsters, of innumerable ideas. Whereas the truth is that these ten thousand individuals, that have been produced simultaneously, that have lived together, and undergone metamorphosis at more or less the same time, cannot fail all to do the 


\section{The Swarm}

same thing, and are compelled, however slight the sentiment within them, to adopt common habits, to live in accord and union, to busy themselves with their dwelling, to return to it after their journeys, etc., etc. And on this foundation arise the architecture, the geometry, the order, the foresight, love of country, -in a word, the republic; all springing, as we have seen, from the admiration of the observer."

There we have our bees explained in a very different fashion. And if it seem more natural at first, is it not for the very simple reason that it really explains almost nothing? I will not allude to the material errors this chapter contains; I will only ask whether the mere fact of the bees accepting a common existence, while doing each other the least possible harm, does not in itself argue a certain intelligence. And does not this intelligence appear the more remarkable to us as we 


\section{The Life of the Bee}

more closely examine the fashion in which these "ten thousand individuals" avoid hurting each other, and end by giving assistance? And further, is this not the history of ourselves; and does not all that the angry old naturalist says apply equally to every one of our human societies? And yet once again: if the bee is indeed to be credited with none of the feelings or ideas that we have ascribed to it, shall we not very willingly shift the ground of our wonder? If we must not admire the bee, we will then admire nature; the moment must always come when admiration can be no longer denied us, nor shall there be loss to us through our having retreated, or waited.

$$
\text { [3I] }
$$

However these things may be, and without abandoning this conjecture of ours, that at least has the advantage of connecting 


\section{The Swarm}

in our mind certain actions that have evident connection in fact, it is certain that the bees have far less adoration for the queen herself than for the infinite future of the race that she represents. They are not sentimental; and should one of their number return from work so severely wounded as to be held incapable of further service, they will ruthlessly expel her from the hive. And yet it cannot be said that they are altogether incapable of a kind of personal attachment towards their mother. They will recognise her from among all. Even when she is old, crippled, and wretched, the sentinels at the door will never allow another queen to enter the hive, though she be young and fruitful. It is true that this is one of the fundamental principles of their polity, and never relaxed except at times of abundant honey, in favour of some foreign worker who shall be well laden with food. 


\section{The Life of the Bee}

When the queen has become completely sterile, the bees will rear a certain number of royal princesses to fill her place. But what becomes of the old sovereign? As to this we have no precise knowledge; but it has happened, at times, that apiarists have found a magnificent queen, in the flower of her age, on the central comb of the hive; and in some obscure corner, right at the back, the gaunt, decrepit "old mistress," as they call her in Normandy. In such cases it would seem that the bees have to exercise the greatest care to protect her from the hatred of the vigorous rival who longs for her death; for queen hates queen so fiercely that two who might happen to be under the same roof would immediately fly at each other. It would be pleasant to believe that the bees are thus providing their ancient sovereign with a humble shelter in a remote corner of the city, where she may end her days in peace. 


\section{The Swarm}

Here again we touch one of the thousand enigmas of the waxen city; and it is once more proved to us that the habits and the policy of the bees are by no means narrow, or rigidly predetermined; and that their actions have motives far more complex than we are inclined to suppose.

$$
\text { [ } 32 \text { ] }
$$

But we are constantly tampering with what they must regard as immovable laws of nature; constantly placing the bees in a position that may be compared to that in which we should ourselves be placed were the laws of space and gravity, of light and heat, to be suddenly suppressed around us. What are the bees to do when we, by force or by fraud, introduce a second queen into the city? It is probable that, in a state of nature, thanks to the sentinels at the gate, such an event has never occurred since they first came 


\section{The Life of the Bee}

into the world. But this prodigious conjuncture does not scatter their wits; they still contrive to reconcile the two principles that they appear to regard in the light of divine commands. The first is that of unique maternity, never infringed except in the case of sterility in the reigning queen, and even then only very exceptionally; the second is more curious still, and, although never transgressed, susceptible of what may almost be termed a Judaic evasion. It is the law that invests the person of a queen, whoever she be, with a sort of inviolability. It would be a simple matter for the bees to pierce the intruder with their myriad envenomed stings; she would die on the spot, and they would merely have to remove the corpse from the hive. But though this sting is always held ready to strike, though they make constant use of it in their fights among themselves, they will never draw it against 


\section{The Swarm}

a queen; nor will a queen ever draw hers on a man, an animal, or an ordinary bee. She will never unsheath her royal weapon - curved, in scimeter fashion, instead of being straight, like that of the ordinary bee - save only in the case of her doing battle with an equal: in other words, with a sister queen.

No bee, it would seem, dare take on herself the horror of direct and bloody regicide. Whenever, therefore, the good order and prosperity of the republic appear to demand that a queen shall die, they endeavour to give to her death some semblance of natural decease, and by infinite subdivision of the crime, to render it almost anonymous.

They will, therefore, to use the picturesque expression of the apiarist, "ball" the queenly intruder; in other words, they will entirely surround her with their innumerable interlaced bodies. They will ror 


\section{The Life of the Bee}

thus form a sort of living prison wherein the captive is unable to move; and in this prison they will keep her for twentyfour hours, if need be, till the victim die of suffocation or hunger.

But if, at this moment, the legitimate queen draw near, and, scenting a rival, appear disposed to attack her, the living walls of the prison will at once fly open; and the bees, forming a circle around the two enemies, will eagerly watch the strange duel that will ensue, though remaining strictly impartial, and taking no share in it. For it is written that against a mother the sting may be drawn by a mother alone; only she who bears in her flanks close on two million lives appears to possess the right with one blow to inflict close on two million deaths.

But if the combat last too long, without any result, if the circular weapons glide harmlessly over the heavy cuirasses, if one 


\section{The Swarm}

of the queens appear anxious to make her escape, then, be she the legitimate sovereign or be she the stranger, she will at once be seized and lodged in the living prison until such time as she manifest once more the desire to attack her foe. It is right to add, however, that the numerous experiments that have been made on this subject have almost invariably resulted in the victory of the reigning queen, owing perhaps to the extra courage and ardour she derives from the knowledge that she is at home, with her subjects around her, or to the fact that the bees, however impartial while the fight is in progress, may possibly display some favouritism in their manner of imprisoning the rivals; for their mother would seem scarcely to suffer from the confinement, whereas the stranger almost always emerges in an appreciably bruised and enfeebled condition. 


\section{The Life of the Bee}

\section{[33 ]}

There is one simple experiment which proves the readiness with which the bees will recognise their queen, and the depth of the attachment they bear her. Remove her from the hive, and there will soon be manifest all the phenomena of anguish and distress that $I$ have described in a preceding chapter. Replace her, a few hours later, and all her daughters will hasten towards her, offering honey. One section will form a lane, for her to pass through ; others, with head bent low and abdomen high in the air, will describe before her great semicircles throbbing with sound; hymning, doubtless, the chant of welcome their rites dictate for moments of supreme happiness or solemn respect.

But let it not be imagined that a foreign queen may with impunity be substituted for the legitimate mother. The bees will 


\section{The Swarm}

at once detect the imposture; the intruder will be seized, and immediately enclosed in the terrible, tumultuous prison, whose obstinate walls will be relieved, as it were, till she dies; for in this particular instance it hardly ever occurs that the stranger emerges alive.

And here it is curious to note to what diplomacy and elaborate stratagem man is compelled to resort in order to delude these little sagacious insects, and bend them to his will. In their unswerving loyalty, they will accept the most unexpected events with touching courage, regarding them probably as some new and inevitable fatal caprice of nature. And, indeed, all this diplomacy notwithstanding, in the desperate confusion that may follow one of these hazardous expedients, it is on the admirable good sense of the bee that man always, and almost empirically, relies ; on the inex- 


\section{The Life of the Bee}

haustible treasure of their marvellous laws and customs, on their love of peace and order, their devotion to the public weal, and fidelity to the future; on the adroit strength, the earnest disinterestedness, of their character, and, above all, on the untiring devotion with which they fulfil their duty. But the enumeration of such procedures belongs rather to technical treatises on apiculture, and would take us too far. ${ }^{1}$

1 The stranger queen is usually brought into the hive enclosed in a little cage, with iron wires, which is hung between two combs. The cage has a door made of wax and honey, which the workers, their anger over, proceed to gnaw, thus freeing the prisoner, whom they will often receive without any ill-will. Mr. Simmins, manager of the great apiary at Rottingdean, has recently discovered another method of introducing a queen, which, being extremely simple and almost invariably successful, bids fair to be generally adopted by apiarists who value their art. It is the behaviour of the queen that usually makes her introduction a matter of so great difficulty. She is almost 


\section{The Swarm}

\section{[34 ]}

As regards this personal affection of which we have spoken, there is one word more to be said. That such affection

distracted, flies to and fro, hides, and generally comports herself as an intruder, thus arousing the suspicions of the bees, which are soon confirmed by the workers' examination. Mr. Simmins at first completely isolates the queen he intends to introduce, and lets her fast for half an hour. He then lifts a corner of the inner cover of the orphaned hive, and places the strange queen on the top of one of the combs. Her former isolation having terrified her, she is delighted to find herself in the midst of the bees; and being famished she eagerly accepts the food they offer her. The workers, deceived by her assurance, do not examine her, but probably imagine that their old queen has returned, and welcome her joyfully. It would seem, therefore, that, contrary to the opinion of Huber and all other investigators, the bees are not capable of recognising their queen. In any event, the two explanations, which are both equally plausible - though the truth may lurk, perhaps, in a third, that is not yet known to us only prove once again how complex and obscure is the psychology of the bee. And from this, as from all 


\section{The Life of the Bee}

exists is certain, but it is certain also that its memory is exceedingly short-lived. Dare to replace in her kingdom a mother whose exile has lasted some days, and her indignant daughters will receive her in such a fashion as to compel you hastily to snatch her from the deadly imprisonment reserved for unknown queens. For the bees have had time to transform a dozen workers' habitations into royal cells, and the future of the race is no longer in danger. Their affection will increase, or dwindle $_{j}$ in the degree that the queen represents the future. Thus we often find, when a virgin queen is performing the perilous ceremony known as the "nuptial flight," of which I will speak later, that her subjects are so fearful of losing her that they will all accompany her on this

questions that deal with life, we can draw one conclusion only: that, till better obtain, curiosity still must rule in our heart. 


\section{The Swarm}

tragic and distant quest of love. This they will never do, however, if they be provided with a fragment of comb containing brood-cells, whence they shall be able to rear other queens. Indeed, their affection even may turn into fury and hatred should their sovereign fail in her duty to that sort of abstract divinity that we should call future society, which the bees would appear to regard far more seriously than we. It happens, for instance, at times, that apiarists for various reasons will prevent the queen from joining a swarm by inserting a trellis into the hive; the nimble and slender workers will flit through it, unperceiving, but to the poor slave of love, heavier and more corpulent than her daughters, it offers an impassable barrier. The bees, when they find that the queen has not followed, will return to the hive, and scold the unfortunate prisoner, hustle and ill-treat her, 


\section{The Life of the Bee}

accusing her of laziness, probably, or suspecting her of feeble mind. On their second departure, when they find that she still has not followed, her ill-faith becomes evident to them, and their attacks grow more serious. And finally, when they shall have gone forth once more, and still with the same result, they will almost always condemn her, as being irremediably faithless to her destiny and to the future of the race, and put her to death in the royal prison.

\section{[35 ]}

It is to the future, therefore, that the bees subordinate all things; and with a foresight, a harmonious co-operation, a skill in interpreting events and turning them to the best advantage, that must compel our heartiest admiration, particularly when we remember in how startling and supernatural a light our recent inter- 


\section{The Swarm}

rention must present itself to them. It may be said, perhaps, that in the last instance we have given, they place a very false construction upon the queen's inability to follow them. But would our powers of discernment be so very much subtler, if an intelligence of an order entirely different from our own, and served by a body so colossal that its movements were almost as imperceptible as those of a natural phenomenon, were to divert itself by laying traps of this kind for us? Has it not taken us thousands of years to invent a sufficiently plausible explanation for the thunderbolt? There is a certain feebleness that overwhelms every intellect the moment it emerges from its own sphere, and is brought face to face with events not of its own initiation. And, besides, it is quite possible that if this ordeal of the trellis were to obtain more regularly and 


\section{The Life of the Bee}

generally among the bees, they would end by detecting the pitfall, and by taking steps to elude it. They have mastered the intricacies of the movable comb, of the sections that compel them to store their surplus honey in little boxes symmetrically piled; and in the case of the still more extraordinary innovation of foundation wax, where the cells are indicated only by a slender circumference of wax, they are able at once to grasp the advantages this new system presents; they most carefully extend the wax, and thus, without loss of time or labour, construct perfect cells. So long as the event that confronts them appear not a snare devised by some cunning and malicious god, the bees may be trusted always to discover the best, nay, the only human, solution. Let me cite an instance; an event, that, though occurring in nature, is still in itself wholly abnor- 


\section{The Swarm}

mal. I refer to the manner in which the bees will dispose of a mouse or a slug that may happen to have found its way into the hive. The intruder killed, they have to deal with the body, which will very soon poison their dwelling. If it be impossible for them to expel or dismember it, they will proceed methodically and hermetically to enclose it in a veritable sepulchre of propolis and wax, which will tower fantastically above the ordinary monuments of the city. In one of my hives last year I discovered three such tombs side by side, erected with party-walls, like the cells of the comb, so that no wax should be wasted. These tombs the prudent. grave-diggers had raised over the remains of three snails that a child had introduced into the hive. As a rule, when dealing with snails, they will be content to seal up with wax the orifice of the shell. But in this case. 


\section{The Life of the Bee}

the shells were more or less cracked and broken; and they had considered it simpler, therefore, to bury the entire snail; and had further contrived, in order that circulation in the entrance-hall might not be impeded, a number of galleries exactly proportionate, not to their own girth, but to that of the males, which are almost twice as large as themselves. Does not this instance, and the one that follows, warrant our believing that they would in time discover the cause of the queen's inability to follow them through the trellis? They have a very nice sense of proportion, and of the space required for the movement of bodies. In the regions where the hideous death's-head sphinx, the acherontia atropos, abounds, they construct little pillars of. wax at the entrance of the hive, so restricting the dimension as to prevent the passage of the nocturnal marauder's enormous abdomen. 


\section{The Swarm}

\section{[36]}

But enough on this point; were $I$ to cite every instance I should never have done. To return to the queen, whose position in the hive, and the part that she plays therein, we shall most fitly describe by declaring her to be the captive heart of the city, and the centre around which its intelligence revolves. Unique sovereign though she be, she is also the royal servant, the responsible delegate of love, and its captive custodian. Her people serve her and venerate her; but they never forget that it is not to her person that their homage is given, but to the mission that she fulfils, and the destiny she represents. It would not be easy for us to find a human republic whose scheme comprised more of the desires of our planet ; or a democracy that offered an independence more 


\section{The Life of the Bee}

perfect and rational, combined with a submission more logical and more complete. And nowhere, surely, should we discover more painful and absolute sacrifice. Let it not be imagined that I admire this sacrifice to the extent that I admire its results. It were evidently to be desired that these results might be obtained at the cost of less renouncement and suffering. But; the principle once accepted, - and this is needful, perhaps, in the scheme of our globe, - its organisation compels our wonder. Whatever the human truth on this point may be, life, in the hive, is not looked on as a series of more or less pleasant hours, whereof it is wise that those moments only should be soured and embittered that are essential for maintaining existence. The bees regard it as a great common duty, impartially distributed amongst them all, and tending towards 


\section{The Swarm}

a future that goes further and further back ever since the world began. And, for the sake of this future, each one renounces more than half of her rights and her joys. The queen bids farewell to freedom, the light of day, and the calyx of flowers; the workers give five or six years of their life, and shall never know love, or the joys of maternity. The queen's brain turns to pulp, that the reproductive organs may profit; in the workers these organs atrophy, to the benefit of their intelligence. Nor would it be fair to allege that the will plays no part in all these renouncements. We have seen that each worker's larva can be transformed into a queen if lodged and fed on the royal plan; and similarly could each royal larva be turned into worker if her food were changed and her cell reduced. These mysterious elections take place every day in the golden 


\section{The Life of the Bee}

shade of the hive. It is not chance that controls them, but a wisdom whose deep loyalty, gravity, and unsleeping watchfulness man alone can betray: a wisdom that makes and unmakes, and keeps careful watch over all that happens within and without the city. If sudden flowers abound, or the queen grow old, or less fruitful; if population increase, and be pressed for room, you then shall find that the bees will proceed to rear royal cells. But these cells may be destroyed if the harvest fail, or the hive be enlarged. Often they will be retained so long as the young queen have not accomplished, or succeeded in, her marriage flight, - to be at once annihilated when she returns, trailing behind her, trophywise, the infallible sign of her impregnation. Who shall say where the wisdom resides that can thus balance present and future, and prefer what is not yet visible 


\section{The Swarm}

to that which already is seen? Where the anonymous prudence that selects and abandons, raises and lowers; that of so many workers makes so many queens, and of so many mothers can make a people of virgins? We have said elsewhere that it lodged in the "Spirit of the Hive," but where shall this spirit of the hive be looked for if not in the assembly of workers? To be convinced of its residence there, we need not perhaps have studied so closely the habits of this royal republic. It was enough to place under the microscope, as Dujardin, Brandt, Girard, Vogel, and other entomologists have done, the little uncouth and careworn head of the virgin worker side by side with the somewhat empty skull of the queen and the male's magnificent cranium, glistening with its twenty-six thousand eyes. Within this tiny head we should find the workings 


\section{The Life of the Bee}

of the vastest and most magnificent brain of the hive: the most beautiful and complex, the most perfect, that, in another order and with a different organisation, is to be found in nature after that of man. Here again, as in every quarter where the scheme of the world is known to us, there where the brain is, are authority and victory, veritable strength and wisdom. And here again it is an almost invisible atom of this mysterious substance that organises and subjugates matter, and is able to create its own little triumphant and permanent place in the midst of the stupendous, inert forces of nothingness and death. ${ }^{1}$

1 The brain of the bee, according to the calculation of Dujardin, constitutes the $1-174^{\text {th }}$ part of the insect's weight, and that of the ant the I-296th. On the other hand the peduncular parts, whose development usually keeps pace with the triumphs the intellect achieves over instinct, are somewhat less important in the bee than in the ant, It would seem 


\section{The Swarm}

\section{[37 ]}

And now to return to our swarming hive, where the bees have already given the signal for departure, without waiting for these reflections of ours to come to an end. At the moment this signal is given, it is as though one sudden mad impulse had simultaneously flung open wide every single gate in the city; and the black throng issues, or rather pours forth in a double, or treble, or quadruple jet, as the number of exits may be ; in a tense, direct, vibrating, uninterrupted stream that at once dissolves and melts into space, where the myriad transparent, furious wings weave a tissue throbbing with sound. And this for some moments will

to result from these estimates - which are of course hypothetical, and deal with a matter that is exceedingly obscure - that the intellectual value of the bee and the ant must be more or less equal. 


\section{The Life of the Bee}

quiver right over the hive, with prodigious rustle of gossamer silks that countless electrified hands might be ceaselessly rending and stitching; it floats undulating, it trembles and flutters like a veil of gladness invisible fingers support in the sky, and wave to and fro, from the flowers to the blue, expecting sublime advent or departure. And at last one angle declines another is lifted; the radiant mantle unites its four sunlit corners; and like the wonderful carpet the fairy-tale speaks of, that flits across space to obey its master's command, it steers its straight course, bending forward a little as though to hide in its folds the sacred presence of the future, towards the willow, the pear-tree, or lime whereon the queen has alighted; and round her each rhythmical wave comes to rest, as though on a nail of gold, and suspends its fabric of pearls and of luminous wings. 


\section{The Swarm}

And then there is silence once more; and, in an instant, this mighty tumult, this awful curtain apparently laden with unspeakable menace and anger, this bewildering golden hail that streamed upon every object near - all these become merely a great, inoffensive, peaceful cluster of bees, composed of thousands of little motionless groups, that patiently wait, as they hang from the branch of a tree, for the scouts to return who have gone in search of a place of shelter.

\section{[ $3^{8}$ ]}

This is the first stage of what is known as the "primary swarm" at whose head the old queen is always to be found. They will settle as a rule on the shrub or the tree that is nearest the hive; for the queen, besides being weighed down by her eggs, has dwelt in constant darkness ever since her marriage-flight, or the 


\section{The Life of the Bee}

swarm of the previous year; and is naturally reluctant to venture far into space, having indeed almost forgotten the use of her wings.

The bee-keeper waits till the mass be completely gathered together; then, having covered his head with a large straw hat (for the most inoffensive bee will conceive itself caught in a trap if entangled in hair, and will infallibly use its sting), but, if he be experienced, wearing neither mask nor veil; having taken the precaution only of plunging his arms in cold water up to the elbow, he proceeds to gather the swarm by vigorously shaking the bough from which the bees depend over an inverted hive. Into this hive the cluster will fall as heavily as an over-ripe fruit. Or, if the branch be too stout, he can plunge a spoon into the mass; and deposit where he will the living spoonfuls, as though he were ladling out corn. He 


\section{The Swarm}

need have no fear of the bees that are buzzing around him, settling on his face and hands. The air resounds with their song of ecstasy, which is different far from their chant of anger. He need have no fear that the swarm will divide, or grow fierce, will scatter, or try to escape. This is a day, I repeat, when a spirit of holiday would seem to animate these mysterious workers, a spirit of confidence, that apparently nothing can trouble. They have detached themselves from the wealth they had to defend, and they no longer recognise their enemies. They become inoffensive because of their happiness, though why they are happy we know not, except it be because they are obeying their law. A moment of such blind happiness is accorded by nature at times to every living thing, when she seeks to accomplish her end. Nor need we feel any surprise that here the bees are 


\section{The Life of the Bee}

her dupes; we ourselves, who have studied. her movements these centuries past, and with a brain more perfect than that of the bee, we too are her dupes, and know not even yet whether she be benevolent or indifferent, or only basely cruel.

There where the queen has alighted the swarm will remain; and had she descended alone into the hive, the bees would have followed, in long black files, as soon as intelligence had reached them of the maternal retreat. The majority will hasten to her, with utmost eagerness; but large numbers will pause for an instant on the threshold of the unknown abode, and there will describe the circles of solemn rejoicing with which it is their habit to celebrate happy events. "They are beating to arms," say the French peasants. And then the strange home will at once be accepted, and its remotest corners explored; its position in the apiary, its 


\section{The Swarm}

form, its colour, are grasped and retained in these thousands of prudent and faithful little memories. Careful note is taken of the neighbouring landmarks, the new city is founded, and its place established in the mind and the heart of all its inhabitants; the walls resound with the love-hymn of the royal presence, and work begins.

$$
\text { [39] }
$$

But if the swarm be not gathered by man, its history will not end here. It will remain suspended on the branch until the return of the workers, who, acting as scouts, winged quartermasters, as it were, have at the very first moment of swarming sallied forth in all directions in search of a lodging. They return one by one, and render account of their mission; and as it is manifestly impossible for us to fathom the thought of the bees, we can only interpret in human fashion the spec- 


\section{The Life of the Bee}

tacle that they present. We may regard it as probable, therefore, that most careful attention is given to the reports of the various scouts. One of them it may be, dwells on the advantage of some hollow tree it has seen; another is in favour of a crevice in a ruinous wall, of a cavity in a grotto, or an abandoned burrow. The assembly often will pause and deliberate until the following morning. Then at last the choice is made, and approved by all. At a given moment the entire mass stirs, disunites, sets in motion, and then, in one sustained and impetuous flight, that this time knows no obstacle, it will steer its straight course, over hedges and cornfields, over haystack and lake, over river and village, to its determined and always distant goal. It is rarely indeed that this second stage can be followed by man. The swarm returns to nature; and we lose the track of its destiny. 


\section{III}

\section{THE FOUNDATION OF THE CITY}





\section{III}

\section{THE FOUNDATION OF THE} CITY

$$
\text { [40] }
$$

ET us rather consider the proceedings of the swarm the apiarist shall have gathered into his hive. And first of all let us not be forgetful of the sacrifice these fifty thousand virgins have made, who, as Ronsard sings, -

"In a little body bear so true a heart, _,"

and let us, yet once again, admire the courage with which they begin life anew in the desert whereon they have fallen. They have forgotten the splendour and wealth of their native city, where existence had been so admirably organised and 


\section{The Life of the Bee}

certain, where the essence of every flower reminiscent of sunshine had enabled them to smile at the menace of winter. There, asleep in the depths of their cradles, they have left thousands and thousands of daughters, whom they never again will see. They have abandoned, not only the enormous treasure of pollen and propolis they had gathered together, but also more than 120 pounds of honey; a quantity representing more than twelve times the entire weight of the population, and close on 600,000 times that of the individual bee. To man this would mean 42,000 tons of provisions, a vast fleet of mighty ships laden with nourishment more precious than any known to us; for to the bee honey is a kind of liquid life, a species of chyle that is at once assimilated, with almost no waste whatever.

Here, in the new abode, there is nothing; not a drop of honey, not a morsel of T32 


\section{The Foundation of the City}

wax; neither guiding-mark nor point of support. There is only the dreary emptiness of an enormous monument that has nothing but sides and roof. Within the smooth and rounded walls there only is darkness; and the enormous arch above rears itself over nothingness. But useless regrets are unknown to the bee; or in any event it does not allow them to hinder its action. Far from being cast down by an ordeal before which every other courage would succumb, it displays greater ardour than ever. Scarcely has the hive been set in its place, or the disorder allayed that ensued on the bees' tumultuous fall, when we behold the clearest, most unexpected division in that entangled mass. The greater portion, forming in solid columns, like an army obeying a definite order; will proceed to climb the vertical walls of the hive. The cupola reached, the first to arrive will cling with the claws of their 


\section{The Life of the Bee}

anterior legs, those that follow hang on to the first, and so in succession, until long chains have been formed that serve as a bridge to the crowd that rises and rises. And, by slow degrees; these chains, as their number increases, supporting each other and incessantly interweaving, become garlands which, in their turn, the uninterrupted and constant ascension transforms into a thick, triangular curtain, or rather a kind of compact and inverted cone, whose apex attains the summit of the cupola, while its widening base descends to a half, or two-thirds, of the entire height of the hive. And then, the last bee that an inward voice has impelled to form part of this group having added itself to the curtain suspended in darkness, the ascension ceases; all movement slowly dies away in the dome; and, for long hours, this strange inverted cone will wait, in a silence that almost seems awful, in a 


\section{The Foundation of the City}

stillness one might regard as religious, for the mystery of wax to appear.

In the meantime the rest of the bees those, that is, that remained down below in the hive - have shown not the slightest desire to join the others aloft, and pay no heed to the formation of the marvellous curtain on whose folds a magical gift is soon to descend. They are satisfied to examine the edifice and undertake the necessary labours. They carefully sweep the floor, and remove, one by one, twigs, grains of sand, and dead leaves; for the bees are almost fanatically cleanly, and when, in the depths of winter, severe frosts retard too long what apiarists term their "flight of cleanliness," rather than sully the hive they will perish by thousands of a terrible bowel-disease. The males alone are incurably careless, and will impudently bestrew the surface of the comb with their droppings; which the workers 


\section{The Life of the Bee}

are obliged to sweep as they hasten behind them.

The cleaning over, the bees of the profane group that form no part of the cone suspended in a sort of ecstasy, set to work minutely to survey the lower circumference of the common dwelling. Every crevice is passed in review, and filled, covered over with propolis; and the varnishing of the walls is begun, from top to bottom. Guards are appointed to take their stand at the gate; and very soon a certain number of workers will go to the fields and return with their burden of pollen.

$$
\text { [4I] }
$$

Before raising the folds of the mysterious curtain beneath whose shelter are laid the veritable foundations of the home, let us endeavour to form some conception of the sureness of vision, the accurate calculation and industry our little people 


\section{The Foundation of the City}

of emigrants will be called to display in order to adapt this new dwelling to their requirements. 'In the void round about them they must lay the plans for their city, and logically mark out the site of the edifices that must be erected as economically and quickly as possible, for the queen, eager to lay, already is scattering her eggs on the ground. And in this labyrinth of complicated buildings, so far existing only in imagination, laws of ventilation must be considered, of stability, solidity; resistance of the wax must not be lost sight of, or the nature of the food to be stored, or the habits of the queen; ready access must be contrived to all parts, and careful attention be given to the distribution of stores and houses, passages and streets, - this however is in some measure pre-established, the plan already arrived at being organically the best, - and there are countless 


\section{The Life of the Bee}

problems besides, whose enumeration would take too long.

Now, the form of the hive that man offers to the bee knows infinite variety, from the hollow tree or earthenware vessel still obtaining in Asia and Africa, and the familiar bell-shaped constructions of straw which we find in our farmers' kitchengardens or beneath their windows, lost beneath masses of sunflowers, phlox, and hollyhock, to what may really be termed the factory of the model apiarist of today. An edifice, this, that can contain more than three hundred pounds of honey, in three or four stories of superposed combs enclosed in a frame which permits of their being removed and handled, of the harvest being extracted through centrifugal force by means of a turbine, and of their being then restored to their place like a book in a well-ordered library. 


\section{The Foundation of the City}

And one fine day the industry or caprice of man will install a docile swarm in one of these disconcerting abodes. And there the little insect is expected to learn its bearings, to find its way, to establish its home; to modify the seemingly unchangeable plans dictated by the nature of things. In this unfamiliar place it is required to determine the site of the winter storehouses, that must not extend beyond the zone of heat that issues from the half-numbed inhabitants; it must divine the exact point where the broodcells shall concentrate, under penalty of disaster should these be too high or too low, too near to or far from the door. The swarm, it may be, has just left the trunk of a fallen tree, containing one long, narrow, depressed, horizontal gallery; and it finds itself now in a tower-shaped edifice, whose roof is lost in gloom. Or, to take a case that 


\section{The Life of the Bee}

is more usual, perhaps, and one that will give some idea of the surprise habitually in store for the bees: after having lived for centuries past beneath the straw dome of our village hives, they are suddenly transplanted to a species of mighty cupboard, or chest, three or four times as large as the place of their birth ; and installed in the midst of a confused scaffolding of superposed frames, some running parallel to the entrance and some perpendicular; the whole forming a bewildering network that obscures the surfaces of their dwelling.

$$
\text { [ } 4^{2} \text { ] }
$$

And yet, for all this, there exists not a single instance of a swarm refusing its duty, or allowing itself to be baffled or discouraged by the strangeness of its surroundings, except only in the case of the new dwelling being absolutely uninhabi- 


\section{The Foundation of the City}

table, or impregnated with evil odours. And even then the bees will not be disheartened or bewildered; even then they will not abandon their mission. The swarm will simply forsake the inhospitable abode, to seek better fortune some little distance away. And similarly it can never be said of them that they can be induced to undertake any illogical or foolish task. Their common-sense has never been known to fail them; they have never, at a loss for definite decision, erected at haphazard structures of a wild or heterogeneous nature. Though you place the swarm in a sphere, a cube, or a pyramid, in an oval or polygonal basket, you will find, on visiting the bees a few days later, that if this strange assembly of little independent intellects has accepted the new abode, they will at once, and unhesitatingly and unanimously have known how to select the most favourable, often humanly speak- 


\section{The Life of the Bee}

ing the only possible spot in this absurd habitation, in pursuance of a method whose principles may appear inflexible, but whose results are strikingly vivid.

When. installed in one of the huge factories, bristling with frames, that we mentioned just now, these frames will interest them only to the extent in which they provide them with a basis or point of departure for their combs; and they very naturally pay not the slightest heed to the desires or intentions of man. But if the apiarist have taken the precaution of surrounding the upper lath of some of these frames with a narrow fillet of wax, they will be quick to perceive the advantage this tempting offer presents, and will carefully extract the fillet, using their own wax as solder, and will prolong the comb in accordance with the indicated plan. Similarly - and the case is frequent in modern apiculture - if all the frames of 


\section{The Foundation of the City}

the hive into which the bees have been gathered be covered from top to bottom with leaves of foundation-wax, they will not waste time in erecting buildings across or beside these, or in producing useless wax, but, finding that the work is already half finished, they will be satisfied to deepen and lengthen each of the cells designed in the leaf, carefully rectifying these where there is the slightest deviation from the strictest vertical. Proceeding in this fashion, therefore, they will possess in a week a city as luxurious and well-constructed as the one they have quitted; whereas, had they been thrown on their own resources, it would have taken them two or three months to construct so great a profusion of dwellings and storehouses of shining wax. 


\section{The Life of the Bee}

$$
\text { [43] }
$$

This power of appropriation may well be considered to overstep the limit of instinct; and indeed there can be nothing more arbitrary than the distinction we draw between instinct and intelligence properly so-called. Sir John Lubbock, whose observations on ants, bees, and wasps are so interesting and so personal, is reluctant to credit the bee, from the moment it forsakes the routine of its habitual labour, with any power of discernment or reasoning. This attitude of his may be due in some measure to an unconscious bias in favour of the ants, whose ways he has more specially noted; for the entomologist is always inclined to regard that insect as the more intelligent to which he has more particularly devoted himself, and we have to be on our guard against this little personal predilection. As a 


\section{The Foundation of the City}

proof of his theory, Sir John cites as an instance an experiment within the reach of all. If you place in a bottle half a dozen bees and the same number of flies, and lay the bottle down horizontally, with its base to the window, you will find that the bees will persist, till they die of exhaustion or hunger, in their endeavour to discover an issue through the glass; while the flies, in less than two minutes, will all have sallied forth through the neck on the opposite side. From this Sir John Lubbock concludes that the intelligence of the bee is exceedingly limited, and that the fly shows far greater skill in extricating itself from a difficulty, and finding its way. This conclusion, however, would not seem altogether flawless. Turn the transparent sphere twenty times, if you will, holding now the base, now the neck, to the window, and you will find that the bees will turn twenty times with it, so as 


\section{The Life of the Bee}

always to face the light. It is their love of the light, it is their very intelligence, that is their undoing in this experiment of the English savant. They evidently imagine that the issue from every prison must be there where the light shines clearest; and they act in accordance, and persist in too logical action. To them glass is a supernatural mystery they never have met with in nature; they have had no experience of this suddenly impenetrable atmosphere; and, the greater their intelligence, the more inadmissible, more incomprehensible, will the strange obstacle appear. Whereas the featherbrained flies, careless of logic as of the enigma of crystal, disregarding the call of the light, flutter wildly hither and thither, and, meeting here the good fortune that often waits on the simple, who find salvation there where the wiser will perish, necessarily end by discovering 146 


\section{The Foundation of the City}

the friendly opening that restores their liberty to them.

The same naturalist cites yet another proof of the bees' lack of intelligence, and discovers it in the following quotation from the great American apiarist, the venerable and paternal Langstroth :-

"As the fly was not intended to banquet on blossoms, but on substances in which it might easily be drowned, it cautiously alights on the edge of any vessel containing liquid food, and warily helps itself; while the poor bee, plunging in headlong, speedily perishes. The sad fate of their unfortunate companions does not in the least deter others who approach the tempting lure from madly alighting on the bodies of the dying and the dead, to share the same miserable end. No one can understand the extent of their infatuation until he has seen a confectioner's shop assailed by myriads of hungry bees. 


\section{The Life of the Bee}

I have seen thousands strained out from the syrups in which they had perished; thousands more alighting even on the boiling sweets; the floors covered and windows darkened with bees, some crawling, others flying, and others still so completely besmeared as to be able neither to crawl nor to fly - not one in ten able to carry home its ill-gotten spoils, and yet the air filled with new hosts of thoughtless comers."

This, however, seems to me no more conclusive than might be the spectacle of a battlefield, or of the ravages of alcoholism, to a superhuman observer bent on establishing the limits of human understanding. Indeed, less so, perhaps ; for the situation of the bee, when compared with our own, is strange in this world. It was intended to live in the midst of an indifferent and unconscious nature, and not by the side of an extraordinary being 


\section{The Foundation of the City}

who is forever disturbing the most constant laws, and producing grandiose, inexplicable phenomena. In the natural order of things, in the monotonous life of the forest, the madness Langstroth describes would be possible only were some accident suddenly to destroy a hive full of honey. But in this case, even, there would be no fatal glass, no boiling sugar or cloying syrup; no death or danger, therefore, other than that to which every animal is exposed while seeking its prey.

Should we be more successful than they in preserving our presence of mind if some strange power were at every step to ensnare our reason? Let us not be too hasty in condemning the bees for the folly whereof we are the authors, or in deriding their intellect, which is as poorly equipped to foil our artifices as our own would be to foil those of some superior creature unknown to us to-day, but on 


\section{The Life of the Bee}

that account not impossible. None such being known at present, we conclude that we stand on the topmost pinnacle of life on this earth; but this belief, after all, is by no means infallible. I am not assuming that when our actions are unreasonable, or contemptible, we merely fall into the snares that such a creature has laid; though it is not inconceivable that this should one day be proved true. On the other hand, it cannot be wise to deny intelligence to the bee because it has not yet succeeded in distinguishing us from the great ape or the bear. It is certain that there are, in us and about us, influences and powers no less dissimilar whose distinction escapes us as readily.

And finally, to end this apology, wherein I seem somewhat to have fallen into the error I laid to Sir John Lubbock's charge, does not the capacity for folly so 


\section{The Foundation of the City}

great in itself argue intelligence? For thus it is ever in the uncertain domain of the intellect, apparently the most vacillating and precarious condition of matter. The same light that falls on the intellect falls also on passion, whereof none can tell whether it be the smoke of the flame or the wick. In the case above it has not been mere animal desire to gorge themselves with honey that has urged on the bees. They could do this at their leisure in the store-rooms at home. Watch them in an analogous circumstance; follow them; you will see that, as soon as their sac is filled, they will return to the hive and add their spoil to the general store; and visit the marvellous vintage, and leave it, perhaps thirty times in an hour. Their admirable labours, therefore, are inspired by a single desire : zeal to bring as much wealth as they can to the home of their sisters, which is also the home of the 


\section{The Life of the Bee}

future. When we discover a cause as disinterested for the follies of men, we are apt to call them by another name.

$$
\text { [44] }
$$

However, the whole truth must be told. In the midst of the marvels of their industry, their policy, their sacrifice, one thing exists that must always check and weaken our admiration; and this is the indifference with which they regard the misfortunes or death of their comrades. There is a strange duality in the character of the bee. In the heart of the hive all help and love each other. They are as united as the good thoughts that dwell in the same soul. Wound one of them, and a thousand will sacrifice themselves to avenge its injury. But outside the hive they no longer recognise each other. Mutilate them, crush them, - or rather, do nothing of the kind; it would be a 


\section{The Foundation of the City}

useless cruelty, for the fact is established beyond any doubt, - but were you to mutilate, or crush, on a piece of comb placed a few steps from their dwelling, twenty or thirty bees that have all issued from the same hive, those you have left untouched will not even turn their heads. With their tongue, fantastic as a Chinese weapon, they will tranquilly continue to absorb the liquid they hold more precious than life, heedless of the agony whose last gestures almost are touching them, of the cries of distress that arise all around. And when the comb is empty, so great is their anxiety that nothing shall be lost, that their eagerness to gather the honey which clings to the victims will induce them tranquilly to climb over dead and dying, unmoved by the presence of the first and never dreaming of helping the others. In this case, therefore, they have no notion of the danger they run, 


\section{The Life of the Bee}

seeing that they are wholly untroubled by the death that is scattered about them, and they have not the slightest sense of solidarity or pity. As regards the danger, the explanation lies ready to hand; the bees know not the meaning of fear, and, with the exception only of smoke, are afraid of nothing in the world. Outside the hive, they display extreme condescension and forbearance. They will avoid whatever disturbs them, and affect to ignore its existence, so long as it come not too close; as though aware that this universe belongs to all, that each one has his place there, and must needs be discreet and peaceful. But beneath this indulgence is quietly hidden a heart so sure of itself that it never dreams of protesting. If they are threatened, they will alter their course, but never attempt to escape. In the hive, however, they will not confine themselves to this passive ignoring of peril. They 


\section{The Foundation of the City}

will spring with incredible fury on any living thing, ant or lion or man, that dares to profane the sacred ark. This we may term anger, ridiculous obstinacy, or heroism, according as our mind be disposed.

But of their want of solidarity outside the hive, and even of sympathy within it, I can find nothing to say. Are we to believe that each form of intellect possesses its own strange limitation, and that the tiny flame which with so much difficulty at last burns its way through inert matter and issues forth from the brain, is still so uncertain that if it illumine one point more strongly the others are forced into blacker darkness? Here we find that the bees (or nature acting within them) have organised work in common, the love and cult of the future, in a manner more perfect than can elsewhere be discovered. Is it for this reason that they have lost sight of all the 


\section{The Life of the Bee}

rest? They give their love to what lies ahead of them; we bestow ours on what is around. And we who love here, perhaps, have no love left for what is beyond. Nothing varies so much as the direction of pity or charity. We ourselves should formerly have been far less shocked than we are to-day at the insensibility of the bees; and to many an ancient people such conduct would not have seemed blameworthy. And further, can we tell how many of the things that we do would shock a being who might be watching us as we watch the bees? 
IV

THE LIFE OF THE BEE 


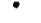




\section{IV}

\section{THE LIFE OF THE BEE}

$$
\text { [45] }
$$

I ET us now, in order to form a clearer conception of the bees' intellectual power, proceed to consider their methods of inter-communication. There can be no doubting that they understand each other; and indeed it were surely impossible for a republic so considerable, wherein the labours are so varied and so marvellously combined, to subsist amid the silence and spiritual isolation of so many thousand creatures. They must be able, therefore, to give expression to thoughts and feelings, by means either of a phonetic vocabulary or more prob- 


\section{The Life of the Bee}

ably of some kind of tactile language or magnetic intuition, corresponding perhaps to senses and properties of matter wholly unknown to ourselves. And such intuition well might lodge in the mysterious antennæ-containing, in the case of the workers, according to Cheshire's calculation, twelve thousand tactile hairs and five thousand "smell-hollows," wherewith they probe and fathom the darkness. For the mutual understanding of the bees is not confined to their habitual labours; the extraordinary also has a name and place in their language; as is proved by the manner in which news, good or bad, normal or supernatural, will at once spread in the hive; the loss or return of the mother, for instance, the entrance of an enemy, the intrusion of a strange queen, the approach of a band of marauders, the discovery of treasure, etc. And so characteristic is their attitude, so essentially 


\section{The Life of the Bee}

different their murmur at each of these special events, that the experienced apiarist can without difficulty tell what is troubling the crowd that moves distractedly to and fro in the shadow.

If you desire a more definite proof, you have but to watch a bee that shall just have discovered a few drops of honey on your window-sill or the corner of your table. She will immediately gorge herself with it; and so eagerly, that you will have time, without fear of disturbing her, to mark her tiny belt with a touch of paint. But this gluttony of hers is all on the surface; the honey will not pass into the stomach proper, into what we might call her personal stomach, but remains in the sac, the first stomach, - that of the community, if one may so express it. This reservoir full, the bee will depart, but not with the free and thoughtless motion of the fly or butterfly; she, on the contrary, will 


\section{The Life of the Bee}

for some moments fly backwards, hovering eagerly about the table or window, with her head turned toward the room.

She is reconnoitring, fixing in her memory the exact position of the treasure. Thereupon she will go to the hive, disgorge her plunder into one of the provision-cells, and in three or four minutes return, and resume operations at the providential window. And thus, while the honey lasts, will she come and go, at intervals of every five minutes, till evening, if need be; without interruption or rest; pursuing her regular journeys from the hive to the window, from the window back to the hive.

$$
\text { [46] }
$$

Many of those who have written on bees have thought fit to adorn the truth; I myself have no such desire. For studies of this description to possess 562 


\section{The Life of the Bee}

any interest, it is essential that they should remain absolutely sincere. $\mathrm{Had}$ the conclusion been forced upon me that bees are incapable of communicating to each other news of an event occurring outside the hive, I should, I imagine, as a set-off against the slight disappointment this discovery would have entailed, have derived some degree of satisfaction in recognising once more that man, after all, is the only truly intelligent being who inhabits our globe. And there comes too a period of life when we have more joy in saying the thing that is true than in saying the thing that merely is wonderful. Here as in every case the principle holds that, should the naked truth appear at the moment less interesting, less great and noble than the imaginary embellishment it lies in our power to bestow, the fault must rest with ourselves who still are unable to perceive the astonishing 163 


\section{The Life of the Bee}

relation in which this truth always must stand to our being, and to universal law; and in that case it is not the truth, but our intellect, that needs embellishment and ennoblement.

I will frankly confess, therefore, that the marked bee often returns alone. Shall we believe that in bees there exists the same difference of character as in men; that of them too some are gossips, and others prone to silence? A friend who stood by and watched my experiment, declared that it was evidently mere selfishness or vanity that caused so many of the bees to refrain from revealing the source of their wealth, and from sharing with others the glory of an achievement that must seem miraculous to the hive. These were sad vices indeed, which give not forth the sweet odour, so fragrant and loyal, that springs from the home of the many thousand sisters. But, what164 


\section{The Life of the Bee}

ever the cause, it often will also happen that the bee whom fortune has favoured will return to the honey accompanied by two or three friends. I am aware that Sir John Lubbock, in the appendix to his book on "Ants, Bees, and Wasps," records the results of his investigations in long and minute tables; and from these we are led to infer that it is a matter of rarest occurrence for a single bee to follow the one who has made the discovery. The learned naturalist does not name the race of bees which he selected for his experiments, or tell us whether the conditions were especially unfavourable. As for myself I only can say that my own tables, compiled with great care, - and every possible precaution having been taken that the bees should not be directly attracted by the odour of the honey, - establish that on an average one bee will bring others four times out of ten. 


\section{The Life of the Bee}

I even one day came across an extraordinary little Italian bee, whose belt I had marked with a touch of blue paint. In her second trip she brought two of her sisters, whom I imprisoned, without interfering with her. She departed once more, and this time returned with three friends, whom I again confined, and so till the end of the afternoon, when, counting my prisoners, I found that she had told the news to no less than eighteen bees.

In fact you will find, if you make this experiment yourself, that communication, if not general, at least is frequent. The possession of this faculty is so well known to American bee-hunters that they trade upon it when engaged in searching for nests. Mr. Josiah Emery remarks on this head (quoted by Romanes in his "Intellect of Animals"): "Going to a field or wood at a distance from 


\section{The Life of the Bee}

tame bees with their box of honey, they gather up from the flowers and imprison one or more bees, and after they have become sufficiently gorged, let them out to return to their home with their easily gotten load. Waiting patiently a longer or shorter time, according to the distance of the bee-tree, the hunter scarcely ever fails to see the bee or bees return accompanied by other bees, which are in like manner imprisoned till they in turn are filled; then one or more are let out at places distant from each other, and the direction in which the bee flies noted; and thus, by a kind of triangulation, the position of the bee-tree proximately ascertained."

$$
\text { [ } 47 \text { ] }
$$

You will notice too in your experiments that the friends who appear to obey the behests of good fortune do not 167 


\section{The Life of the Bee}

always fly together, and that there will often be an interval of several seconds between the different arrivals. As regards these communications, therefore, we must ask ourselves the question that Sir John Lubbock has solved as far as the ants are concerned.

Do the comrades who flock to the treasure only follow the bee that first made the discovery, or have they been sent on by her, and do they find it through following her indications, her description of the place where it lies? Between these two hypotheses, that refer directly to the extent and working of the bee's intellect, there is obviously an enormous difference. The English savant has succeeded, by means of an elaborate and ingenious arrangement of gangways, corridors, moats full of water, and flying bridges, in establishing that the ants in such cases do no more than follow in the track of the pioneering 168 


\section{The Life of the Bee}

insect. With ants, that can be made to pass where one will, such experiments are possible; but for the bee, whose wings throw every avenue open, some other expedient must of necessity be contrived. I imagined the following, which, though it gave no definite result, might yet, under more favourable conditions, and if organised more carefully, give rise to definite and satisfactory conclusions.

My study in the country is on the first floor, above a somewhat lofty room ; sufficiently high, therefore, to be out of the ordinary range of the bees' flight, except at times when the chestnuts and lime trees are in bloom. And for more than a week before I started this experiment I had kept on my table an open comb of honey, without the perfume having attracted, or induced the visit of, a single bee. Then I went to a glass hive that was close to the house, took an Italian I 69 


\section{The Life of the Bee}

bee, brought her to my study, set her on the comb, and marked her while she was feeding.

When satisfied, she flew away and returned to the hive. I followed, saw her pass over the surface of the crowd, plunge her head into an empty cell, disgorge her honey, and prepare to set forth again. At the door of the hive I had placed a glass box, divided by a trap into two compartments. The bee flew into this box; and as she was alone, and no other bee seemed to accompany or follow her, I imprisoned her and left her there. I then repeated the experiment on twenty different bees in succession. When the marked bee reappeared alone, I imprisoned her as I had imprisoned the first. But eight of them came to the threshold of the hive and entered the box accompanied by two or three friends. By means of the trap I was able to separate the marked bee 


\section{The Life of the Bee}

from her companions, and to keep her a prisoner in the first compartment. Then, having marked her companions with a different colour, I- threw open the second compartment and set them at liberty, myself returning quickly to my study to await their arrival. Now it is evident that if a verbal or magnetic communication had passed, indicating the place, describing the way, etc., a certain number of the bees, having been furnished with this information, should have found their way to my room. I am compelled to admit that there came but a single one. Was this mere chance, or had she followed instructions received? The experiment was insufficient, but circumstances prevented me from carrying it further. I released the "baited" bees, and my study soon was besieged by the buzzing crowd to whom they had taught the way to the treasure. 


\section{The Life of the Bee}

We need not concern ourselves with this incomplete attempt of mine, for many other curious traits compel us to recognise the existence among the bees of spiritual communications that go beyond a mere "yes" or "no," and that are manifest in cases where mere example or gesture would not be sufficient. Of such, for instance, are the remarkable harmony of their work in the hive, the extraordinary division of labour, the regularity with which one worker will take the place of another, etc. I have often marked bees that went foraging in the morning, and found that, in the afternoon, unless flowers were specially abundant, they would be engaged in heating and fanning the broodcells, or perhaps would form part of the mysterious, motionless curtain in whose midst the wax-makers and sculptors would be at work. Similarly I have noticed that workers whom I have seen gather- 


\section{The Life of the Bee}

ing pollen for the whole of one day, will bring no pollen back on the morrow, but will concern themselves exclusively with the search for nectar, and viceversa.

$$
\text { [48] }
$$

And further, we might mention what M. Georges de Layens, the celebrated French apiarist, terms the "Distribution of Bees over Melliferous Plants." Day after day, at the first hour of sunrise, the explorers of the dawn return, and the hive awakes to receive the good news of the earth. "The lime trees are blossoming to-day on the banks of the canal." "The grass by the roadside is gay with white clover." "The sage and the lotus are about to open." "The mignonette, the lilies are overflowing with pollen." Whereupon the bees must organise quickly, and arrange to divide the work. Five thou- 


\section{The Life of the Bee}

sand of the sturdiest will sally forth to the lime trees, while three thousand juniors go and refresh the white clover. Those who yesterday were absorbing nectar from the corollas will to-day repose their tongue and the glands of their sac, and gather red pollen from the mignonette, or yellow pollen from the tall lilies; for never shall you see a bee collecting or mixing pollen of a different colour or species; and indeed one of the chief pre-occupations of the hive is the methodical bestowal of these pollens in the store-rooms, in strict accordance with their origin and colour. Thus does the hidden genius issue its commands. The workers immediately sally forth, in long black files, whereof each one will fly straight to its allotted task. "The bees," says De Layens, "would seem to be perfectly informed as to the locality, the relative melliferous value, and the distance of every melliferous 


\section{The Life of the Bee}

plant within a certain radius from the hive.

"If we carefully note the different directions in which these foragers $\mathrm{fly}$, and observe in detail the harvest they gather from the various plants around, we shall find that the workers distribute themselves over the flowers in proportion not only to the numbers of flowers of one species, but also to their melliferous value. Nay, more - they make daily calculations as to the means of obtaining the greatest possible wealth of saccharine liquid. In the spring, for instance, after the willows have bloomed, when the fields still are bare, and the first flowers of the woods are the one resource of the bees, we shall see them eagerly visiting. gorse and violets, lungworts and anemones. But, a few days later, when fields of cabbage and colza begin to flower in sufficient abundance, we shall find that the bees will almost entirely 


\section{The Life of the Bee}

forsake the plants in the woods, though these be still in full blossom, and will confine their visits to the flowers of cabbage and colza alone. In this fashion they regulate, day by day, their distribution over the plants, so as to collect the greatest value of saccharine liquid in the least possible time.

"It may fairly be claimed, therefore, for the colony of bees that, in its harvesting labours no less than in its internal economy, it is able to establish a rational distribution of the number of workers without ever disturbing the principle of the division of labour."

$$
\text { [49] }
$$

But what have we to do, some will ask, with the intelligence of the bees? What concern is it of ours whether this be a little less or a little more? Why weigh, with such infinite care, a minute fragment of 


\section{The Life of the Bee}

almost invisible matter, as though it were a fluid whereon depended the destiny of man? I hold, and exaggerate nothing, that our interest herein is of the most considerable. The discovery of a sign of true intellect outside ourselves procures us something of the emotion Robinson Crusoe felt when he saw the imprint of a human foot on the sandy beach of his island. We seem less solitary than we had believed. And indeed, in our endeavour to understand the intellect of the bees, we are studying in them that which is most precious in our own substance : an atom of the extraordinary matter which possesses, wherever it attach itself, the magnificent power of transfiguring blind necessity, of organising, embellishing, and multiplying life; and, most striking of all, of holding in suspense the obstinate force of death, and the mighty, irresponsible wave that 


\section{The Life of the Bee}

wraps almost all that exists in an eternal unconsciousness.

Were we sole possessors of the particle of matter that, when maintained in a special condition of flower or incandescence, we term the intellect, we should to some extent be entitled to look on ourselves as privileged beings, and to imagine that in us nature achieved some kind of aim ; but here we discover, in the hymenoptera, an entire category of beings in whom a more or less identical aim is achieved. And this fact, though it decide nothing perhaps, still holds an honourable place in the mass of tiny facts that help to throw light on our position in this world. It affords even, if considered from a certain point of view, a fresh proof of the most enigmatic part of our being; for the superpositions of destinies that we find in the hive are surveyed by us from an eminence loftier than any we can attain 


\section{The Life of the Bee}

for the contemplation of the destsnies of man. There we see before us, in miniature, the large and simple lines that in our own disproportionate sphere we never have the occasion to disentangle and follow to the end. Spirit and matter are there, the race and the individual, evolution and permanence, life and death, the past and the future; all gathered together in a retreat that our hand can lift and one look of our eye embrace. And may we not reasonably ask ourselves whether the mere size of a body, and the room that it fills in time and space, can modify to the extent we imagine the secret idea of nature ; the idea that we try to discover in the little history of the hive, which in a few days already is ancient, no less than in the great history of man, of whom three generations overlap a long century? 


\section{The Life of the Bee}

\section{[50]}

Let us go on, then, with the story of our hive; let us take it up where we left it; and raise, as high as we may, a fold of the festooned curtain in whose midst a strange sweat, white as snow and airier than the down of a wing, is beginning to break over the swarm. For the wax that is now being born is not like the wax that we know; it is immaculate, it has no weight; seeming truly to be the soul of the honey, that itself is the spirit of flowers. And this motionless incantation has called it forth that it may serve us, later - in memory of its origin, doubtless, wherein it is one with the azure sky, and heavy with perfumes of magnificence and purity - as the fragrant light of the last of our altars. 


\section{The Life of the Bee}

\section{[5I]}

To follow the various phases of the secretion and employment of wax by a swarm that is beginning to build, is a matter of very great difficulty. All comes to pass in the blackest depths of the crowd, whose agglomeration, growing denser and denser, produces the temperature needful for this exudation, which is the privilege of the youngest bees. Huber, who was the first to study these phenomena, bringing incredible patience to bear and exposing himself at times to very serious danger, devotes to them more than two hundred and fifty pages; which, though of considerable interest, are necessarily somewhat confused. But I am not treating this subject technically; and while referring when necessary to Huber's admirable studies, I shall confine myself generally to relating what is 


\section{The Life of the Bee}

patent to any one who may gather a swarm into a glass hive.

We have to admit, first of all, that we know not yet by what process of alchemy the honey transforms itself into wax in the enigmatic bodies of our suspended bees. We can only say that they will remain thus suspended for a period extending from eighteen to twenty-four hours, in a temperature so high that one might almost believe that a fire was burning in the hollow of the hive; and then white and transparent scales will appear at the opening of four little pockets that every bee has underneath its abdomen.

When the bodies of most of those who form the inverted cone have thus been adorned with ivory tablets, we shall see one of the bees, as though suddenly inspired, abruptly detach herself from the mass, and climb over the backs of the passive crowd till she reach the inner 182 


\section{The Life of the Bee}

pinnacle of the cupola. To this she will fix herself solidly, dislodging, with repeated blows of her head, such of her neighbours as may seem to hamper her movements. Then, with her mouth and claws, she will seize one of the eight scales that hang from her abdomen, and at once proceed to clip it and plane it, extend it, knead it with her saliva, bend it and flatten it, roll it and straighten it, with the skill of a carpenter handling a pliable panel. When at last the substance, thus treated, appears to her to possess the required dimensions and consistency, she will attach it to the highest point of the dome, thus laying the first, or rather the keystone of the new town; for we have here an inverted city, hanging down from the sky, and not rising from the bosom of earth like a city of men.

To this keystone, depending in the 183 


\section{The Life of the Bee}

void, she will add other fragments of wax that she takes in succession from beneath her rings of horn; and finally, with one last lick of the tongue, one last wave of antennæ, she will go as suddenly as she came, and disappear in the crowd. Another will at once take her plàce, continue the work at the point where the first one has left it, add on her own, change and adjust whatever may seem to offend the ideal plan of the tribe, then vanish in her turn, to be succeeded by a third, a fourth, and a fifth, all appearing unexpectedly, suddenly, one after the other, none completing the work, but each bringing her share to the task in which all combine.

$$
\text { [ } \left.5^{2}\right]
$$

A small block of wax, formless as yet, hangs down from the top of the vault. So soon as its thickness may be deemed sufficient, we shall see another bee emerge 


\section{The Life of the Bee}

from the mass, her physical appearance differing appreciably from that of the foundresses who preceded her. And her manner displays such settled conviction, her movements are followed so eagerly by all the crowd, that we almost might fancy that some illustrious engineer had been summoned to trace in the void the site of the first cell of all, from which every other must mathematically depend. This bee belongs to the sculptor or carver class of workers; she produces no wax herself and is content to deal with the materials others provide. She locates the first cell, scoops into the block for an instant, lays the wax she has removed from the cavity on the borders around it; and then, like the foundresses, abruptly departs and abandons her model. Her place is taken at once by an impatient worker, who continues the task that a third will finish, while others close by are 


\section{The Life of the Bee}

attacking the rest of the surface and the opposite side of the wall; each one obeying the general law of interrupted and successive labour, as though it were an inherent principle of the hive that the pride of toil should be distributed, and every achievement be anonymous and common to all, that it might thereby become more fraternal.

$$
\text { [53] }
$$

The outline of the nascent comb may soon be divined. In form it will still be lenticular, for the little prismatic tubes that compose it are unequal in length, and diminish in proportion as they recede from the centre to the extremities. In thickness and appearance at present it more or less resembles a human tongue whose sides might be formed of hexagonal cells, contiguous, and placed back to back.

The first cells having been built, the 186 


\section{The Life of the Bee}

foundresses proceed to add a second block of wax to the roof; and so in gradation a third and a fourth. These blocks follow each other at regular intervals so nicely calculated that when, at a much later period, the comb shall be fully developed, there will be ample space for the bees to move between its parallel walls.

Their plan must therefore embrace the final thickness of every comb, which will be from eighty-eight to ninety-two hundredths of an inch, and at the same time the width of the avenues between, which must be about half an inch, or in other words twice the height of a bee, since there must be room to pass back to back between the combs.

The bees, however, are not infallible, nor does their certainty appear mechanical. They will commit grave errors at times, when circumstances present unusual difficulty. They will often leave too much 187 


\section{The Life of the Bee}

space, or too little, between the combs. This they will remedy as best they can, either by giving an oblique twist to the comb that too nearly approaches the other, or by introducing an irregular comb into the gap. "The bees sometimes make mistakes," Réaumur remarks on this subject, " and herein we may find yet another fact which appears to prove that they reason."

\section{[54]}

We know that the bees construct four kinds of cells. First of all, the royal cells, which are exceptional, and contrived somewhat in the shape of an acorn; then the large cells destined for the rearing of males and storing of provisions when flowers super-abound; and the small cells, serving as workers' cradles and ordinary store-rooms, which occupy normally about four-fifths of the built-over surface of the I 88 


\section{The Life of the Bee}

hive. And lastly, so as to connect in orderly fashion the larger cells with the small, the bees will erect a certain number of what are known as transition cells. These must of necessity be irregular in form; but so unerringly accurate are the dimensions of the second and third types that, at the time when the decimal system was established, and a fixed measure sought in nature to serve as a starting-point and an incontestable standard, it was proposed by Réaumur to select for this purpose the cell of the bee. ${ }^{1}$

Each of the cells is an hexagonal tube

1 It was as well, perhaps, that this standard was not adopted. For although the diameter of the cells is admirably regular, it is, like all things produced by a living organism, not matbematically invariable in the same hive. Further, as M. Maurice Girard has pointed out, the apothem of the cell varies among different races of bees, so that the standard would alter from hive to hive, according to the species of bee that inhabited it. 


\section{The Life of the Bee}

placed on a pyramidal base; and two layers of these tubes form the comb, their bases being opposed to each other in such fashion that each of the three rhombs or lozenges which on one side constitute the pyramidal base of one cell, composes at the same time the pyramidal base of three cells on the other. It is in these prismatic tubes that the honey is stored; and to prevent its escaping during the period of maturation, - which would infallibly happen if the tubes were as strictly horizontal as they appear to be, - the bees incline them slightly, to an angle of $4^{\circ}$ or $5^{\circ}$.

"Besides the economy of wax," says Réaumur, when considering this marvellous construction in its entirety, "besides the economy of wax that results from the disposition of the cells, and the fact that this arrangement allows the bees to fill the comb without leaving a single spot vacant, 


\section{The Life of the Bee}

there are other advantages also with respect to the solidity of the work. The angle at the base of each cell, the apex of the pyramidal cavity, is buttressed by the ridge formed by two faces of the hexagon of another cell. The two triangles, or extensions of the hexagon faces which fill one of the convergent angles of the cavity enclosed by the three rhombs, form by their junction a plane angle on the side they touch; each of these angles, concave within the cell, supports, on its convex side, one of the sheets employed to form the hexagon of another cell; the sheet, pressing on this angle, resists the force which is tending to push it outwards; and in this fashion the angles are strengthened. Every advantage that could be desired with regard to the solidity of each cell is procured by its own formation and its position with reference to the others." 


\section{The Life of the Bee}

\section{[55]}

"There are only," says Dr. Reid, " three possible figures of the cells which can make them all equal and similar, without any useless interstices. These are the equilateral triangle, the square, and the regular hexagon. Mathematicians know that there is not a fourth way possible in which a plane shall be cut into little spaces that shall be equal, similar, and regular, without useless spaces. Of the three figures, the hexagon is the most proper for convenience and strength. Bees, as if they knew this, make their cells regular hexagons.

"Again, it has been demonstrated that, by making the bottoms of the cells to consist of three planes meeting in a point, there is a saving of material and labour in no way inconsiderable. The bees, as if acquainted with these principles of solid 


\section{The Life of the Bee}

geometry, follow them most accurately. It is a curious mathematical problem at what precise angle the three planes which compose the bottom of a cell ought to meet, in order to make the greatest possible saving, or the least expense of material and labour. ${ }^{1}$ This is one of the

1 Réaumur suggested the following problem to the celebrated mathematician Koenig: "Of all possible heragonal cells with pyramidal base composed of three equal and similar rhombs, to find the one whose construction would need the least material." Koenig's answer was, the cell that had for its base three rhombs whose large angle was $109^{\circ} 26^{\prime \prime}$, and the small $70^{\circ}$ $34^{\prime \prime}$. Another savant, Maraldi, had measured as exactly as possible the angles of the rhombs constructed by the bees, and discovered the larger to be $109^{\circ} 28^{\prime \prime}$, and the other $70^{\circ} 32^{\prime \prime}$. Between the two solutions there was a difference, therefore, of only $z^{\prime \prime}$. It is probable that the error, if error there be, should be attributed to Maraldi rather than to the bees; for it is impossible for any instrument to measure the angles of the cells, which are not very clearly defined, with infallible precision.

The problem suggested to Koenig was put to 


\section{The Life of the Bee}

problems which belong to the higher parts of mathematics. It has accordingly been resolved by some mathematicians, particularly by the ingenious Maclaurin, by a fluctionary calculation which is to be found in the Transactions of the Royal Society of London. He has determined precisely the angle required, and he found, by the most exact mensuration the subject would admit, that it is the very angle in which the three planes at the bottom of the cell of a honey comb do actually meet."

\section{[56]}

I myself do not believe that the bees indulge in these abstruse calculations; but, on the other hand, it seems equally impossible to me that such astounding re-

another mathematician, Cramer, whose solution came even closer to that of the bees, viz., $109^{\circ} 28 \mathrm{z} / \mathrm{z}^{\prime \prime}$ for the large angle, and $70^{\circ} 31 / 2$ " for the small. 


\section{The Life of the Bee}

sults can be due to chance alone, or to the mere force of circumstance. The wasps, for instance, also build combs with hexagonal cells, so that for them the problem was identical, and they have solved it in a far less ingenious fashion. Their combs have only one layer of cells, thus lacking the common base that serves the bees for their two opposite layers. The wasps' comb, therefore, is not only less regular, but also less substantial ; and so wastefully constructed that, besides loss of material, they must sacrifice about a third of the available space and a quarter of the energy they put forth. Again, we find that the trigonæ and meliponæ, which are veritable and domesticated bees, though of less advanced civilisation, erect only one row of rearing-cells, and support their horizontal, superposed combs on shapeless and costly columns of wax. Their provisioncells are merely great pots, gathered to- 


\section{The Life of the Bee}

gether without any order; and, at the point between the spheres where these might have intersected and induced a profitable economy of space and material, the meliponæ clumsily insert a section of cells with flat walls. Indeed, to compare one of their nests with the mathematical cities of our own honey-flies, is like imagining a hamlet composed of primitive huts side by side with a modern town; whose ruthless regularity is the logical, though perhaps somewhat charmless, result of the genius of man, that to-day, more fiercely than ever before, seeks to conquer space, matter, and time.

$$
\text { [57] }
$$

There is a theory, originally propounded by Buffon and now revived, which assumes that the bees have not the least intention of constructing hexagons with a pyramidal base, but that their 196 


\section{The Life of the Bee}

desire is merely to contrive round cells in the wax; only, that as their neighbours, and those at work on the opposite side of the comb, are digging at the same moment and with the same intentions, the points where the cells meet must of necessity become hexagonal. Besides, it is said, this is precisely what happens to crystals, the scales of certain kinds of fish, soap-bubbles, etc., as it happens in the following experiment that Buffon suggested. "If," he said, "you fill a dish with peas or any other cylindrical bean, pour as much water into it as the space between the beans will allow, close it carefully and then boil the water, you will find that all these cylinders have become six-sided columns. And the reason is evident, being indeed purely mechanical ; each of the cylindrical beans tends, as it swells, to occupy the utmost possible space within a given space; wherefore it 


\section{The Life of the Bee}

follows that the reciprocal compression compels them all to become hexagonal. Similarly each bee seeks to occupy the utmost possible space within a given space, with the necessary result that, its body being cylindrical, the cells become hexagonal for the same reason as before, viz., the working of reciprocal obstacles."

$$
\text { [ } \left.5^{8}\right]
$$

These reciprocal obstacles, it would seem, are capable of marvellous achievement; on the same principle, doubtless, that the vices of man produce a general virtue, whereby the human race, hateful often in its individuals, ceases to be so in the mass. We might reply, first of all, with Brougham, Kirby and Spence, and others, that experiments with peas and soap-bubbles prove nothing; for the reason that in both cases the pressure produces only irregular forms, and in no 


\section{The Life of the Bee}

wise explains the existence of the pris. matic base of the cells. But above all we might answer that there are more ways than one of dealing with rigid necessity; that the wasp, the humble-bee, the trigonæ and meliponæ of Mexico and Brazil achieve very different and manifestly inferior results, although the circumstances, and their own intentions, are absolutely identical with those of the bees. It might further be urged that if the bee's cell does indeed follow the law that governs crystals, snow, soap-bubbles, as well as Buffon's boiled peas, it also, through its general symmetry, disposition in opposite layers, and angle of inclination, obeys many other laws that are not to be found in matter. May we not say, too, of man that all his genius is comprised in his fashion of handling kindred necessities? And if it appear to us that his manner of treating these is the best 


\section{The Life of the Bee}

there can possibly be, the reason only can lie in the absence of a judge superior to ourselves. But it is well that argument should make way for fact; and indeed, to the objection based on an experiment, the best reply of all must be a counter-experiment.

In order to satisfy myself that hexagonal architecture truly was written in the spirit of the bee, I cut off and removed one day a disc of the size of a fivefranc piece from the centre of a comb, at a spot where there were both broodcells and cells full of honey. I cut into the circumference of this disc, at the intersecting point of the pyramidal cells; inserted a piece of tin on the base of one of these sections, shaped exactly to its dimensions, and possessed of resistance sufficient to prevent the bees from bending or twisting it. Then I replaced the slice of comb, duly furnished with its 


\section{The Life of the Bee}

slab of tin, on the spot whence I had removed it; so that, while one side of the comb presented no abnormal feature, the damage having been repaired, the other displayed a sort of deep cavity, covering the space of about thirty cells, with the piece of tin as its base. The bees were disconcerted at first; they flocked in numbers to inspect and examine this curious chasm; day after day they wandered agitatedly to and fro, apparently unable to form a decision. But, as I fed them copiously every evening, there came a moment when they had no more cells available for the storage of provisions. Thereupon they probably summoned their great engineers, distinguished sculptors, and wax-workers, and invited them to turn this useless cavity to profitable account.

The wax-makers having gathered around and formed themselves into a dense fes- 


\section{The Life of the Bee}

toon, so that the necessary heat might be maintained, other bees descended into the hole and proceeded solidly to attach the metal, and connect it with the walls of adjacent cells, by means of little waxen hooks which they distributed regularly over its surface. In the upper semicircle of the disc they then began to construct three or four cells, uniting these to the hooks. Each of these transition, or accommodation, cells was more or less deformed at the top, to allow of its being soldered to the adjoining cell on the comb; but its lower portion already designed on the tin three very clear angles, whence there ran three little straight lines that correctly indicated the first half of the following cell.

After forty-eight hours, and notwithstanding the fact that only three bees at a time were able to work in the cavity, the entire surface of the tin was covered 


\section{The Life of the Bee}

with outlined cells. These were less regular, certainly, than those of an ordinary comb; wherefore the queen, having inspected them, wisely declined to lay any eggs there, for the generation that would have arisen therefrom would necessarily have been deformed. Each cell, however, was a perfect hexagon; nor did it contain a single crooked line, a single curved figure or angle. And yet the ordinary conditions had all been changed; the cells had neither been scooped out of a block, according to Huber's description, nor had they been designed within a waxen hood, and, from being circular at first, been subsequently converted into hexagons by the pressure of adjoining cells, as explained by Darwin. Neither could there be question here of reciprocal obstacles, the cells having been formed one by one, and their first lines traced on what practically was a bare table. It would 


\section{The Life of the Bee}

seem incontestable, therefore, that the hexagon is not merely the result of mechanical necessities, but that it has its true place in the plans, the experience, the intellect and will of the bee. I may relate here another curious instance of the workers' sagacity : the cells they built on the tin had no other base than the metal itself. The engineers of the corps had evidently decided that the tin could adequately retain the honey; and had considered that, the substance being impermeable, they need not waste the material they value so highly by covering the metal with a layer of wax. But, a short time after, some drops of honey having been placed in two of these cells, the bees discovered, in tasting it, that the contact of the metal had a deteriorating effect. Thereupon they reconsidered the matter, and covered over with wax the enrire surface of the tin. 


\section{The Life of the Bee}

\section{[59]}

Were it our desire to throw light upon all the secrets of this geometric architecture, we should have more than one curious question still to consider; as for instance the shape of the first cells, which, being attached to the roof, are modified in such a manner as to touch the roof at the greatest possible number of points.

The design of the principal thoroughfares is determined by the parallelism of the combs; but we must admire the ingenious construction of alleys and gangways through and around the comb, so skilfully contrived as to provide short cuts in every direction and prevent congestion of traffic, while ensuring free circulation of air. And finally we should have to study the construction of transition cells, wherein we see a unanimous instinct 


\section{The Life of the Bee}

at work that impels the bees at a given moment to increase the size of their dwellings. Three reasons may dictate this step: an extraordinary harvest may call for larger receptacles, the workers may consider the population to be sufficiently numerous, or it may have become necessary that males should be born. Nor can we in such cases refrain from wondering at the ingenious economy, the unerring, harmonious conviction, with which the bees will pass from the small to the large, from the large to the small; from perfect symmetry to, where unavoidable, its very reverse, returning to ideal regularity so soon as the laws of a live geometry will allow; and all the time not losing a cell, not suffering a single one of their numerous structures to be sacrificed, to be ridiculous, uncertain, or barbarous, or any section thereof to become unfit for use. But I fear that I have already wandered 206 


\section{The Life of the Bee}

into many details that will have but slen. der interest for the reader, whose eyes perhaps may never have followed a flight of bees; or who may have regarded them only with the passing interest with which we are all of us apt to regard the flower, the bird or the precious stone, asking of these no more than a slight superficial assurance, and forgetting that the most trivial secret of the non-human object we behold in nature connects more closely perhaps with the profound enigma of our origin and our end, than the secret of those of our passions that we study the most eagerly and the most passionately.

$$
\text { [60] }
$$

And I will pass over too - in my desire that this essay shall not become too didactic - the remarkable instinct that induces the bees at times to thin and demolish the extremity of their combs, when 207 


\section{The Life of the Bee}

these are to be enlarged or lengthened; though it must be admitted that in this case the "blind building instinct" fails signally to account for their demolishing in order that they may rebuild, or undoing what has been done that it may be done afresh, and with more regularity. I will content myself also with a mere reference to the remarkable experiment that enables us, with the aid of a piece of glass, to compel the bees to start their combs at a right angle; when they most ingeniously contrive that the enlarged cells on the convex side shall coincide with the reduced cells on the concave side of the comb.

But before finally quitting this subject let us pause, though it be but for an instant, and consider the mysterious fashion in which they manage to act in concert and combine their labour, when simultaneously carving two opposite sides of a comb, and unable therefore to see each 


\section{The Life of the Bee}

other. Take a finished comb to the light, fix your eyes on the diaphanous wax; you will see, most clearly designed, an entire network of sharply cut prisms, a whole system of concordances so infallible that one might almost believe them to be stamped on steel.

I wonder whether those who never have seen the interior of a hive can form an adequate conception of the arrangement and aspect of the combs. Let them imaginewe will take a peasant's hive, where the bee is left entirely to its own resources-let them imagine a dome of straw or osier, divided from top to bottom by five, six, eight, sometimes ten, strips of wax, resembling somewhat great slices of bread, that run in strictly parallel lines from the top of the dome to the floor, espousing closely the shape of the ovoid walls. Between these strips is contrived a space of about half an inch, to enable the bees to stand 


\section{The Life of the Bee}

and to pass each other. At the moment when they begin to construct one of these strips at the top of the hive, the waxen wall (which is its rough model, and will later be thinned and extended) is still very thick, and completely excludes the fifty or sixty bees at work on its inner face from the fifty or sixty simultaneously engaged in carving the outer, so that it is wholly impossible for one group to see the other, unless indeed their sight be able to penetrate opaque matter. And yet there is not a hole that is scooped on the inner surface, not a fragment of wax that is added, but corresponds with mathematical precision to a protuberance or cavity on the outer surface, and vice versa. How does this happen? How is it that one does not dig too deep, another not deep enough? Whence the invariable magical coincidence between the angles of the lozenges? What is it tells the bees that 


\section{The Life of the Bee}

at this point they must begin, and at that point stop? Once again we must content ourselves with the reply, that is no reply: "It is a mystery of the hive."

Huber has sought to explain this mystery by suggesting that the pressure of the bees' hooks and teeth may possibly produce slight projections, at regular intervals, on the opposite side of the comb ; or that they may be able to estimate the thickness of the block by the flexibility, elasticity, or some other physical quality of the wax; or again, that their antennæ, which seem so well adapted for the questioning of the finer, less evident side of things, may serve as a compass in the invisible; or, lastly, that the position of every cell may derive mathematically from the arrangement and dimensions of the cells on the first row, and thus dispense with the need for further measurement. But these explanations are evidently in- 


\section{The Life of the Bee}

sufficient; the first are mere hypotheses that cannot be verified, the others do no more than transplant the mystery. And useful as it may be to transplant mystery as often as we possibly can, it were not wise to imagine that a mystery has ceased to be because we have shifted its home.

$$
\text { [6I ] }
$$

Now let us leave these dreary building grounds, this geometrical desert of cells. The combs have been started, and are becoming habitable. Though it be here the infinitely little that, without apparent hope, adds itself to the infinitely little; though our eye with its limited vision look and see nothing, the work of wax, halting neither by day nor by night, will advance with incredible quickness. The impatient queen already has more than once paced the stockades that gleam white 


\section{The Life of the Bee}

in the darkness; and no sooner is the first row of dwellings complete than she takes possession with her escort of counsellors, guardians, or servants - for we know not whether she lead or be led, be venerated or supervised. When the spot. has been reached that she, or her urgent advisers, may regard as favourable, she arches her back, bends forward, and introduces the extremity of her long spindleshaped abdomen into one of the cells; the little eager heads of her escort meanwhile forming a passionate circle around her, watching her with their enormous black eyes, supporting her, caressing her wings, and waving their feverish antennæ as though to encourage, incite, or congratulate.

You may easily discover the spot where the queen shall be found by the sort of starry cockade, or oval brooch perhaps of the imposing kind our grandmothers used to wear, of which she forms the 


\section{The Life of the Bee}

central stone. And one may mention here the curious fact that the workers always avoid turning their back on the queen. No sooner has she approached a group than they will invariably arrange themselves so as to face her with eyes and antennæ, and to walk backwards before her. It is a token of respect, or of solicitude, that, unlikely as it may seem, is nevertheless constant and general. But to return to the queen. During the slight spasm that visibly accompanies the emission of an egg, one of her daughters will often throw her arms round her and appear to be whispering to her, brow pressed to brow and mouth to mouth. But the queen, in no wise disturbed by this somewhat bold demonstration, takes her time, tranquilly, calmly, wholly absorbed by the mission that would seem amorous delight to her rather than labour. And after some seconds she will rise, very 


\section{The Life of the Bee}

quietly, take a step back, execute a slight turn on herself, and proceed to the next cell, into which she will first, before introducing her abdomen, dip her head to make sure that all is in order and that she is not laying twice in the same cell; and in the meanwhile two or three of her escort will have plunged into the cell she has quitted to see whether the work be duly accomplished, and to care for, and tenderly house, the little bluish egg she has laid.

From this moment, up to the first frosts of autumn, she does not cease laying; she lays while she is being fed, and even in her sleep, if indeed she sleeps at all, she still lays. She represents henceforth the devouring force of the future, which invades every corner of the kingdom. Step by step she pursues the unfortunate -workers who are exhaustedly, feverishly erecting the cradles her fecundity de- 


\section{The Life of the Bee}

mands. We have here the union of two mighty instincts; and their workings throw into light, though they leave unresolved, many an enigma of the hive.

It will happen, for instance, that the workers will distance her, and acquire a certain start; whereupon, mindful of their duties as careful housewives to provide for the bad days ahead, they hasten to fill with honey the cells they have wrested from the avidity of the species. But the queen approaches; material wealth must give way to the scheme of nature; and the distracted workers are compelled with all speed to remove the importunate treasure.

But assume them to be a whole comb ahead, and to have no longer before them her who stands for the tyranny of days they shall none of them see; we find then that they eagerly, hurriedly, build a zone of large cells, cells for males; 


\section{The Life of the Bee}

whose construction is very much easier, and far more rapid. When the queen in her turn attains this unthankful zone, she will regretfully lay a few eggs there, then cease, pass beyond, and clamour for more workers' cells. Her daughters obey; little by little they reduce the cells; and then the pursuit starts afresh, till at last the insatiable mother shall have traversed the whole circumference of the hive, and have returned to the first cells. These, by this time, will be empty; for the first generation will have sprung into life, soon to go forth, from their shadowy corner of birth, disperse over the neighbouring blossoms, people the rays of the sun and quicken the smiling hours; and then sacrifice themselves in their turn to the new generations that are already filling their place in the cradles. 


\section{The Life of the Bee}

$$
\text { [62] }
$$

And whom does the queen-bee obey? She is ruled by nourishment given her; for she does not take her own food, but is fed like a child by the very workers whom her fecundity harasses. And the food these workers deal out is nicely proportioned to the abundance of flowers, to the spoil brought back by those who visit the calyces. Here, then, as everywhere else in the world, one part of the circle is wrapped in darkness; here, as everywhere, it is from without, from an unknown power, that the supreme order issues; and the bees, like ourselves, obey the nameless lord of the wheel that incessantly turns on itself, and crushes the wills that have set it in motion.

Some little time back, I conducted a friend to one of my hives of glass, and showed him the movements of this wheel, 


\section{The Life of the Bee}

which was as readily perceptible as the great wheel of a clock; showed him, in all its "bareness, the universal agitation on every comb, the perpetual, frantic, bewildered haste of the nurses around the brood-cells; the living gangways and ladders formed by the makers of wax, the abounding, unceasing activity of the entire population, and their pitiless, useless effort; the ardent, feverish coming and going of all, the general absence of sleep save in the cradles alone, around which continuous labour kept watch; the denial of even the repose of death in a home which permits no illness and accords no grave; and my friend, his astonishment over, soon turned his eyes away, and in them I could read the signs of I know not what saddened fear.

And truly, underlying the gladness that we note first of all in the hive, underlying the dazzling memories of beautiful 


\section{The Life of the Bee}

days that render it the storehouse of summer's most precious jewels, underlying the blissful journeys that knit it so close to the flowers and to running water, to the sky, to the peaceful abundance of all that makes for beauty and happiness - underlying all these exterior joys, there reposes a sadness as deep as the eye of man can behold. And we, who dimly gaze on these things with our own blind eyes, we know full well that it is not they alone that we are striving to see, not they alone that we cannot understand, but that before us there lies a pitiable form of the great power that quickens us also.

Sad let it be, as all things in nature are sad, when our eyes rest too closely upon them. And thus it ever shall be so long as we know not her secret, know not even whether secret truly there be. And, should we discover some day that there is no secret, 


\section{The Life of the Bee}

or that the secret is monstrous, other duties will then arise that, as yet, perhaps, have no name. Let our heart, if it will, in the meanwhile repeat, "It is sad;" but let our reason be content to add, "Thus it is." At the present hour the duty before us is to seek out that which perhaps may be hiding behind these sorrows; and, urged on by this endeavour, we must not turn our eyes away, but steadily, fixedly, watch these sorrows and study them, with a courage and interest as keen as though they were joys. It is right that before we judge nature, before we complain, we should at least ask every question that we can possibly ask.

$$
\text { [63] }
$$

We have seen that the workers, when free for the moment from the threatening fecundity of the queen, hasten to erect cells for provisions, whose construction is 


\section{The Life of the Bee}

more economical and capacity greater. We have seen, too, that the queen prefers to lay in the smaller cells, for which she is incessantly clamouring. When these are wanting, however, or till they be provided, she resigns herself to laying her eggs in the large cells she finds on her road.

These eggs, though absolutely identical with those from which workers are hatched, will give birth to males, or drones. Now, conversely to what takes place when a worker is turned into queen, it is here neither the form nor the capacity of the cell that produces this change; for from an egg laid in a large cell and afterwards transferred to that of a worker (a most difficult operation, because of the microscopic minuteness and extreme fragility of the egg, but one that I have four or five times successfully accomplished) there will issue an undeniable male, though more or less atrophied. It 


\section{The Life of the Bee}

follows, therefore, that the queen must possess the power, while laying, of knowing or determining the sex of the egg, and of adapting it to the cell over which she is bending. She will rarely make a mistake. How does she contrive, from among the myriad eggs her ovaries contain, to separate male from female, and lower them, at will, into the unique oviduct?

Here, yet again, there confronts us an enigma of the hive; and in this case one of the most unfathomable. We know that the virgin queen is not sterile; but the eggs that she lays will produce only males. It is not till after the impregnation of the nuptial flight that she can produce workers or drones at will. The nuptial flight places her permanently in possession, till death, of the spermatozoa torn from her unfortunate lover. These spermatozoa, whose number Dr. Leuckart 


\section{The Lite of the Bee}

estimates at twenty-five millions, are preserved alive in a special gland known as the spermatheca, that is situate under the ovaries, at the entrance to the common oviduct. It is imagined that the narrow aperture of the smaller cells, and the manner in which the form of this aperture compels the queen to bend forward, exercise a certain pressure upon the spermatheca, in consequence of which the spermatozoa spring forth and fecundate the egg as it passes. In the large cells this pressure would not take place, and the spermatheca would therefore not open. Others, again, believe that the queen has perfect control over the muscles that open and close the spermatheca on the vagina; and these muscles are certainly very numerous, complex, and powerful. For myself, I incline to the second of these hypotheses, though I do not for a moment pretend to decide which is the more 


\section{The Life of the Bee}

correct; for indeed, the further we go and the more closely we study, the more plainly is it brought home to us that we merely are waifs shipwrecked on the ocean of nature; and ever and anon, from a sudden wave that shall be more transparent than others, there leaps forth a fact that in an instant confounds all we imagined we knew. But the reason of my preferring the second theory is that, for one thing, the experiments of a Bordeaux bee-keeper, M. Drory, have shown that in cases where all the large cells have been removed from the hive, the mother will not hesitate, when the moment for laying male eggs has come, to deposit these in workers' cells; and that, inversely, she will lay workers' eggs in cells provided for males, if she have no others at her disposal. And, further, we learn from the interesting observations of $\mathbf{M}$. Fabre on the Osmiz, which are wild and 


\section{The Life of the Bee}

solitary bees of the Gastrilegidæ family, that not only does the Osmia know in advance the sex of the egg she will lay, but that this sex is "optional for the mother, who decides it in accordance with the space of which she disposes; this space being often governed by chance and not to be modified; and she will deposit a male egg here and a female there." I shall not enter into the details of the great French entomologist's experiments, for they are exceedingly minute, and would take us too far. But whichever be the hypothesis we prefer to accept, either will serve to explain the queen's inclination to lay her eggs in workers' cells, without it being necessary to credit her with the least concern for the future.

It is not impossible that this slavemother, whom we are inclined to pity, may be indeed a great amorist, a great voluptuary, deriving a certain enjoyment, an 


\section{The Life of the Bee}

after-taste, as it were, of her one marriage-flight, from the union of the male and female principle that thus comes to pass in her being. Here again nature, never so ingenious, so cunningly prudent and diverse, as when contriving her snares of love, will not have failed to provide a certain pleasure as a bait in the interest of the species. And yet let us pause for a moment, and not become the dupes of our own explanation. For indeed, to attribute an idea of this kind to nature, and regard that as sufficient, is like flinging a stone into an unfathomable gulf we may find in the depths of a grotto, and imagining that the sounds it creates as it falls shall answer our every question, or reveal to us aught beside the immensity of the abyss.

When we say to ourselves, "This thing is of nature's devising; it is she has ordained this marvel; those are her desires 


\section{The Life of the Bee}

that we see before us!" the fact is merely that our special attention has been drawn to some tiny manifestation of life upon the boundless surface of matter that we deem inactive, and choose to describe, with evident inaccuracy, as nothingness and death. A purely fortuitous chain of events has allowed this special manifestation to attract our attention; but a thousand others, no less interesting, perhaps, and informed with no less intelligence, have vanished, not meeting with a like good-fortune, and have lost for ever the chance of exciting our wonder. It were rash to affirm aught beside; and all that remains, our reflections, our obstinate search for the final cause, our admiration and hopes - all these in truth are no more than our feeble cry as, in the depths of the unknown, we clash against what is more unknowable still; and this feeble cry declares the highest degree of indi228 


\section{The Life of the Bee}

vidual existence attainable for us on this mute and impenetrable surface, even as the flight of the condor, the song of the nightingale, reveal to them the highest degree of existence their species allows. But the evocation of this feeble cry, whenever opportunity offers, is none the less one of our most unmistakable duties; nor should we let ourselves be discouraged by its apparent futility. 



\section{V}

\section{THE YOUNG QUEENS}





\section{V}

\section{THE YOUNG QUEENS}

$$
\text { [64] }
$$

E ERE let us close our hive, where we 1 find that life is reassuming its circular movement, is extending and multiplying, to be again divided as soon as it shall attain the fulness of its happiness and strength; and let us for the last time reopen the mother-city, and see what is happening there after the departure of the swarm.

The tumult having subsided, the hapless city, that two thirds of her children have abandoned for ever, becomes feeble, empty, moribund; like a body from which the blood has been drained. Some thousands of bees have remained, however ; and 


\section{The Life of the Bee}

these, though a trifle languid perhaps, are still immovably faithful to the duty a precise destiny has laid upon them, still conscious of the part that they have themselves to play; they resume their labours, therefore, fill as best they can the place of those who have gone, remove all trace of the orgy, carefully house the provisions that have escaped pillage, sally forth to the flowers again, and keep scrupulous guard over the hostages of the future.

And for all that the moment may appear gloomy, hope abounds wherever the eye may turn. We might be in one of the castles of German legend, whose walls are composed of myriad phials containing the souls of men about to be born. For we are in the abode of life that goes before life. On all sides, asleep in their closely sealed cradles, in this infinite superposition of marvellous six-sided cells, lie thousands of nymphs, whiter than 


\section{The Young Queens}

milk, who with folded arms and head bent forward await the hour of awakening. In their uniform tombs, that, isolated, become nearly transparent, they seem almost like hoary gnomes, lost in deep thought, or legions of virgins whom the folds of the shroud have contorted, who are buried in hexagonal prisms that some inflexible geometrician has multiplied to the verge of delirium.

Over the entire area that the vertical walls enclose, and in the midst of this growing world that so soon shall transform itself, that shall four or five times in succession assume fresh vestments, and then spin its own winding-sheet in the shadow, hundreds of workers are dancing and flapping their wings. They appear thus to generate the necessary heat, and accomplish some other object besides that is still more obscure; for this dance of theirs contains some extraordinary move- 


\section{The Life of the Bee}

ments, so methodically conceived that they must infallibly answer some purpose which no observer has as yet, I believe, been able to divine.

A few days more, and the lids of these myriad urns - whereof a considerable hive will contain from sixty to eighty thousand -will break, and two large and earnest black eyes will appear, surmounted by antennæ that already are groping at life; while active jaws are busily engaged in enlarging the opening from within. The nurses at once come running; they help the young bee to emerge from her prison, they clean her and brush her, and at the tip of their tongue present the first honey of the new life. But the bee, that has come from another world, is bewildered still, trembling and pale; she wears the feeble look of a little old man who might have escaped from his tomb, or perhaps of a traveller strewn with the 


\section{The Young Queens}

powdery dust of the ways that lead unto life. She is perfect, however, from head to foot; she knows at once all that has to be known; and, like the children of the people, who learn, as it were, at their birth, that for them there shall never be time to play or to laugh, she instantly makes her way to the cells that are closed, and proceeds to beat her wings and to dance in cadence, so that she in her turn may quicken her buried sisters; nor does she for one instant pause to decipher the astounding enigma of her destiny, or her race.

$$
\text { [65] }
$$

The most arduous labours will, however, at first be spared her. A week must elapse from the day of her birth before she will quit the hive; she will then perform her first "cleansing flight," and absorb the air into her trachex, which, 


\section{The Life of the Bee}

filling, expand her body, and proclaim her the bride of space. Thereupon she returns to the hive, and waits yet one week more; and then, with her sisters born the same day as herself, she will for the first time set forth to visit the flowers. A special emotion now will lay hold of her; one that French apiarists term the "soleil d'artifice," but which might more rightly perhaps be called the "sun of disquiet." For it is evident that the bees are afraid, that these daughters of the crowd, of secluded darkness, shrink from the vault of blue, from the infinite loneliness of the light; and their joy is halting, and woven of terror. They cross the threshold and pause; they depart, they return, twenty times. They hover aloft in the air, their head persistently turned to the home; they describe great soaring circles that suddenly sink beneath the weight of regret; and their thirteen thou- 


\section{The Young Queens}

sand eyes will question, reflect, and retain the trees and the fountain, the gate and the walls, the neighbouring windows and houses, till at last the aerial course whereon their return shall glide have become as indelibly stamped in their memory as though it were marked in space by two lines of steel.

\section{[66]}

A new mystery confronts us here, which we shall do well to challenge; for though it reply not, its silence still will extend the field of our conscious ignorance, which is the most fertile of all that our activity knows. How do the bees contrive to find their way back to the hive that they cannot possibly see, that is hidden, perhaps, by the trees, that in any event must form an imperceptible point in space? How is it that if taken in a box to a spot two or three miles from their home, they 


\section{The Life of the Bee}

will almost invariably succeed in finding their way back?

Do obstacles offer no barrier to their sight; do they guide themselves by certain indications and landmarks; or do they possess that peculiar, imperfectly understood sense that we ascribe to the swallows and pigeons, for instance, and term the "sense of direction"? The experiments of J. H. Fabre, of Lubbock, and, above all, of Romanes (Nature, 29 Oct. I 886) seem to establish that it is not this strange instinct that guides them. I have, on the other hand, more than once noticed that they appear to pay no attention to the colour or form of the hive. They are attracted rather by the ordinary appearance of the platform on which their home reposes, by the position of the entrance, and of the alighting-board. But this even is merely subsidiary; were the front of the hive to be altered from top 


\section{The Young Queens}

to bottom, during the workers' absence, they would still unhesitatingly direct their course to it from out the far depths of the horizon; and only when confronted by the unrecognisable threshold would they seem for one instant to pause. Such experiments as lie in our power point rather to their guiding themselves by an extraordinarily minute and precise appreciation of landmarks. It is not the hive that they seem to remember, but its position, calculated to the minutest fraction, in its relation to neighbouring objects. And so marvellous is this appreciation, so mathematically certain, so profoundly inscribed in their memory, that if, after five months' hibernation in some obscure cellar, the hive, when replaced on the platform, should be set a little to right or to left of its former position, all the workers, on their return from the earliest flowers, will infallibly steer their direct and unwavering 


\section{The Life of the Bee}

course to the precise spot that it filled the previous year; and only after some hesitation and groping will they discover the door which stands not now where it once had stood. It is as though space had preciously preserved, the whole winter through, the indelible track of their flight: as though the print of their tiny, laborious footsteps, still lay graven in the sky.

If the hive be displaced, therefore, many bees will lose their way; except in the case of their having been carried far from their former home, and finding the country completely transformed that they had grown to know perfectly within a radius of. two or three miles; for then, if care be taken to warn them, by means of a little gangway connecting with the alighting-board, at the entrance to the hive, that some change has occurred, they will at once proceed to 


\section{The Young Queens}

seek new bearings and create fresh landmarks.

$$
\text { [67] }
$$

And now let us return to the city that is being repeopled, where myriad cradles are incessantly opening, and the solid walls even appear to be moving. But this city still lacks a queen. Seven or eight curious structures arise from the centre of one of the combs, and remind us, scattered as they are over the surface of the ordinary cells, of the circles and protuberances that appear so strange on the photographs of the moon. They are a species of capsule, contrived of wrinkled wax or of inclined glands, hermetically sealed, which fills the place of three or four workers' cells. As a rule, they are grouped around the same point ; and a numerous guard keep watch, with singular vigilance and restlessness, over this region that seems instinct with 


\section{The Life of the Bee}

an indescribable prestige. It is here that the mothers are formed. In each one of these capsules, before the swarm departs, an egg will be placed by the mother, or more probably - though as to this we have no certain knowledge - by one of the workers; an egg that she will have taken from some neighbouring cell, and that is absolutely identical with those from which workers are hatched.

From this egg, after three days, a small larva will issue, and receive a special and very abundant nourishment; and henceforth we are able to follow, step by step, the movements of one of those magnificently vulgar methods of nature on which, were we dealing with men, we should bestow the august name of fatality. The little larva, thanks to this regimen, assumes an exceptional development; and in its ideas, no less than in its body, there ensues so considerable a change that the 


\section{The Young Queens}

bee to which it will give birth might almost belong to an entirely different race of insects.

Four or five years will be the period of her life, instead of the six or seven weeks of the ordinary worker. Her abdomen will be twice as long, her colour more golden, and clearer; her sting will be curved, and her eyes have seven or eight thousand facets instead of twelve or thirteen thousand. Her brain will be smaller, but she will possess enormous ovaries, and a special organ besides, the spermatheca, that will render her almost an hermaphrodite. None of the instincts will be hers that belong to a life of toil ; she will have no brushes, no pockets wherein to secrete the wax, no baskets to gather the pollen. The habits, the passions, that we regard as inherent in the bee, will all be lacking in her. She will not crave for air, or the light of the sun; 


\section{The Life of the Bee}

she will die without even once having tasted a flower. Her existence will pass in the shadow, in the midst of a restless throng; her sole occupation the indefatigable search for cradles that she must fill. On the other hand she alone will know the disquiet of love. Not even twice, it may be, in her life shall she look on the light - for the departure of the swarm is by no means inevitable; on one occasion only, perhaps, will she make use of her wings, but then it will be to fly to her lover. It is strange to see so many things - organs, ideas, desires, habits, an entire destiny - depending, not on a germ, which were the ordinary miracle of the plant, the animal, and man, but on a curious inert substance: a drop of honey. ${ }^{1}$

1 It is generally admitted to-day that workers and queens, after the hatching of the egg, receive the same nourishment, - a kind of milk, very rich in nitrogen, 


\section{The Young Queens}

\section{[68 ]}

About a week has passed since the departure of the old queen. The royal nymphs asleep in the capsules are not all of the same age, for it is to the interest of the bees that the births should be nicely gradationed, and take place at regular intervals, in accordance with their possible desire for a second swarm, a third, or even a fourth. The workers have for some hours now been actively thinning the walls of the ripest cell, while the young queen, from within, has been simultaneously gnawing the rounded lid of her prison. And at last her head appears; she thrusts herself forward;

that a special gland in the nurses' head secretes. But after a few days the worker larva are weaned, and put on a coarser diet of honey and pollen; whereas the future queen, until she be fully developet, is copiously fed on the precious milk known as "royal jelly." 


\section{The Life of the Bee}

and, with the help of the guardians who hasten eagerly to her, who brush her, caress her, and clean her, she extricates herself altogether and takes her first steps on the comb. At the moment of birth she too, like the workers, is trembling and pale, but after ten minutes or so her legs become stronger, and a strange restlessness seizes her; she feels that she is not alone, that her kingdom has yet to be conquered, that close by pretenders are hiding; and she eagerly paces the waxen walls in search of her rivals. But there intervene here the mysterious decir sions and wisdom of instinct, of the spirit of the hive, or of the assembly of workers. The most surprising feature of all, as we watch these things happening before us in a hive of glass, is the entire absence of hesitation, of the slightest division of opinion. There is not a trace of discussion or discord. The atmosphere 


\section{The Young Queens}

of the city is one of absolute unanimity, preordained, which reigns over all; and every one of the bees would appear to know in advance the thought of her sisters. And yet this moment is the gravest, the most vital, in their entire history. They have to choose between three or four courses whose results, in the distant future, will be totally different; which, too, the slightest accident may render disastrous. They have to reconcile the multiplication of species which is their passion, or innate duty with the preservation of the hive and its people. They will err at times; they will successively send forth three or four swarms, thereby completely denuding the mother-city; and these swarms, too feeble to organise, will succumb, it may be, at the approach of winter, caught unawares by this climate of ours, which is different far from their original climate, that 


\section{The Life of the Bee}

the bees, notwithstanding all, have never forgotten. In such cases they suffer from what is known as "swarming fever;" a condition wherein life, as in ordinary fever, reacting too ardently on itself, passes its aim, completes the circle, and discovers only death.

\section{[69]}

Of all the decisions before them there is none that would seem imperative; nor can man, if content to play the part of spectator only, foretell in the slightest degree which one the bees will adopt. But that the most careful deliberation governs their choice is proved by the fact that we are able to influence, or even determine it, by for instance reducing or enlarging the space we accord them; or by removing combs full of honey, and setting up, in their stead, empty combs which are well supplied with workers' cells. 


\section{The Young Queens}

The question they have to consider is not whether a second or third swarm shall be immediately launched, - for in arriving at such a decision they would merely be blindly and thoughtlessly yielding to the caprice or temptation of a favourable moment, - but the instantaneous, unanimous adoption of measures that shall enable them to issue a second swarm or "cast" three or four days after the birth of the first queen, and a third swarm three days after the departure of the second, with this first, queen at their head. It must be admitted, therefore, that we discover here a perfectly reasoned system, and a mature combination of plans extending over a period considerable indeed when compared with the brevity of the bee's existence. 


\section{The Life of the Bee}

$$
\text { [70], }
$$

These measures concern the care of the youthful queens who still lie immured in their waxen prisons. Let us assume that the "spirit of the hive" has pronounced against the despatch of a second swarm. Two courses still remain open. The bees may permit the first-born of the royal virgins, the one whose birth we have witnessed, to destroy her sister-enemies; or they may elect to wait till she have performed the perilous ceremony known as the "nuptial flight," whereon the nation's future depends. The immediate massacre will be authorised often, and often denied; but in the latter case it is of course not easy for us to pronounce whether the bees' decision be due to a desire for a second swarm, or to their recognition of the dangers attending the nuptial flight; for it will happen at times that, on 


\section{The Young Queens}

account of the weather unexpectedly becoming less favourable, or for some other reason we cannot divine, they will suddenly change their mind, renounce the cast that they had decreed, and destroy the royal progeny they had so carefully preserved. But at present we will suppose that they have determined to dispense with a second swarm, and that they accept the risks of the nuptial flight. - Our young queen hastens towards the large cradles, urged on by her great desire, and the guard make way before her. Listening only to her furious jealousy, she will fling herself on to the first cell she comes across, madly strip off the wax with her teeth and claws, tear away the cocoon that carpets the cell, and divest the sleeping princess of every covering. If her rival should be already recognisable, the queen will turn so that her sting may enter the capsule, and will frantically stab it with 


\section{The Life of the Bee}

her venomous weapon until the victim perish. She then becomes calmer, appeased by the death that puts a term to the hatred of every creature; she withdraws her sting, hurries to the adjoining cell, attacks it and opens it, passing it by should she find in it only an imperfect larva or nymph; nor does she pause till, at last, exhausted and breathless, her claws and teeth glide harmless over the waxen walls.

The bees that surround her have calmly. watched her fury, have stood by, inactive, moving only to leave her path clear; but no sooner has a cell been pierced and laid waste than they eagerly flock to it, drag out the corpse of the ravished nymph, or the still living larva, and thrust it forth from the hive, thereupon gorging themselves with the precious royal jelly that adheres to the sides of the cell. And finally, when the queen 


\section{The Young Queens}

has become too weak to persist in her passion, they will themselves complete the massacre of the innocents ; and the sovereign race, and their dwellings, will all disappear.

This is the terrible hour of the hive; the only occasion, with that of the more justifiable execution of the drones, when the workers suffer discord and death to be busy amongst them; and here, as often in nature, it is the favoured of love who attract to themselves the most extraordinary shafts of violent death.

It will happen at times that two queens will be hatched simultaneously, the occurrence being rare, however, for the bees take special care to prevent it. But whenever this does take place, the deadly combat will begin the moment they emerge from their cradles; and of this combat Huber was the first to remark an extraordinary feature. Each time, it would seem 


\section{The Life of the Bee}

that the queens, in their passes, present their chitrinous cuirasses to each other in such a fashion that the drawing of the sting would prove mutually fatal; one might almost believe that, even as a god or goddess was wont to interpose in the combats of the Iliad, so a god or a goddess, the divinity of the race, perhaps, interposes here; and the two warriors, stricken with simultaneous terror, divide and $\mathrm{fly}$, to meet shortly after and separate again should the double disaster once more menace the future of their people; till at last one of them shall succeed in surprising her clumsier or less wary rival, and in killing her without risk to herself. For the law of the race has called for one sacrifice only.

$$
\text { [7I] }
$$

The cradles having thus been destroyed and the rivals all slain, the young queen is 256 


\section{The Young Queens}

accepted by her people; but she will not truly reign over them, or be treated as was her mother before her, until the nuptial flight be accomplished; for until she be impregnated the bees will hold her but lightly, and render most passing homage. Her history, however, will rarely be as uneventful as this, for the bees will not often rehounce their desire for a second swarm.

In that case, as before, quick with the same desires, the queen will approach the royal cells; but instead of meeting with docile servants who second her efforts, she will find her, path blocked by a numerous and hostile guard. In her fury, and urged on by her fixed idea, she will endeavour to force her way through, or to outflank them; but everywhere sentinels are posted to protect the sleeping princesses. She persists, she returns to the charge, to be repulsed with ever increasing severity, to be somewhat roughly handled 


\section{The Life of the Bee}

even, until at last she begins vaguely to understand that these little inflexible workers stand for a law before which that law must bend whereby she is inspired.

And at last she goes, and wanders from comb to comb, her unsatisfied wrath finding vent in a war-song, or angry complaint, that every bee-keeper knows; resembling somewhat the note of a distant trumpet of silver; so intense, in its passionate feebleness, as to be clearly audible, in the evening especially, two or three yards from the double walls of the most carefully enclosed hive.

Upon the workers this royal cry has a magical effect. It terrifies them, it induces a kind of respectful stupor; and when the queen sends it forth, as she halts in front of the cells whose approach is denied her, the guardians who have but this moment been hustling her, pushing her back, will at once desist, and wait, 


\section{The Young Queens}

with bent head, till the cry shall have ceased to resound. Indeed, some believe that it is thanks to the prestige of this cry, which the Sphinx Atropos imitates, that the latter is able to enter the hive, and gorge itself with honey, without the least molestation on the part of the bees.

For two or three days, sometimes even for five, this indignant lament will be heard, this challenge that the queen addresses to her well protected rivals. And as these in their turn develop, in their turn grow anxious to see the light, they too set to work to gnaw the lids of their cells. A mighty disorder would now appear to threaten the republic. But the genius of the hive, at the time that it formed its decision, was able to foretell every consequence that might ensue; and the guardians have had their instructions: they know exactly what must be done, hour by hour, to meet the attacks of a foiled in- 


\section{The Life of the Bee}

stinct, and conduct two opposite forces to a successful issue. They are fully aware that if the young queens should escape who now clamour for birth, they would fall into the hands of their elder sister, by this time irresistible, who would destroy them one by one. The workers, therefore, will pile on fresh layers of wax in proportion as the prisoner reduces, from within, the walls of her tower; and the impatient princess will ardently persist in her labour, little suspecting that she has to deal with an enchanted obstacle, that rises ever afresh from its ruin. She hears the war-cry of her rival; and already aware of her royal duty and destiny, although she has not yet looked upon life, nor knows what a hive may be, she answers the challenge from within the depths of her prison. But her cry is different; it is stifled and hollow, for it has to traverse the walls of a tomb; and, when night is falling, and 260 


\section{The Young Queens}

noises are hushed, and high over all there reigns the silence of the stars, the apiarist who nears these marvellous cities and stands, questioning, at their entrance, recognises and understands the dialogue that is passing between the wandering queen and the virgins in prison.

$$
\text { [72] }
$$

To the young princesses, however, this prolonged reclusion is of material benefit; for when they at last are freed they have grown mature and vigorous, and are able to fly. But during this period of waiting the strength of the first queen has also increased, and is sufficient now to enable her to face the perils of the voyage. The time has arrived, therefore, for the departure of the second swarm, or "cast," with the first-born of the queens at its head. No sooner has she gone than the workers left in the hive will set one of the prisoners 


\section{The Life of the Bee}

free; and she will evince the same murderous desires, send forth the same cries of anger, until, at last, after three or four days, she will leave the hive in her turn, at the head of the tertiary swarm; and so in succession, in the case of "swarming fever," till the mother-city shall be completely exhausted.

Swammerdam cites a hive that, through its swarms and the swarms of its swarms, was able in a single season to found no less than thirty colonies.

Such extraordinary multiplication is above all noticeable after disastrous winters; and one might almost believe that the bees, forever in touch with the secret desires of nature, are conscious of the dangers that menace their race. But at ordinary times this fever will rarely occur in a strong and well-governed hive. There are many that swarm only once; and some, indeed, not at all. 


\section{The Young Queens}

After the second swarm the bees, as a rule, will renounce further division, owing either to their having observed the excessive feebleness of their own stock, or to the prudence urged upon them by threatening skies. In that case they will allow the third queen to slaughter the captives; ordinary life will at once be resumed, and pursued with the more ardour for the reason that the workers are all very young, that the hive is depopulated and impoverished, and that there are great voids to fill before the arrival of winter.

$$
\text { [73] }
$$

The departure of the second and third swarms resembles that of the first, and the conditions are identical, with the exception that the bees are fewer in number, less circumspect, and lacking in scouts; and also that the young and virgin queen, being unencumbered and ardent, will $\mathrm{fly}$ 


\section{The Life of the Bee}

much further, and in the first stage lead the swarm to a considerable distance from the hive. The conduct of these second and third migrations will be far more rash, and their future more problematical. The queen at their head, the representative of the future, has not yet been impregnated. Their entire destiny depends on the ensuing nuptial flight. A passing bird, a few drops of rain, a mistake, a cold wind any one of these may give rise to irremediable disaster. Of this the bees are so well aware that when the young queen sallies forth in quest of her lover, they often will abandon the labours they have begun, will forsake the home of a day that already is dear to them, and accompany her in a body, dreading to let het pass out of their sight, eager, as they form closely around her, and shelter her beneath their myriad devoted wings, to lose themselves with her, should love cause 


\section{The Young Queens}

her to stray so far from the hive that the as yet unfamiliar road of return shall grow blurred and hesitating in every memory.

\section{[74]}

But so potent is the law of the future that none of these uncertainties, these perils of death, will cause a single bee to waver. The enthusiasm displayed by the second and third swarms is not less than that of the first. No sooner has the mother-city pronounced its decision than a battalion of workers will flock around each dangerous young queen, eager to follow her fortunes, to accompany her on the voyage where there is so much to lose, and so little to gain beyond the desire of a satisfied instinct. Whence do they derive the energy we ourselves never possess, whereby they break with the past as though with an enemy? Who is it selects from the 265 


\section{The Life of the Bee}

crowd those who shall go forth, and declares who shall remain? No special class divides those who stay from those who wander abroad; it will be the younger here and the elder there; around each queen who shall never return veteran foragers jostle tiny workers, who for the first time shall face the dizziness of the blue. Nor is the proportionate strength of a swarm controlled by chance or accident, by the momentary dejection or transport of an instinct, thought, or feeling. I have more than once tried to establish a relation between the number of bees composing a swarm and the number of those that remain; and although the difficulties of this calculation are such as to preclude anything approaching mathematical precision, I have at least been able to gather that this relation - if we take into account the brood-cells, or in other words the forth- 


\section{The Young Queens}

coming births - is sufficiently constant to point to an actual and mysterious reckoning on the part of the genius of the hive.

\section{[75 ]}

We will not follow these swarms on their numerous, and often most complicated, adventures. Two swarms, at times, will join forces; at others, two or three of the imprisoned queens will profit by the confusion attending the moment of departure to elude the watchfulness of their guardians and join the groups that are forming. Occasionally, too, one of the young queens, finding herself surrounded by males, will cause herself to be impregnated in the swarming flight, and will then drag all her people to an extraordinary height and distance. In the practice of apiculture these secondary and tertiary swarms are always returned 


\section{The Life of the Bee}

to the mother-hive. The queens will meet on the comb; the workers will gather around and watch their combat; and, when the stronger has overcome the weaker they will then, in their ardour for work and hatred of disorder, expel the corpses, close the door on the violence of the future, forget the past, return to their cells, and resume their peaceful path to the flowers that await them.

$$
\text { [ } 76 \text { ] }
$$

We will now, in order to simplify matters, return to the queen whom the bees have permitted to slaughter her sisters, and resume the account of her adventures. As I have already stated, this massacre will be often prevented, and often sanctioned, at times even when the bees apparently do not intend to issue a second swarm; for we notice the same diversity of political spirit in the differ268 


\section{The Young Queens}

ent hives of an apiary as in the different human nations of a continent. But it is clear that the bees will act imprudently in giving their consent; for if the queen should die, or stray in the nuptial flight, it will be impossible to fill her place, the workers' larvæ having passed the age when they are susceptible of royal transformation. Let us assume, however, that the imprudence has been committed; and behold our, first-born, therefore, unique sovereign, and recognised as such in the spirit of her people. But she is still a virgin. To become as was the mother before her, it is essential that she should meet the male within the first twenty days of her life. Should the event for some reason be delayed beyond this period, her virginity becomes irrevocable. And yet we have seen that she is not sterile, virgin though she be. There confronts us here the great mystery - or 269 


\section{The Life of the Bee}

prècaution - of Nature, that is known as parthenogenesis, and is common to a certain number of insects, such as the aphides, the lepidoptera of the Psyche genus, the hymenoptera of the Cynipede family, etc. The virgin queen is able to lay; but from all the eggs that she will deposit in the cells, be these large or small, there will issue males alone; and as these never work, as they live at the expense of the females, as they never go foraging except on their own account, and are generally incapable of providing for their subsistence, the result will be, at the end of some weeks, that the last exhausted worker will perish, and the colony be ruined and totally annihilated. The queen, we have said, will produce thousands of drones; and each of these will possess millions of the spermatozoa whereof it is impossible that a single one can have penetrated into the organism of 


\section{The Young Queens}

the mother. That may not be more astounding, perhaps, than a thousand other and analogous phenomena; and, indeed, when we consider these problems, and more especially those of generation, the marvellous and the unexpected confront us so constantly - occurring far more frequently, and above all in far less human fashion, than in the most miraculous fairy stories - that after a time astonishment becomes so habitual with us that we almost cease to wonder. The fact, however, is sufficiently curious to be worthy of notice. But, on the other hand, how shall we explain to ourselves the aim that nature can have in thus favouring the valueless drones at the cost of the workers who are so essential? Is she afraid lest the females might perhaps be induced by their intellect unduly to limit the number of their parasites, which, destructive though they be, are still necessary for the preser- 


\section{The Life of the Bee}

vation of the race? Or is it merely an exaggerated reaction against the misfortune of the unfruitful queen? Can we have here one of those blind and extreme precautions which, ignoring the cause of the evil, overstep the remedy; and, in the endeavour to prevent an unfortunate accident, bring about a catastrophe? In reality - though we must not forget that the natural, primitive reality is different. from that of the present, for in the original forest the colonies might well be far more scattered than they are to-day in reality the queen's unfruitfulness will rarely be due to the want of males, for these are very numerous always, and will flock from afar; but rather to the rain, or the cold, that will have kept her too long in the hive, and more frequently still to the imperfect state of her wings, whereby she will be prevented from describing the high flight in the air that the organ of the male 


\section{The Young Queens}

demands. Nature, however, heedless of these more intrinsic causes, is so deeply concerned with the multiplication of males, that we sometimes find, in motherless hives, two or three workers possessed of so great a desire to preserve the race that, their atrophied ovaries notwithstanding, they will still endeavour to lay; and, their organs expanding somewhat beneath the empire of this exasperated sentiment, they will succeed in depositing a few eggs in the cells; but from these eggs, as from those of the virgin mother, there will issue only males.

\section{[77]}

Here we behold the active intervention of a superior though perhaps imprudent will, which offers irresistible obstruction to the intelligent will of a life. In the insect world such interventions are comparatively frequent, and much can be 18 


\section{The Life of the Bee}

gained from their study; for this world being more densely peopled and more complex than others, certain special desires of nature are often more palpably revealed to us there; and she may even at times be detected in the midst of experiments we might almost be warranted in regarding as incomplete. She has one great and general desire, for instance, that she displays on all sides; the amelioration of each species through the triumph of the stronger. This struggle, as a rule, is most carefully organised. The hecatomb of the weak is enormous, but that matters little so long as the victors' reward be effectual and certain. But there are cases when one might almost imagine that nature had not had time enough to disentangle her combinations; cases where reward is impossible, and the fate of the victor no less disastrous than that of the vanquished. And of such, selecting an 


\section{The Young Queens}

instance that will not take us too far from our bees, I know of no instance more striking than that of the triongulins of the Sitaris colletes. And it will be seen that, in many details, this story is less foreign to the history of man than might perhaps be imagined.

These triongulins are the primary larvæ of a parasite proper to a wild, obtusetongued, solitary bee, the Colletes, which builds its nest in subterranean galleries. It is their habit to lie in wait for the bee at the approach to these galleries; and then, to the number of three, four, five, or often of more, they will leap on her back, and bury themselves in her hair. Were the struggle of the weak against the strong to take place at this moment there would be no more to be said, and all would pass in accordance with universal law. But, for a reason we know not, their instinct requires, and nature has consequently 


\section{The Life of the Bee}

ordained, that they should hold themselves tranquil so long as they remain on the back of the bee. They patiently bide their time while she visits the flowers, and constructs and provisions her cells. But no sooner has an egg been laid than they all spring upon it ; and the innocent colletes carefully seals down her cell, which she has duly supplied with food, never suspecting that she has at the same time ensured the death of her offspring.

The cell has scarcely been closed when the triongulins grouped round the egg engage in the inevitable and salutary combat of natural selection. The stronger, more agile, will seize its adversary beneath the cuirass, and, raising it aloft, will maintain it for hours in its mandibles until the victim expire. But, while this fight is in progress, another of the triongulins, that had either no rival to meet, or already has conquered, takes possession of the 


\section{The Young Queens}

egg and bursts it open. The ultimate victor has therefore this fresh enemy to subdue; but the conquest is easy, for the triongulin, deep in the satisfaction of its pre-natal hunger, clings obstinately to the egg, and does not even attempt to defend itself. It is quickly despatched; and the other is at last alone, and possessor of the precious egg it has won so well. It eagerly plunges its head into the opening its predecessor had made; and begins the lengthy repast that shall transform it into a perfect insect. But nature, that has decreed this ordeal of battle, has, on the other hand, established the prize of victory with such miserly precision that nothing short of an entire egg will suffice for the nourishment of a single triongulin. So that, as we are informed by M. Mayet, to whom we owe the account of these disconcerting adventures, there is lacking to our conqueror the food its last victim con- 


\section{The Life of the Bee}

sumed before death; and incapable therefore of achieving the first stage of its transformation, it dies in its turn, adhering to the skin of the egg, or adding itself, in the sugary liquid, to the number of the drowned.

$$
\text { [78] }
$$

This case, though rarely to be followed so closely, is not unique in natural history. We have here, laid bare before us, the struggle between the conscious will of the triongulin, that seeks to live, and the obscure and general will of nature, that not only desires that the triongulin should live, but is anxious even that its life should be improved, and fortified, to a degree beyond that to which its own will impels it. But, through some strange inadvertence, the amelioration nature imposes suppresses the life of even the fittest, and the Sitaris Colletes would have long since dis- 


\section{The Young Queens}

appeared had not chance, acting in opposition to the desires of nature, permitted isolated individuals to escape from the excellent and far-seeing law that ordains on all sides the triumph of the stronger.

Can this mighty power err, then, that seems unconscious to us, but necessarily wise, seeing that the life she organises and maintains is forever proving her to be right? Can feebleness at times overcome that supreme reason, which we are apt to invoke when we have attained the limits of our own? And if that be so, by whom shall this feebleness be set right?

But let us return to that special form of her resistless intervention that we find in parthenogenesis. And we shall do well to remember that, remote as the world may seem in which these problema confront us, they do indeed yet concer? ourselves very nearly. Who would dare to affirm that no interventions take place 


\section{The Life of the Bee}

in the sphere of man - interventions that may be more hidden, but not the less fraught with danger? And in the case before us, which is right, in the end, - the insect, or nature? What would happen if the bees, more docile perhaps, or endowed with a higher intelligence, were too clearly to understand the desires of nature, and to follow them to the extreme; to multiply males to infinity, seeing that nature is imperiously calling for males? Would they not risk the destruction of their species? Are we to believe that there are intentions in nature that it is dangerous to understand too clearly, fatal to follow with too much ardour; and that it is one of her desires that we should not divine, and follow, all her desires? Is it not possible that herein there may lie one of the perils of the human race? We too are aware of unconscious forces within us, that would appear to demand the reverse 280 


\section{The Young Queens}

of what our intellect urges. And this intellect of ours, that, as a rule, its own boundary reached, knows not whither to go - can it be well that it should join itself to these forces, and add to them its unexpected weight?

\section{[79]}

Have we the right to conclude, from the dangers of parthenogenesis, that nature is not always able to proportion the means to the end; and that what she intends to preserve is preserved at times by means of precautions she has to contrive against her own precautions, and often through foreign circumstances she has not herself foreseen? But is there anything she does foresee; anything she does intend to preserve? Nature, some may say, is a word wherewith we clothe the unknowable; and few things authorise our crediting it with intelligence, or with aim. That is true. 


\section{The Life of the Bee}

We touch here the hermetically sealed vases that furnish our conception of the universe. Reluctant, over and over again, to label these with the inscription "UNKNOWN," that disheartens us and compels us to silence, we engrave upon them, in the degree of their size and grandeur, the words "Nature, life, death, infinite, selection, spirit of the race," and many others, even as those who went before us affixed the words "God, Providence, destiny, reward," etc. Let it be so, if one will, and no more. But, though the contents of the vases remain obscure, there is gain at least in the fact that the inscriptions to-day convey less menace to us, that we are able therefore to approach them and touch them, and lay our ears close to them and listen, with wholesome curiosity.

But whatever the name we attach to these vases, it is certain that one of them, 


\section{The Young Queens}

at least, and the greatest - that which bears on its flank the name "Nature" encloses a very real force, the most real of all, and one that is able to preserve an enormous and marvellous quantity and quality of life on our globe, by means so skilful that they surpass all that the genius of man could contrive. Could this quantity and quality be maintained by other means? Is it we who deceive ourselves when we imagine that we see precautions where perhaps there is truly no more than a fortunate chance, that has survived a million unfortunate chances?

\section{[80]}

That may be; but these fortunate chances teach us a lesson in admiration as valuable as those we might learn in regions superior to chance. If we let our gaze travel beyond the creatures that are possessed of a glimmer of intellect and 


\section{The Life of the Bee}

consciousness, beyond the protozoa even, which are the first nebulous representatives of the dawning animal kingdom, we find, as has been abundantly proved by the experiments of Mr. H. J. Carter, the celebrated microscopist, that the very lowest embryos, such as the myxomycetes, manifest a will and desires and preferences; and that infusoria, which apparently have no organism whatever, give evidence of a certain cunning. The Amœbæ, for instance, will patiently lie in wait for the new-born Acinetes, as they leave the maternal ovary; being aware that these must as yet be lacking their poisonous tentacles. Now, the Amœbæ have neither a nervous system nor distinguishable organs of any kind. Or if we turn to the plants, which, being motionless, would seem exposed to every fatality, - without pausing to consider carnivorous speeies like the Drusera, which really act as animals, - we are struck 


\section{The Young Queens}

by the genius that some of our humblest flowers display in contriving that the visit of the bee shall infallibly procure them the crossed fertilisation they need. See the marvellous fashion in which the Orchis Moris, our humble country orchid, combines the play of its rostellum and retinacula; observe the mathematical and automatic inclination and adhesion of its pollinia ; as also the unerring double seesaw of the anthers of the wild sage, which touch the body of the visiting insect at a particular spot in order that the insect may, in its turn, touch the stigma of the neighbouring flower at another particular spot; watch, too, in the case of the Pedicularis Sylvatica, the successive, calculated movements of its stigma; and indeed the entrance of the bee into any one of these three flowers sets every organ vibrating, just as the skilful marksman who hits the black spot on the target will cause all the 285 


\section{The Life of the Bee}

figures to move in the elaborate mechanisms we see in our village fairs.

We might go lower still, and show, as Ruskin has shown in his "Ethics of the Dust," the character, habits; and artifices of crystals; their quarrels, and mode of procedure, when a foreign body attempts to oppose their plans, which are more ancient by far than our imagination can conceive; the manner in which they admit or repel an enemy, the possible victory of the weaker over the stronger, as, for instance, when the all-powerful quartz submits to the humble and wily epidote, and allows this last to conquer it; the struggle, terrible sometimes and sometimes magnificent, between the rock-crystal and iron; the regular, immaculate expansion and uncompromising purity of one hyaline block, which rejects whatever is foul, and the sickly growth, the evident immorality, of its brother, which admits 


\section{The Young Queens}

corruption, and writhes miserably in the void; as we might quote also the strange phenomena of crystalline cicatrisation and reintegration mentioned by Claude Bernard, etc. But the mystery here becomes too foreign to us. Let us keep to our flowers, which are the last expression of a life that has yet some kinship with our own. We are not dealing now with animals or insects, to which we attribute a special, intelligent will, thanks to which they survive. We believe, rightly or wrongly, that the flowers possess no such will; at least we cannot discover in them the slightest trace of the organs wherein will, intellect, and initiative of action, are usually born and reside. It follows, therefore, that all that acts in them in so admirable a fashion must directly proceed from what we elsewhere call nature. We are no longer concerned with the intellect of the individual; here we find the un- 


\section{The Life of the Bee}

conscious, undivided force in the act of ensnaring other forms of itself. Shall we on that account refuse to believe that these snares are pure accidents, occurring in accordance with a routine that is also incidental ? We are not yet entitled to such a deduction. It might be urged that these flowers, had these miraculous combinations not been, would not have survived, but would have had their place filled by others that stood in no need of crossed fertilisation; and the non-existence of the first would have been perceived by none, nor would the life that vibrates on the earth have seemed less incomprehensible to us, less diverse, or less astounding.

And yet it would be difficult not to admit that acts which bear all the appearance of acts of intelligence and prudence produce and support these fortunate chances. Whence do they issue, - from the being 


\section{The Young Queens}

itself, or from the force whence that being draws life? I will not say " it matters but little," for, on the contrary, to know the answer were of supreme importance to us. But, in the meantime, and till we shall learn whether it be the flower that endeavours to maintain and perfect the life that nature has placed within it, or whether it be nature that puts forth an effort to maintain and improve the degree of existence the flower has assumed, or finally whether it be chance that ultimately governs chance, a multitude of semblances invite us to believe that something equal to our loftiest thoughts issues at times from a common source, that we are compelled to admire without knowing where it resides.

There are moments when what seems error to us comes forth from this common source. But, although we know 'very few things, proofs abound that the seeming error was in reality an act of 


\section{The Life of the Bee}

prudence that we at first could not grasp. In the little circle, even, that our eyes embrace we are constantly shown that what we regarded as nature's blunder close by was due to her deeming it well to adjust the presumed inadvertence out yonder. She has placed the three flowers we mentioned under conditions of such difficulty that they are unable to fertilise themselves; she considers it beneficial, therefore, for reasons beyond our powers of perception, that they should cause themselves to be fertilised by their neighbours; and, inasmuch as she enhances the intelligence of her victims, she displays on our right the genius she failed to display on our left. The byways of this genius of hers remain incomprehensible to us, but its level is always the same. It will appear to fall into error assuming that error be possible - thereupon rising again at once in the organ 


\section{The Young Queens}

charged to repair this error. Turn where we may, it towers high over our heads. It is the circular ocean, the tideless water, whereon our boldest and most independent thoughts will never be more than mere abject bubbles. We call it Nature to-day; to-morrow, perhaps, we shall give it another name, softer or more alarming. In the meanwhile it holds simultaneous, impartial sway over life and death; furnishing the two irreconcilable sisters with the magnificent and familiar weapons that adorn and distract its bosom.

$$
\text { [8I] }
$$

Does this force take measures to maintain what may be struggling on its surface, or must we say, arguing in the strangest of circles, that what floats on its surface must guard itself against the genius that has given it life? That question must be left open. We have no 


\section{The Life of the Bee}

means of ascertaining whether it be notwithstanding the efforts of the superior will, or independently of these, or lastly because of these, that a species has been able to survive.

All we can say is that such a species exists, and that, on this point, therefore, nature would seem to be right. But who shall tell us how many others that we have not known have fallen victim to her restless and forgetful intellect? Beyond this, we can recognise only the surprising and occasionally hostile forms that the extraordinary fluid we call life assumes, in utter unconsciousness sometimes, at others with a kind of consciousness : the fluid which animates us equally with all the rest, which produces the very thoughts that judge it, and the feeble voice that attempts to tell its story. 


\section{VI}

\section{THE NUPTIAL FLIGHT}




$$
+
$$




\section{VI}

\section{THE NUPTIAL FLIGHT}

$$
\text { [82] }
$$

W ${ }^{\mathrm{E}}$ will now consider the manner in which the impregnation of the queen-bee comes to pass. Here again nature has taken extraordinary measures to favour the union of males with females of a different stock; a strange law, whereto nothing would seem to compel her; a caprice, or initial inadvertence, perhaps, whose reparation calls for the most marvellous forces her activity knows.

If she had devoted half the genius she lavishes on crossed fertilisation and other arbitrary desires to making life more certain, to alleviating pain, to softening death and warding off horrible accidents, the 295 


\section{The Life of the Bee}

universe would probably have presented an enigma less incomprehensible, less pitiable, than the one we are striving to solve. But our consciousness, and the interest we take in existence, must grapple, not with what might have been, but with what is.

Around the virgin queen, and dwelling with her in the hive, are hundreds of exuberant males, forever drunk on honey; the sole reason for their existence being one act of love. But, notwithstanding the incessant contact of two desires that elsewhere invariably triumph over every obstacle, the union never takes place in the hive, nor has it been possible to bring about the impregnation of a captive queen. 1

1 Professor McLain has recently succeeded in causing a few queens to be artificially impregnated; but this has been the result of a veritable surgical operation, of the most delicate and complicated nature. Moreover, the fertility of the queens was restricted and ephemeral. 


\section{The Nuptial Flight}

While she lives in their midst the lovers about her know not what she is. They seek her in space, in the remote depths of the horizon, never suspecting that they have but this moment quitted her, have shared the same comb with her, have brushed against her, perhaps, in the eagerness of their departure. One might almost believe that those wonderful eyes of theirs, that cover their head as though with a glittering helmet, do not recognise or desire her save when she soars in the blue. Each day, from noon till three, when the sun shines resplendent, this plumed horde sallies forth in search of the bride, who is indeed more royal, more difficult of conquest, than the most inaccessible princess of fairy legend; for twenty or thirty tribes will hasten from all the neighbouring cities, her court thus consisting of more than ten thousand suitors; and from these ten thousand one alone will be chosen for the 


\section{The Life of the Bee}

unique kiss of an instant that shall wed him to death no less than to happiness; while the others will fly helplessly round the intertwined pair, and soon will perish without ever again beholding this prodigious and fatal apparition.

$$
\text { [83] }
$$

I am not exaggerating this wild and amazing prodigality of nature. The bestconducted hives will, as a rule, contain four to five hundred males. Weaker or degenerate ones will often have as many as four or five thousand; for the more a hive inclines to its ruin, the more males will it produce. It may be said that, on an average, an apiary composed of ten colonies will at a given moment send an army of ten thousand males into the air, of whom ten or fifteen at most will have the occasion of performing the one act for which they were born. 


\section{The Nuptial Flight}

In the meanwhile they exhaust the supplies of the city ; each one of the parasites requiring the unceasing labour of five or six workers to maintain it in its abounding and voracious idleness, its activity being indeed solely confined to its jaws. But nature is always magnificent when dealing with the privileges and prerogatives of love. She becomes miserly only when doling out the organs and instruments of labour. She is especially severe on what men have termed virtue, whereas she strews the path of the most uninteresting lovers with innumerable jewels and favours. "Unite and multiply; there is no other law, or aim, than love," would seem to be her constant cry on all sides, while she mutters to herself, perhaps: "and exist afterwards if you can ; that is no concern of mine." Do or desire what else we may, we find, everywhere on our road, this morality 


\section{The Life of the Bee}

that differs so much from our own. And note, too, in these same little creatures, her unjust avarice and insensate waste. From her birth to her death, the austere forager has to travel abroad in search of the myriad flowers that hide in the depths of the thickets. She has to discover the honey and pollen that lurk in the labyrinths of the nectaries and in the most secret recesses of the anthers. And yet her eyes and olfactory organs are like the eyes and organs of the infirm, compared with those of the male. Were the drones almost blind, had they only the most rudimentary sense of smell, they scarcely would suffer. They have nothing to do, no prey to hunt down; their food is brought to them ready prepared, and their existence is spent in the obscurity of the hive, lapping honey from the comb. But they are the agents of love ; and the most enormous, most use- 


\section{The Nuptial Flight}

less gifts are flung with both hands into the abyss of the future. Out of a thousand of them, one only, once in his life, will have to seek, in the depths of the azure, the presence of the royal virgin. Out of a thousand one only will have, for one instant, to follow in space the female who desires not to escape. That suffices. The partial power flings open her treasury, wildly, even deliriously. To every one of these unlikely lovers, of whom nine hundred and ninety-nine will be put to death a few days after the fatal nuptials of the thousandth, she has given thirteen thousand eyes on each side of their head, while the worker has only six thousand. According to Cheshire's calculations, she has provided each of their antennæ with thirty-seven thousand eight hundred olfactory cavities, while the worker has only five thousand in both. There we have an instance of the almost universal dis- 


\section{The Life of the Bee}

proportion that exists between the gifts she rains upon love and her niggardly doles to labour; between the favours she accords to what shall, in an ecstasy, create new life, and the indifference wherewith she regards what will patiently have to maintain itself by toil. Whoever would seek faithfully to depict the character of nature, in accordance with the traits we discover here, would design an extraordinary figure, very foreign to our ideal, which nevertheless can only emanate from her. But too many things are unknown to man for him to essay such a portrait, wherein all would be deep shadow save one or two points of flickering light.

$$
\text { [84] }
$$

Very few, I imagine, have profaned the secret of the queen-bee's wedding, which comes to pass in the infinite, radiant circles of a beautiful sky. But we are 


\section{The Nuptial Flight}

able to witness the hesitating departure of the bride-elect and the murderous return of the bride.

However great her impatience, she will yet choose her day and her hour, and linger in the shadow of the portal till a marvellous morning fling open wide the nuptial spaces in the depths of the great azure vault. She loves the moment when drops of dew still moisten the leaves and the flowers, when the last fragrance of dying dawn still wrestles with burning day, like a maiden caught in the arms of a heavy warrior; when through the silence of approaching noon is heard, once and again, a transparent cry that has lingered from sunrise.

Then she appears on the threshold in the midst of indifferent foragers, if she have left sisters in the hive; or surrounded by a delirious throng of workers, should it be impossible to fill her place. 


\section{The Life of the Bee}

She starts her flight backwards; returns twice or thrice to the alighting-board; and then, having definitely fixed in her mind the exact situation and aspect of the kingdom she has never yet seen from without, she departs like an arrow to the zenith of the blue. She soars to a height, a luminous zone, that other bees attain at no period of their life. Far away, caressing their idleness in the midst of the flowers, the males have beheld the apparition, have breathed the magnetic perfume that spreads from group to group till every apiary near is instinct with it. Immediately crowds collect, and follow her into the sea of gladness, whose limpid boundaries ever recede. She, drunk with her wings, obeying the magnificent law of the race that chooses her lover, and enacts that the strongest alone shall attain her in the solitude of the ether, she rises still; and, for the first time in her life, the blue 


\section{The Nuptial Flight}

morning air rushes into her stigmata, singing its song, like the blood of heaven, in the myriad tubes of the tracheal sacs, nourished on space, that fill the centre of her body. She rises still. A region must be found unhaunted by birds, that else might profane the mystery. She rises still; and already the ill-assorted troop below are dwindling and falling asunder. The feeble, infirm, the aged, unwelcome, ill-fed, who have flown from inactive or impoverished cities, these renounce the pursuit and disappear in the void. Only a small, indefatigable cluster remain, suspended in infinite opal. She summons her wings for one final effort; and now the chosen of incomprehensible forces has reached her, has seized her, and bounding aloft with united impetus, the ascending spiral of their intertwined flight whirls for one second in the hostile madness of love. 


\section{The Life of the Bee}

$$
\text { [85] }
$$

Most creatures have a vague belief that a very precarious hazard, a kind of transparent membrane, divides death from love; and that the profound idea of nature demands that the giver of life should die at the moment of giving. Here this idea, whose memory lingers still over the kisses of man, is realised in its primal simplicity. No sooner has the union been accomplished than the male's abdomen opens, the organ detaches itself, dragging with it the mass of the entrails; the wings relax, and, as though struck by lightning, the emptied body turns and turns on itself and sinks down into the abyss.

The same idea that, before, in parthenogenesis, sacrificed the future of the hive to the unwonted multiplication of males, now sacrifices the male to the future of the hive. 


\section{The Nuptial Flight}

This idea is always astounding; and the further we penetrate into it, the fewer do our certitudes become. Darwin, for instance, to take the man of all men who studied it the most methodically and most passionately, Darwin, though scarcely confessing it to himself, loses confidence at every step, and retreats before the unexpected and the irreconcilable. Would you have before you the nobly humiliating spectacle of human genius battling with infinite power, you have but to follow Darwin's endeavours to unravel the strange, incoherent, inconceivably mysterious laws of the sterility and fecundity of hybrids, or of the variations of specific and generic characters. Scarcely has he formulated a principle when numberless exceptions assail him; and this very principle, soon completely overwhelmed, is glad to find refuge in some corner, and preserve a shred of 307 


\section{The Life of the Bee}

existence there under the title of an exception.

For the fact is that in hybridity, in variability (notably in the simultaneous variations known as correlations of growth), in instinct, in the processes of vital competition, in geologic succession and the geographic distribution of organised beings, in mutual affinities, as indeed in every other direction, the idea of nature reveals itself, in one and the same phenomenon and at the very same time, as circumspect and shiftless, niggard and prodigal, prudent and careless, fickle and stable, agitated and immovable, one and innumerable, magnificent and squalid. There lay open before her the immense and virgin fields of simplicity; she chose to people them with trivial errors, with petty contradictory laws that stray through existence like a flock of blind sheep. It is true that our eye, before which these 308 


\section{The Nuptial Flight}

things happen, can only reflect a reality proportionate to our needs and our stature; nor have we any warrant for believing that nature ever loses sight of her wandering results and causes.

In any event she will rarely permit them to stray too far, or approach illogical or dangerous regions. She disposes of two forces that never can err; and when the phenomenon shall have trespassed beyond certain limits, she will beckon to life or to death - which arrives, re-establishes order, and unconcernedly marks out the path afresh.

\section{[86]}

She eludes us on every side; she repudiates most of our rules and breaks our standards to pieces. On our right she sinks far beneath the level of our thoughts, on our left she towers mountain-high above them. She appears to 


\section{The Life of the Bee}

be constantly blundering, no less in the world of her first experiments than in that of her last, of man. There she invests with her sanction the instincts of the obscure mass, the unconscious injustice of the multitude, the defeat of intelligence and virtue, the uninspired morality which urges on the great wave of the race, though manifestly inferior to the morality that could be conceived or desired by the minds composing the small and the clearer wave that ascends the other. And yet, can such a mind be wrong if it ask itself whether the whole truth - moral truths, therefore, as well as non-moral had not better be sought in this chaos than in itself, where these truths would seem comparatively clear and precise?

The man who feels thus will never attempt to deny the reason or virtue of his ideal, hallowed by so many heroes and sages; but there are times when he 


\section{The Nuptial Flight}

will whisper to himself that this ideal has perhaps been formed at too great a distance from the enormous mass whose diverse beauty it would fain represent. He has, hitherto, legitimately feared that the attempt to adapt his morality to that of nature would risk the destruction of what was her masterpiece. But to-day he understands her a little better; and from some of her replies, which, though still vague, reveal an unexpected breadth, he has been enabled to seize a glimpse of a plan and an intellect vaster than could be conceived by his unaided imagination; wherefore he has grown less afraid, nor feels any longer the same imperious need of the refuge his own special virtue and reason afford him. He concludes that what is so great could surely teach nothing that would tend to lessen itself. $\mathrm{He}$ wonders whether the moment may not have arrived for submitting to a more 


\section{The Life of the Bee}

judicious examination his convictions, his principles, and his dreams.

Once more, he has not the slightest desire to abandon his human ideal. That even which at first diverts him from this ideal teaches him to return to it. It were impossible for nature to give ill advice to a man who declines to include in the great scheme he is endeavouring to grasp, who declines to regard as sufficiently lofty to be definitive, any truth that is not at least as lofty as the truth he himself desires. Nothing shifts its place in his life save only to rise with him; and he knows he is rising when he finds himself drawing near to his ancient image of good. But all things transform themselves more freely in his thoughts; and he can descend with impunity, for he has the presentiment that numbers of successive valleys will lead him to the plateau that he expects. And, while he thus 


\section{The Nuptial Flight}

seeks for conviction, while his researches even conduct him to the very reverse of that which he loves, he directs his conduct by the most humanly beautiful truth, and clings to the one that provisionally seems to be highest. All that may add to beneficent virtue enters his heart at once; all that would tend to lessen it remaining there in suspense, like insoluble salts that change not till the hour for decisive experiment. He may accept an inferior truth, but before he will act in accordance therewith he will wait, if need be for centuries, until he perceive the connection this truth must possess with truths so infinite as to include and surpass all others.

In a word, he divides the moral from the intellectual order, admitting in the former that only which is greater and more beautiful than was there before. And blameworthy as it may be to separate the 


\section{The Life of the Bee}

two orders in cases, only too frequent in life, where we suffer our conduct to be inferior to our thoughts, where, seeing the good, we follow the worse - to see the worse and follow the better, to raise our actions high over our idea, must ever be reasonable and salutary; for human experience renders it daily more clear that the highest thought we can attain will long be inferior still to the mysterious truth we seek. Moreover, should nothing of what goes before be true, a reason more simple and more familiar would counsel him not yet to abandon his human ideal. For the more strength he accords to the laws which would seem to set egoism, injustice, and cruelty as examples for men to follow, the more strength does be at the same time confer on the others that ordain generosity, justice, and pity; and these last laws are found to contain something as profoundly natural as the first, the moment he begins 


\section{The Nuptial Flight}

to equalise, or allot more methodically, the share he attributes to the universe and to himself.

\section{[87]}

Let us return to the tragic nuptials of the queen. Here it is evidently nature's wish, in the interests of crossed fertilisation, that the union of the drone and the queen-bee should be possible only in the open sky. But her desires blend networkfashion, and her most valued laws have to pass through the meshes of other laws, which, in their turn, the moment after, are compelled to pass through the first.

In the sky she has planted so many dangers - cold winds, storm-currents, birds, insects, drops of water, all of which also obey invincible laws - that she must of necessity arrange for this union to be as brief as possible. It is so, thanks to the startlingly sudden death of the male. 


\section{The Life of the Bee}

One embrace suffices; the rest all enacts itself in the very flanks of the bride.

She descends from the azure heights and returns to the hive, trailing behind her, like an oriflamme, the unfolded entrails of her lover. Some writers pretend that the bees manifest great joy at this return so big with promise - Büchner, among others, giving a detailed account of it. I have many a time lain in wait for the queen-bee's return, and I confess that I have never noticed any unusual emotion except in the case of a young queen who had gone forth at the head of a swarm, and represented the unique hope of a newly founded and still empty city. In that instance the workers were all wildly excited, and rushed to meet her. But as a rule they appear to forget her, even though the future of their city will often be no less imperilled. They act with consistent prudence in all things, till the 


\section{The Nuptial Flight}

moment when they authorise the massacre of the rival queens. That point reached, their instinct halts; and there is, as it were, a gap in their foresight. - They appear to be wholly indifferent. They raise their heads; recognise, probably, the murderous tokens of impregnation; but, still mistrustful, manifest none of the gladness our expectation had pictured. Being positive in their ways, and slow at illusion, they probably need further proofs before permitting themselves to rejoice. Why endeavour to render too logical, or too human, the feelings of little creatures so different from ourselves? Neither among the bees nor among any other animals that have a ray of our intellect, do things happen with the precision our books record. Too many circumstances remain unknown to us. Why try to depict the bees as more perfect than they are, by saying that which is not? Those who 


\section{The Life of the Bee}

would deem them more interesting did they resemble ourselves, have not yet truly realised what it is that should awaken the interest of a sincere mind. The aim of the observer is not to surprise, but to comprehend; and to point out the gaps existing in an intellect, and the signs of a cerebral organisation different from our own, is more curious by far than the relating of mere marvels concerning it.

But this indifference is not shared by all; and when the breathless queen has reached the alighting-board, some groups will form and accompany her into the hive; where the sun, hero of every festivity in which the bees take part, is entering with little timid steps, and bathing in azure and shadow the waxen walls and curtains of honey. Nor does the new bride, indeed, show more concern than her people, there being not room for many emotions in her narrow, barbarous, prac- 


\section{The Nuptial Flight}

tical brain. She has but one thought, which is to rid herself as quickly as possible of the embarrassing souvenirs her consort has left her, whereby her movements are hampered. She seats herself on the threshold, and carefully strips off the useless organs, that are borne far away by the workers; for the male has given her all he possessed, and much more than she requires. She retains only, in her spermatheca, the seminal liquid where millions of germs are floating, which, until her last day, will issue one by one, as the eggs pass by, and in the obscurity of her body accomplish the mysterious union of the male and female element, whence the worker-bees are born. Through a curious inversion, it is she who furnishes the male principle, and the drone who provides the female. Two days after the union she lays her first eggs, and her people immediately surround her with the 


\section{The Life of the Bee}

most particular care. From that moment, possessed of a dual sex, having within her an inexhaustible male, she begins her veritable life; she will never again leave the hive, unless to accompany a swarm; and her fecundity will cease only at the approach of death.

\section{[88 ]}

Prodigious nuptials these, the most fairylike that can be conceived, azure and tragic, raised high above life by the impetus of desire; imperishable and terrible, unique and bewildering, solitary and infinite. An admirable ecstasy, wherein death supervening in all that our sphere has of most limpid and loveliest, in virginal, limitless space, stamps the instant of happiness in the sublime transparence of the great sky; purifying in that immaculate light the something of wretchedness that always hovers around love, 


\section{The Nuptial Flight}

rendering the kiss one that can never be forgotten; and, content this time with moderate tithe, proceeding herself, with hands that are almost maternal, to introduce and unite, in one body, for a long and inseparable future, two little fragile lives.

Profound truth has not this poetry, but possesses another that we are less apt to grasp, which, however, we should end, perhaps, by understanding and loving. Nature has not gone out of her way to provide these two "abbreviated atoms," as Pascal would call them, with a resplendent marriage, or an ideal moment of love. Her concern, as we have said, was merely to improve the race by means of crossed fertilisation. To ensure this she has contrived the organ of the male in such a fashion that he can make use of it only in space. A prolonged flight must first expand his two great tracheal sacs; these 


\section{The Life of the Bee}

enormous receptacles being gorged on air will throw back the lower part of the abdomen, and permit the exsertion of the organ. There we have the whole physiological secret - which will seem ordinary enough to some, and almost vulgar to athers - of this dazzling pursuit and these magnificent nuptials.

\section{[89]}

"But must we always, then," the poet will wonder, "rejoice in regions that are loftier than the truth ?"

Yes, in all things, at all times, let us rejoice, not in regions loftier than the truth, for that were impossible, but in regions higher than the little truths that our eye can seize. Should a chance, a recollection, an illusion, a passion, - in a word, should any motive whatever cause an object to reveal itself to us in a more beautiful light than to others, let that 


\section{The Nuptial Flight}

motive be first of all dear to us. It may only be error, perhaps; but this error will not prevent the moment wherein this object appears the most admirable to us from being the moment wherein we are likeliest to perceive its real beauty. The beauty we lend it directs our attention to its veritable beauty and grandeur, which, derived as they are from the relation wherein every object must of necessity stand to general, eternal, forces and laws, might otherwise escape observation. The faculty of admiring which an illusion may have created within us will serve for the truth that must come, be it sooner or later. It is with the words, the feelings, and ardour created by ancient and imaginary beauties, that humanity welcomes today truths which perhaps would have never been born, which might not have been able to find so propitious a home, had these sacrificed illusions not first of all 


\section{The Life of the Bee}

dwelt in, and kindled, the heart and the reason whereinto these truths should descend. Happy the eyes that need no illusion to see that the spectacle is great! It is illusion that teaches the others to look, to admire, and rejoice. And look as high as they will, they never can look too high. Truth rises as they draw nearer; they draw nearer when they admire. And whatever the heights may be whereon they rejoice, this rejoicing can never take place in the void, or above the unknown and eternal truth that rests over all things like beauty in suspense.

$$
\text { [90] }
$$

Does this mean that we should attach ourselves to falsehood, to an unreal and factitious poetry, and find our gladness therein for want of anything better? Or that in the example before us-in itself nothing, but we dwell on it because it 


\section{The Nuptial Flight}

stands for a thousand others, as also for our entire attitude in face of divers orders of truths - that here we should ignore the physiological explanation, and retain and taste only the emotions of this nuptial flight, which is yet, and whatever the cause, one of the most lyrical, most beautiful acts of that suddenly disinterested, irresistible force which all living creatures obey and are wont to call love? That were too childish; nor is it possible, thanks to the excellent habits every loyal mind has today acquired.

The fact being incontestable, we must evidently admit that the exsertion of the organ is rendered possible only by. the expansion of the tracheal vesicles. But if we, content with this fact, did not let our eyes roam beyond it; if we deduced therefrom that every thought that rises too high or wanders too far must be of necessity wrong, and that truth must be 


\section{The Life of the Bee}

looked for only in the material details; if we did not seek, no matter where, in uncertainties often far greater than the one this little explanation has solved, in the strange mystery of crossed fertilisation for instance, or in the perpetuity of the race and life, or in the scheme of nature; if we did not seek in these for something beyond the current explanation, something that should prolong it, and conduct us to the beauty and grandeur that repose in the unknown, I would almost venture to assert that we should pass our existence further away from the truth than those, even, who in this case wilfully shut their eyes to all save the poetic and wholly imaginary interpretation of these marvellous nuptials. They evidently misjudge the form and colour of the truth, but they live in its atmosphere and its influence far more than the others, who complacently believe that 


\section{The Nuptial Flight}

the entire truth lies captive within their two hands. For the first have made ample preparations to receive the truth, have provided most hospitable lodging within them; and even though their eyes may not see it, they are eagerly looking towards the beauty and grandeur where its residence surely must be.

We know nothing of nature's aim, which for us is the truth that dominates every other. But for the very love of this truth, and to preserve in our soul the ardour we need for its search, it behoves us to deem it great. And if we should find one day that we have been on a wrong road, that this aim is incoherent and petty, we shall have discovered its pettiness by means of the very zeal its presumed grandeur had created within us; and this pettiness once established, it will teach us what we have to do. In the meanwhile it cannot be unwise to devote to its 


\section{The Life of the Bee}

search the most strenuous, daring efforts of our heart and our reason. And should the last word of all this be wretched, it will be no little achievement to have laid bare the inanity and the pettiness of the aim of nature.

\section{[91 ]}

"There is no truth for us yet," a great physiologist of our day remarked to me once, as I walked with him in the country; "there is no truth yet, but there are everywhere three very good semblances of truth. Each man makes his own choice, or rather, perhaps, has it thrust upon him ; and this choice, whether it be thrust upon him, or whether, as is often the case, he have made it without due reflection, this choice, to which he clings, will determine the form and the conduct of all that enters within him. The friend whom we meet, the woman 


\section{The Nuptial Flight}

who approaches and smiles, the love that unlocks our heart, the death or sorrow that seals it, the September sky above us, this superb and delightful garden, wherein we see, as in Corneille's 'Psyche,' bowers of greenery resting on gilded statues, and the flocks grazing yonder, with their shepherd asleep, and the last houses of the village, and the sea between the trees, - all these are raised or degraded before they enter within us, are adorned or despoiled, in accordance with the little signal this choice of ours makes to them. We must learn to select from among these semblances of truth. I have spent my own life in eager search for the smaller truths, the physical causes; and now, at the end of my days, I begin to cherish, not what would lead me from these, but what would precede them, and, above all, what would somewhat surpass them."

We had attained the summit of a 


\section{The Life of the Bee}

plateau in the "pays de Caux," in Normandy, which is supple as an English park, but natural and limitless. It is one of the rare spots on the globe where nature reveals herself to us unfailingly wholesome and green. A little further to the north the country is threatened with barrenness, a little further to the south, it is fatigued and scorched by the sun. At the end of a plain that ran down to the edge of the sea, some peasants were erecting a stack of corn. "Look," he said, "seen from here, they are beautiful. They are constructing that simple and yet so important thing, which is above all else the happy and almost unvarying monument of human life taking root a stack of corn. The distance, the air of the evening, weave their joyous cries into a kind of song without words, which replies to the noble song of the leaves as they whisper over our heads. Above 


\section{The Nuptial Flight}

them the sky is magnificent; and one almost might fancy that beneficent spirits, waving palm-trees of fire, had swept all the light towards the stack, to give the workers more time. And the track of the palms still remains in the sky. See the humble church by their side, overlooking and watching them, in the midst of the rounded lime trees and the grass of the homely graveyard, that faces its native ocean. They are fitly erecting their monument of life underneath the monuments of their dead, who made the same gestures and still are with them. Take in the whole picture. There are no special, characteristic features, such as we find in England, Provence, or Holland. It is the presentment, large and ordinary enough to be symbolic, of a natural and happy life. Observe how rhythmic human existence becomes in its useful moments. Look at the man who is 


\section{The Life of the Bee}

leading the horses, at that other who throws up the sheaves on his fork, at the women bending over the corn, and the children at play.... They have not displaced a stone, or removed a spadeful of earth, to add to the beauty of the scenery; nor do they take one step, plant a tree or a flower, that is not necessary. All that we see is merely the involuntary result of the effort that man puts forth to subsist for a moment in nature; and yet those among us whose desire is only to create or imagine spectacles of peace, deep thoughtfulness, or beatitude, have been able to find no scene more perfect than this, which indeed they paint or describe whenever they seek to present us with a picture of beauty or happiness. Here we have the first semblance, whicb some will call the truth." 


\section{The Nuptial Flight}

$$
\text { [ } \left.9^{2}\right]
$$

"Let us draw nearer. Can you distinguish the song that blended so well with the whispering of the leaves? It is made up of abuse and insult; and when laughter bursts forth, it is due to an obscene remark some man or woman has made, to a jest at the expense of the weaker, - of the hunchback unable to lift his load, the cripple they have knocked over, or the idiot whom they make their butt.

"I have studied these people for many years. We are in Normandy ; the soil is rich and easily tilled. Around this stack of corn there is rather more comfort than one would usually associate with a scene of this kind. The result is that most of the men, and many of the women, are alcoholic. Another poison also, which I need not name, corrodes the race. To 


\section{The Life of the Bee}

that, to the alcohol, are due the children whom you see there: the dwarf, the one with the hare-lip, the others who are knock-kneed, scrofulous, imbecile. All of them, men and women, young and old, have the ordinary vices of the peasant. They are brutal, suspicious, grasping, and envious; hypocrites, liars, and slanderers ; inclined to petty, illicit profits, mean inrerpretations, and coarse flattery of the stronger. Necessity brings them together, and compels them to help each other; but the secret wish of every individual is to harm his neighbour as soon as this can be done without danger to himself. The one substantial pleasure of the village is procured by the sorrows of others. Should a great disaster befall one of them, it will long be the subject of secret, delighted comment among the rest. Every man watches his fellow, is jealous of him, detests and despises him. While 


\section{The Nuptial Flight}

they are poor, they hate their masters with a boiling and pent-up hatred because of the harshness and avarice these last display; should they in their turn have servants, they profit by their own experience of servitude to reveal a harshness and avarice greater even than that from which they have suffered. I could give you minutest details of the meanness, deceit, injustice, tyranny, and malice that underlie this picture of ethereal, peaceful toil. Do not imagine that the sight of this marvellous sky, of the sea which spreads out yonder behind the church and presents another, more sensitive sky, flowing over the earth like a great mirror of wisdom and consciousness - do not imagine that either sea or sky is capable of lifting their thoughts or widening their minds. They have never looked, at them. Nothing has power to influence or move them save three or four circumscribed fears, that of 


\section{The Life of the Bee}

hunger, of force, of opinion and law, and the terror of hell when they die. To show what they are, we should have to consider them one by one. See that tall fellow there on the right, who flings up such mighty sheaves. Last summer his friends broke his right arm in some tavern row. I reduced the fracture, which was a bad and compound one. I tended him for a long time, and gave him the wherewithal to live till he should be able to get back to work. $\mathrm{He}$ came to me every day. He profited by this to spread the report in the village that he had discovered me in the arms of my sister-in-law, and that my mother drank. $\mathrm{He}$ is not vicious, he bears me no ill-will; on the contrary, see what a broad, open smile spreads over his face as he sees me. It was not social animosity that induced him to slander me. The peasant values wealth far too much to hate the rich man. But 


\section{The Nuptial Flight}

I fancy my good corn-thrower there could not understand my tending him without any profit to myself. $\mathrm{He}$ was satisfied that there must be some underhand scheme, and he declined to be my dupe. More than one before him, richer or poorer, has acted in similar fashion, if not worse. It did not occur to him that he was lying when he spread those inventions abroad; he merely obeyed a confused command of the morality he saw about him. He yielded unconsciously, against his will, as it were, to the all-powerful desire of the general malevolence. . . . But why complete a picture with which all are familiar who have spent some years in the country? Here we have the second semblance that some will call the real truth. It is the truth of practical life. It undoubtedly is based on the most precise, the only, facts that one can observe and test." 


\section{The Life of the Bee}

\section{[93 ]}

"Let us sit on these sheaves," he continued, "and look again. Let us reject not a single one, of the little facts that build up the reality of which I have spoken. Let us permit them to depart of their own accord into space. They cumber the foreground, and yet we cannot but be aware of the existence behind them of a great and very curious force that sustains the whole. Does it only sustain and not raise? These men whom we see before us are at least no longer the ferocious animals of whom $\mathbf{L a}$ Bruyère speaks, the wretches who talked in a kind of inarticulate voice, and withdrew at night to their dens, where they lived on black bread, water, and roots.

"The race, you will tell me, is neither as strong nor as healthy. That may be; 


\section{The Nuptial Flight}

alcohol and the other scourge are accidents that humanity has to surmount; ordeals, it may be, by which certain of our organs, those of the nerves, for instance, may benefit; for we invariably find that life profits by the ills that it overcomes. Besides, a mere trifle that we may discover to-morrow may render these poisons innocuous. These men have thoughts and feelings that those of whom La Bruyère speaks had not." "I prefer the simple, naked animal to the odious half-animal," I murmured. "You are thinking of the first semblance now," he replied, "the semblance dear to the poet, that we saw before; let us not confuse it with the one we are now considering. These thoughts and feelings are petty, if you will, and vile; but what is petty and vile is still better than that which is not at all. Of these thoughts and feelings they avail themselves only to hurt 


\section{The Life of the Bee}

each other, and to persist in their present mediocrity; but thus does it often happen in nature. The gifts she accords are employed for evil at first, for the rendering worse what she had apparently sought to improve; but, from this evil, a certain good will always result in the end. Besides, I am by no means anxious to prove that there has been progress, which may be a very small thing or a very great thing, according to the place whence we regard it. It is a vast achievement, the surest ideal, perhaps, to render the condition of men a little less servile, a little less painful; but let the mind detach itself for an instant from material results, and the difference between the man who marches in the van of progress and the other who is blindly dragged at its tail ceases to be very considerable. Among these young rustics, whose mind is haunted only by formless ideas, there are many 


\section{The Nuptial Flight}

who have in themselves the possibility of attaining, in a short space of time, the degree of consciousness that we both enjoy. One is often struck by the narrowness of the dividing line between what we regard as the unconsciousness of these people and the consciousness that to us is the highest of all.

"Besides, of what is this consciousness composed, whereof we are so proud? Of far more shadow than light, of far more acquired ignorance than knowledge; of far more things whose comprehension, we are well aware, must ever elude us, than of things that we actually know. And yet in this consciousness lies all our dignity, our most veritable greatness; it is probably the most surprising phenomenon this world contains. It is this which per mits us to raise our head before the unknown principle, and say to it: 'What you are I know not; but there is some- 


\section{The Life of the Bee}

thing within me that already enfolds you. You will destroy me, perhaps, but if your object be not to construct from my ruins. an organism better than mine, you will prove yourself inferior to what I am; and the silence that will follow the death of the race to which I belong will declare to you that you have been judged. And if you are not capable even of caring whether you be justly judged or not, of what value can your secret be? It must be stupid or hideous. Chance has enabled you to produce a creature that you yourself lacked the quality to produce. It is fortunate for him that a contrary chance should have permitted you to suppress him before he had fathomed the depths of your unconsciousness; more fortunate still that he does not survive the infinite series of your awful experiments. He had nothing to do in a world where his intellect corresponded 


\section{The Nuptial Flight}

to no eternal intellect, where his desire for the better could attain no actual good.'

"Once more, for the spectacle to absorb us, there is no need of progress. The enigma suffices; and that enigma is as great, and shines as mysteriously, in the peasants as in ourselves. As we trace life back to its all-powerful principle, it confronts us on every side. To this principle each succeeding century has given a new name. Some of these names were clear and consoling. It was found, however, that consolation and clearness were alike illusory. But whether we call it God, Providence, Nature, chance, life, fatality, spirit, or matter, the mystery remains unaltered; and from the experience of thousands of years we have learned nothing more than to give it a vaster name, one nearer to ourselves, more congruous with our expectation, with the unforeseen. 


\section{The Life of the Bee}

That is the name it bears to-day, wherefore it has never seemed greater. Here we have one of the numberless aspects of the third semblance, which also is truth." 


\section{VII}

\section{THE MASSACRE OF THE MALES}





\section{VII}

\section{THE MASSACRE OF THE MALES}

\section{[94]}

TF skies remain clear, the air warm, and 1 pollen and nectar abound in the flowers, the workers, through a kind of forgetful indulgence, or over-scrupulous prudence perhaps, will for a short time longer endure the importunate, disastrous presence of the males. These comport themselves in the hive as did Penelope's suitors in the house of Ulysses. Indelicate and wasteful, sleek and corpulent, fully content with their idle existence as honorary lovers, they feast and carouse, throng the alleys, obstruct the passages, and hinder the work; jostling and jos- 


\section{The Life of the Bee}

tled, fatuously pompous, swelled with foolish, good-natured contempt; harbouring never a suspicion of the deep and calculating scorn wherewith the workers regard them, of the constantly growing hatred to which they give rise, or of the destiny that awaits them. For their pleasant slumbers they select the snuggest corners of the hive; then, rising carelessly, they flock to the open cells where the honey smells sweetest, and soil with their excrements the combs they frequent., The patient workers, their eyes steadily fixed on the future, will silently set things right. From noon till three, when the purple country trembles in blissful lassitude beneath the invincible gaze of a July or August sun, the drones will appear on the threshold. They have a helmet made of enormous black pearls, two lofty, quivering plumes, a doublet of iridescent, yellowish velvet, an heroic 


\section{The Massacre of the Males}

tuft, and a fourfold mantle, translucent and rigid. They create a prodigious stir, brush the sentry aside, overturn the cleaners, and collide with the foragers as these return laden with their humble spoil. They have the busy air, the extravagant, contemptuous gait, of indispensable gods who should be simultaneously venturing towards some destiny unknown to the vulgar. One by one they sail off into space, irresistible, glorious, and tranquilly make for the nearest flowers, where they sleep till the afternoon freshness awake them. Then, with the same majestic pomp, and still overflowing with magnificent schemes, they return to the hive, go straight to the cells, plunge their head to the neck in the vats of honey, and fill themselves cight as a drum to repair their exhausted strength; whereupon, with heavy steps, they go forth to meet the good, dreamless 


\section{The Life of the Bee}

and careless slumber that shall fold them in its embrace till the time for the next repast.

\section{[95]}

But the patience of the bees is not equal to that of men. One morning the long-expected word of command goes through the hive; and the peaceful workers turn into judges and executioners. Whence this word issues, we know not; it would seem to emanate suddenly from the cold, deliberate indignation of the workers; and no sooner has it been uttered than every heart throbs with it, inspired with the genius of the unanimous republic. One part of the people renounce their foraging duties to devote themselves to the work of justice. The great idle drones, asleep in unconscious groups on the melliferous walls, are rudely torn from their slumbers by an army 


\section{The Massacre of the Males}

of wrathful virgins. They wake, in pious wonder; they cannot believe their eyes; and their astonishment struggles through their sloth as a moonbeam through marshy water. They stare amazedly round them, convinced that they must be victims of some mistake; and the mother-idea of their life being first to assert itself in their dull brain, they take a step towards the vats of honey to seek comfort there. But ended for them are the days of May honey, the wine-flower of lime trees and fragrant ambrosia of thyme and sage, of marjoram and white clover. Where the path once lay open to the kindly, abundant reservoirs, that so invitingly offered their waxen and sugary mouths, there stands now a burning-bush all alive with poisonous, bristling stings. The atmosphere of the city is changed; in lieu of the friendly perfume of honey, the acrid odour 


\section{The Life of the Bee}

of poison prevails; thousands of tiny drops glisten at the end of the stings, and diffuse rancour and hatred. Before the bewildered parasites are able to realise that the happy laws of the city have crumbled, dragging down in most inconceivable fashion their own plentiful destiny, each one is assailed by three or four envoys of justice; and these vigorously proceed to cut off his wings, saw through the petiole that connects the abdomen with the thorax, amputate the feverish antenne, and seek an opening between the rings of his cuirass through which to pass their sword. No defence is attempted by the enormous, but unarmed, creatures; they try to escape, or oppose their mere bulk to the blows that rain down upon them. Forced on to their back, with their relentless enemies clinging doggedly to them, they will use their powerful claws to shift them from side to side; or, turn- 


\section{The Massacre of the Males}

ing on themselves, they will drag the whole group round and round in wild circles, which exhaustion soon brings to an end. And, in a very brief space, their appearance becomes so deplorable that pity, never far from justice in the depths of our heart, quickly returns, and would seek forgiveness, though vainly, of the stern workers who recognise only nature's harsh and profound laws. The wings of the wretched creatures are torn, their antennæ bitten, the segments of their legs wrenched off; and their magnificent eyes, mirrors once of the exuberant flowers, flashing back the blue light and the innocent pride of summer, now, softened by suffering, reflect only the anguish and distress of their end. Some succumb to their wounds, and are at once borne away to distant cemeteries by two or three of their executioners. Others, whose injuries are less, succeed in sheltering themselves 


\section{The Life of the Bee}

in some corner, where they lie, all huddled together, surrounded by an inexorable guard, until they perish of want. Many will reach the door, and escape into space dragging their adversaries with them; but, towards evening, impelled by hunger and cold, they return in crowds to the entrance of the hive to beg for shelter. But there they encounter another pitiless guard. The next morning, before setting forth on their journey, the workers will clear the threshold, strewn with the corpses of the useless giants; and all recollection of the idle race disappear till the following spring.

$$
\text { [96] }
$$

In very many colonies of the apiary this massacre will often take place on the same day. The richest, best-governed hive will give the signal; to be followed, some days after, by the little 
The Massacre of the Males

and less prosperous republics. Only the poorest, weakest colonies - those whose mother is very old and almost sterile will preserve their males till the approach of winter, so as not to abandon the hope of procuring the impregnation of the virgin queen they await, and who may yet be born. Inevitable misery follows; and all the tribe-mother, parasites, workers - collect in a hungry and closely intertwined group, who perish in silence before the first snows arrive, in the obscurity of the hive.

In the wealthy and populous cities work is resumed after the execution of the drones, - although with diminishing zeal, for flowers are becoming scarce. The great festivals, the great dramas, are over. The autumn honey, however, that shall complete the indispensable provisions, is accumulating within the hospitable walls; and the last reservoirs are 


\section{The Life of the Bee}

sealed with the seal of white, incorruptible wax. Building ceases, births diminish, deaths multiply; the nights lengthen, and days grow shorter. Rain and inclement winds, the mists of the morning, the ambushes laid by a hastening twilight, carry off hundreds of workers who never return; and soon, over the whole little people, that are as eager for sunshine as the grasshoppers of Attica, there hangs the cold menace of winter.

Man has already taken his share of the harvest. Every good hive has presented him with eighty or a hundred pounds of honey; the most remarkable will sometimes even give two hundred, which represent an enormous expanse of liquefied light, immense fields of flowers that have been visited daily one or two thousand times. He throws a last glance over the colonies, which are becoming torpid. From the richest he takes their 


\section{The Massacre of the Males}

superfluous wealth to distribute it among those whom misfortune, unmerited always in this laborious world, may have rendered necessitous. He covers the dwellings, half closes the doors, removes the useless frames, and leaves the bees to their long winter sleep. They gather in the centre of the hive, contract themselves, and cling to the combs that contain the faithful urns; whence there shall issue, during days of frost, the transmuted substance of summer. The queen is in the midst of them, surrounded by her guard. The first row of the workers attach themselves to the sealed cells; a second row cover the first, a third the second, and so in succession to the last row of all, which form the envelope. When the bees of this envelope feel the cold stealing over them, they re-enter the mass, and others take their place. The suspended cluster is like a sombre 


\section{The Life of the Bee}

sphere that the walls of the comb divide; it rises imperceptibly and falls, it advances or retires, in proportion as the cells grow empty to which it clings. For, contrary to what is generally believed, the winter life of the bee is not arrested, although it be slackened. By the concerted beating of their wings - little sisters that have survived the flames of the sun - which go quickly or slowly in accordance as the temperature without may vary, they maintain in their sphere an unvarying warmth, equal to that of a day in spring. This secret spring comes from the beautiful honey, itself but a ray of heat transformed, that returns now to its first condition. It circulates in the hive like generous blood. The bees at the full cells present it to their neighbours, who pass it on in their turn. Thus it goes from hand to hand and from mouth to mouth, till it attain the extrem- 


\section{The Massacre of the Males}

ity of the group in whose thousands of hearts one destiny, one thought, is scattered and united. It stands in lieu of the sun and the flowers, till its elder brother, the veritable sun of the real, great spring, peering through the half-open door, glides in his first softened glances, wherein anemones and violets are coming to life again; and gently awakens the workers, showing them that the sky once more is blue in the world, and that the uninterrupted circle that joins death to life has turned and begun afresh. 



\section{VIII}

THE PROGRESS OF THE RACE

$3^{6 r}$ 



\section{VIII}

\section{THE PROGRESS OF THE RACE}

$$
\text { [ } 97 \text { ] }
$$

REFORE closing this book - as we have closed the hive on the torpid silence of winter - I am anxious to meet the objection invariably urged by those to whom we reveal the astounding industry and policy of the bees. Yes, they will say, that is all very wonderful; but then, it has never been otherwise. The bees have for thousands of years dwelt under remarkable laws, but during those thousands of years the laws have not varied. For thousands of years they have constructed their marvellous combs, whereto we can add nothing, wherefrom we can take nothing, - combs that unite 


\section{The Life of the Bee}

in equal perfection the science of the chemist, the geometrician, the architect, and the engineer; but on the sarcophagi, on Egyptian stones and papyri, we find drawings of combs that are identical in every particular. Name a single fact that will show the least progress, a single instance of their having contrived some new feature or modified their habitual routine, and we will cheerfully yield, and admit that they not only possess an admirable instinct, but have also an intellect worthy to approach that of man, worthy to share in one knows not what higher destiny than awaits unconscious and submissive matter.

This language is not even confined to the profane ; it is made use of by entomologists of the rank of Kirby and Spence, in order to deny the bees the possession of intellect other than may vaguely stir within the narrow prison of $3^{64}$ 


\section{The Progress of the Race}

an extraordinary but unchanging instinct. "Show us," they say, "a single case where the.pressure of events has inspired them with the idea, for instance, of substituting clay or mortar for wax or propolis ; show us this, and we will admit their capacity for reasoning."

This argument, that Romanes refers to as the "question-begging argument," and that might also be termed the "insatiable argument," is exceedingly dangerous, and, if applied to man, would take us very far. Examine it closely, and you find that it emanates from the "mere commonsense," which is often so harmful; the "common-sense" that replied to Galileo : "The earth does not turn, for I can see the sun move in the sky, rise in the morning and sink in the evening; and nothing can prevail over the testimony of my eyes." Common-sense makes an admirable, and necessary, background for 


\section{The Life of the Bee}

the mind; but unless it be watched by a lofty disquiet ever ready to remind it, when occasion demand, of the infinity of its ignorance, it dwindles into the mere routine of the baser side of our intellect. But the bees have themselves answered the objection Messrs. Kirby and Spence advanced. Scarcely had it been formulated when another naturalist, Andrew Knight, having covered the bark of some diseased trees with a kind of cement made of turpentine and wax, discovered that his bees were entirely renouncing the collection of propolis, and exclusively using this unknown matter, which they had quickly tested and adopted, and found in abundant quantities, ready prepared, in the vicinity of their dwelling.

And indeed, one-half of the science and practice of apiculture consists in giving free rein to the spirit of initiative possessed by the bees, and in providing 


\section{The Progress of the Race}

their enterprising intellect with opportunities for veritable discoveries and veritable inventions. Thus, for instance, to aid in the rearing of the larva and-nymphs, the bee-keeper will scatter a certain quantity of flour close to the hive when the pollen is scarce of which these consume an enormous quantity. In a state of nature, in the heart of their native forests in the Asiatic valleys, where they existed probably long before the tertiary epoch, the bees can evidently never have met with a substance of this kind. And yet, if care be taken to "bait" some of them with it, by placing them on the flour, they will touch it and test it, they will perceive that its properties more or less resemble those possessed by the dust of the anthers; they will spread the news among their sisters, and we shall soon find every forager hastening to this unexpected, incomprehensible food, which, 


\section{The Life of the Bee}

in their hereditary memory, must be inseparable from the calyx of flowers where their flight, for so many centuries past, has been sumptuously and voluptuously. welcomed.

$$
\text { [98 ] }
$$

It is a little more than a hundred years ago that Huber's researches gave the first serious impetus to our study of the bees, and revealed the elementary important truths that allowed us to observe them with fruitful result. Barely fifty years have passed since the foundation of rational, practical apiculture was rendered possible by means of the movable combs and frames devised by Dzierzon and Langstroth, and the hive ceased to be the inviolable abode wherein all came to pass in a mystery from which death alone stripped the veil. And lastly, less than fifty years have elapsed since the improve- 


\section{The Progress of the Race}

ments of the microscope, of the entomologist's laboratory, revealed the precise secret of the principal organs of the workers, of the mother, and the males. Need we wonder if our knowledge be as scanty as our experience? The bees have existed many thousands of years; we have watched them for ten or twelve lustres. And if it could even be proved that no change has occurred in the hive since we first opened it, should we have the right to conclude that nothing had changed before our first questioning glance? Do we not know that in the evolution of species a century is but as a drop of rain that is caught in the whirl of the river, and that millenaries glide as swiftly over the life of universal matter as single years over the history of $a$ people? 


\section{The Life of the Bee}

\section{[99]}

But there is no warrant for the statement that the habits of the bees are unchanged. If we examine them with an unbiassed eye, and without emerging from the small area lit by our actual experience, we shall, on the contrary, discover marked variations. And who shall tell how many escape us? Were an observer of a hundred and fifty times our height and about seven hundred and fifty thousand times our importance (these being the relations of stature and weight in which we stand to the humble honeyfly), one who knew not our language, and was endowed with senses totally different from our own; were such an one to have been studying us, he would recognise certain curious material transformations in the course of the last two thirds of the century, but would be totally un- 


\section{The Progress of the Race}

able to form any conception of our moral, social, political, economic or religious. evolution.

The most likely of all the scientific hypotheses will presently permit us to connect our domestic bee with the great tribe of the "Apiens," which embraces all wild bees, and where its ancestors are probably to be found. We shall then perceive physiological, social, economic, industrial, and architectural transformations more extraordinary than those of our human evolution. But for the moment we will limit ourselves to our domestic bee properly so called. Of these, sixteen fairly distinct species are known; but, essentially, whether we consider the Apis Dorsata, the largest known to us, or the Apis Florea, which is the smallest, the insect is always exactly the same, except for the slight modifications induced by the climate and by the conditions 


\section{The Life of the Bee}

whereto it has had to conform. ${ }^{1}$ The difference between these various species is scarcely greater than that between an Englishman and a Russian, a Japanese and a European. In these preliminary remarks, therefore, we will confine ourselves to what actually lies within the range of our eyes, refusing the aid of hypothesis, be this never so probable or so imperious. We shall mention no facts

1 The scientific classification of the domestic bee is as follows :

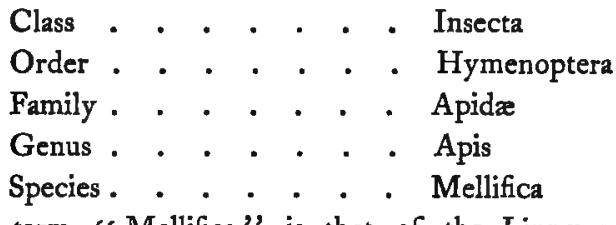

The term "Mellifica" is that of the Linnæan classification. It is not of the happiest, for all the Apidæ, with the exception of certain parasites perhaps, are producers of honey. Scopoli uses the term "Cerifera" ; Réaumur "Domestica "; Geoffroy "Gregaria." The "Apis Ligustica," the Italian bee, is another variety of the "Mellifica." 


\section{The Progress of the Race}

that are not susceptible of immediate proof; and of such facts we will only rapidly refer to some of the more significant.

\section{[100]}

Let us consider first of all the most important and most radical improvement, one that in the case of man would have called for prodigious labour: the external protection of the community.

The bees do not, like ourselves, dwell in towns free to the sky, and exposed to the caprice of rain and storm, but in cities entirely covered with a protecting envelope. In a state of nature, however, in an ideal climate, this is not the case. If they listened only to their essential instinct, they would construct their combs in the open air. In the Indies, the Apis Dorsata will not eagerly seek hollow trees, or a hole in the rocks. The swarm will 


\section{The Life of the Bee}

hang from the crook of a branch; and the comb will be lengthened, the queen lay her eggs, provisions be stored, with no shelter other than that which the workers' own bodies provide. Our Northern bees have at times been known to revert to this instinct, under the deceptive influence of a too gentle sky; and swarms have been found living in the heart of a bush.

But even in the Indies, the result of this habit, which would seem innate, is by no means favourable. So considerable a number of the workers are compelled to remain on one spot, occupied solely with the maintenance of the heat required by those who are moulding the wax and rearing the brood, that the Apis Dorsata, hanging thus from the branches, will construct but a single comb; whereas if she have the least shelter she will erect four or five, or more; and will proportionately increase the prosperity and the population 


\section{The Progress of the Race}

of the colony. And indeed we find that all species of bees existing in cold and temperate regions have abandoned this primitive method. The intelligent initiative of the insect has evidently received the sanction of natural selection, which has allowed only the most numerous and best protected tribes to survive our winters. What had been merely an idea, therefore, and opposed to instinct, has thus by slow degrees become an instinctive habit. But it is none the less true that in forsaking the vast light of nature that was so dear to them and seeking shelter in the obscure hollow of a tree or a cavern, the bees have followed what at first was an audacious idea, based on observation, probably, on experience and reasoning. And this idea might be almost declared to have been as important to the destinies of the domestic bee as was the invention of fire to the destinies of man. 


\section{The Life of the Bee}

$$
\text { [ IOI] }
$$

This great progress, not the less actual for being hereditary and ancient, was followed by an infinite variety of details which prove that the industry, and even the policy, of the hive have not crystallised into infrangible formula. We have already mentioned the intelligent substitution of flour for pollen, and of an artificial cement for propolis. We have seen with what skill the bees are able to adapt to their needs the occasionally disconcerting dwellings into which they are introduced, and the surprising adroitness wherewith they turn combs of foundationwax to good account. They display extraordinary ingenuity in their manner of handling these marvellous combs, which are so strangely useful, and yet incomplete. In point of fact, they meet man half-way. Let us imagine that we had for centuries 


\section{The Progress of the Race}

past been erecting cities, not with stones, bricks, and lime, but with some pliable substance painfully secreted by special organs of our body. One day an allpowerful being places us in the midst of a fabulous city. We recognise that it is made of a substance similar to the one that we secrete, but, as regards the rest, it is a dream, whereof what is logical is so distorted, so reduced, and as it were concentrated, as to be more disconcerting almost than had it been incoherent. Our habitual plan is there; in fact, we find everything that we had expected; but all has been put together by some antecedent force that would seem to have crushed it, arrested it in the mould, and to have hindered its completion. The houses whose height must attain some four or five yards are the merest protuberances, that our two hands can cover. Thousands of walls are indicated by signs that hint 


\section{The Life of the Bee}

at once of their plan and material. Elsewhere there are marked deviations, which must be corrected; gaps to be filled and harmoniously joined to the rest, vast surfaces that are unstable and will need support. The enterprise is hopeful, but full of hardship and danger. It would seem to have been conceived by some sovereign intelligence, that was able to divine most of our desires, but has executed them clumsily, being hampered by its very vastness. We must disentangle, therefore, what now is obscure, we must develop the least intentions of the supernatural donor; we must build in a few days what would ordinarily take us years; we must renounce organic habits, and fundamentally alter our methods of labour. It is certain that all the attention man could devote would not be excessive for the solution of the problems that would arise, or for the turning to fullest account 


\section{The Progress of the Race}

the help thus offered by a magnificent providence. Yet that is, more or less, what the bees are doing in our modern hives. $^{1}$

$$
\text { [102] }
$$

I have said that even the policy of the bees is probably subject to change. This point is the obscurest of all, and the most difficult to verify. I shall not dwell on their various methods of treating the queens, or the laws as to swarming that are peculiar to the inhabitants of every hive, and apparently transmitted from generation to generation, etc.; but by the side of these facts which are not suff-

1 As we are now concerned with the construction of the bee, we may note, in passing, a strange peculiarity of the Apis Florea. Certain walls of its cells for males are cylindrical instead of hexagonal. Apparently she has not yet succeeded in passing from one form to the other, and indefinitely adopting the better. 


\section{The Life of the Bee}

ciently established are others so precise and unvarying as to prove that the same degree of political civilisation has not been attained by all races of the domestic bee, and that, among some of them, the public spirit still is groping its way, seeking perhaps another solution of the royal problem. The Syrian bee, for instance, habitually rears $\mathrm{I} 20$ queens and often more, whereas our Apis Mellifica will rear ten or twelve at most. Cheshire tells of a Syrian hive, in no way abnormal, where 120 dead queen-mothers were found, and 90 living, unmolested queens. This may be the point of departure, or the point of arrival, of a strange social evolution, which it would be interesting to study more thoroughly. We may add that as far as the rearing of queens is concerned, the Cyprian bee approximates to the Syrian. And finally, there is yet another fact which establishes still more 


\section{The Progress of the Race}

clearly that the customs and prudent organisation of the hive are not the results of a primitive impulse, mechanically followed through different ages and climates, but that the spirit which governs the little republic is fully as capable of taking note of new conditions and turning these to the best advantage, as in times long past it was capable of meeting the dangers that hemmed it around. Transport our black bee to California or Australia, and her habits will completely alter. Finding that summer is perpetual and flowers forever abundant, she will after one or two years be content to live from day to day, and gather sufficient honey and pollen for the day's consumption; and, her thoughtful observation of these new features triumphing over hereditary experience, she will cease to make provision for the winter.

${ }^{1}$ Büchner cites an analogous fact. In the Barbadoes, the bees whose hives are in the midst of the refineries, $3^{81}$ 


\section{The Life of the Bee}

In fact it becomes necessary, in order to stimulate her activity, to deprive her systematically of the fruits of her labour.

$$
\text { [ } 103 \text { ] }
$$

So much for what our own eyes can see. It will be admitted that we have mentioned some curious facts, which by no means support the theory that every intelligence is arrested, every future clearly defined, save only the intelligence and future of man.

But if we choose to accept for one moment the hypothesis of evolution, the spectacle widens, and its uncertain, grandiose light soon attains our own destinies. Whoever brings careful attention to bear will scarcely deny, even though it be not evident, the presence in nature of a will that tends to raise a portion of matter to where they find sugar in abundance during the whole year, will entirely abandon their visits to the flowers. 


\section{The Progress of the Race}

a subtler and perhaps better condition, and to penetrate its substance little by little with a mystery-laden fluid that we at first term life, then instinct, and finally intelligence; a will that, for an end we know not, organises, strengthens, and $f a-$ cilitates the existence of all that is. There can be no certainty, and yet many instances invite us to believe that, were an actual estimate possible, the quantity of matter that has raised itself from its beginnings would be found to be ever increas-. ing. A fragile remark, I admit, but the only one we can make on the hidden force that leads us; and it stands for much in a world where confidence in life, until certitude to the contrary reach us, must remain the first of all our duties, at times even when life itself conveys no encouraging clearness to us.

I know all that may be urged against the theory of evolution. In its favour 


\section{The Life of the Bee}

are numerous proofs and most powerful arguments, which yet do not carry irresistible conviction. We must beware of abandoning ourselves unreservedly to the prevailing truths of our time. A hundred years hence, many chapters of a book instinct to-day with this truth, will appear as ancient as the philosophical writings of the eighteenth century seem to us now, full as they are of a too perfect and nonexisting man, or as so many works of the seventeenth century, whose value is lessened by their conception of a harsh and narrow god.

Nevertheless, when it is impossible to know what the truth of a thing may be, it is well to accept the hypothesis that appeals the most urgently to the reason of men at the period when we happen to have come into the world. The chances are that it will be false; but so long as we believe it to be true it will serve a use- 


\section{The Progress of the Race}

ful purpose by restoring our courage and stimulating research in a new direction. It might at the first glance seem wiser, perhaps, instead of advancing these ingenious suppositions, simply to say the profound truth, which is that we do not know. But this truth could only be helpful were it written that we never shall know. In the meanwhile it would induce a state of stagnation within us more pernicious than the most vexatious illusions. We are so constituted that nothing takes us further or leads us higher than the leaps made by our errors. In point of fact we owe the little we have learned to hypotheses that were always hazardous and often absurd, and, as a general rule, less discreet than they are to-day. They were unwise, perhaps, but they kept alive the ardour for research. To the traveller, shivering with cold, who reaches the human Hostelry, it matters little whether he 25 


\section{The Life of the Bee}

by whose side he seats himself, he who has guarded the hearth, be blind or very old. So long as the fire still burn that he has been watching, he has done as much as the best could have done. Well for us if we can transmit this ardour, not as we received it, but added to by ourselves; and nothing will add to it more than this hypothesis of evolution, which goads us to question with an ever severer method and ever increasing zeal all that exists on the earth's surface and in its entrails, in the depths of the sea and expanse of the sky. Reject it, and what can we set up against it, what can we put in its place? There is but the grand confession of scientific ignorance, aware of its knowing nothing - but this is habitually sluggish, and calculated to discourage the curiosity more needful to man than wisdom - or the hypothesis of the fixity of the species and of divine creation, which is less demonstrable than 


\section{The Progress of the Race}

the other, banishes for all time the living elements of the problem, and explains nothing."

$$
\text { [ } 104 \text { ] }
$$

Of wild bees approximatery 4500 varieties are known. It need scarcely be said that we shall not go through the list. Some day, perhaps, a profound study, and searching experiments and observations of a kind hitherto unknown, that would demand more than one lifetime, will throw a decisive light upon the history of the bee's evolution. All that we can do now is to enter this veiled region of supposition, and, discarding all positive statement, attempt to follow a tribe of hymenoptera in their progress towards a more intelligent existence, towards a little more security and comfort, lightly indicating the salient features of this ascension that is spread over many thousands 


\section{The Life of the Bee}

of years. The tribe in question is already known to us; it is that of the "Apiens," whose essential characteristics are so distinct and well-marked that one is inclined to credit all its members with one common ancestor. ${ }^{1}$

The disciples of Darwin, Hermann Müller among others, consider a little wild bee, the Prosopis, which is to be found all over the universe, as the actual representative of the primitive bee whence all have issued that are known to us to-day.

The unfortunate Prosopis stands more

1 It is important that the terms we shall successively employ, adopting the classification of $\mathrm{M}$. Emile

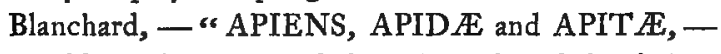
should not be confounded. The tribe of the Apiens comprises all families of bees. The Apidx constitute the first of these families, and are subdivided into three groups: the Meliponx, the Apitæ, and the Bombi (humble-bees). And, finally, the Apitæ include all the different varieties of our domestic bees. 


\section{The Progress of the Race}

or less in the same relation to the inhabitants of our hives as the cave-dwellers to the fortunate who live in our great cities. You will probably more than once have seen her fluttering about the bushes, in a deserted corner of your garden, without realising that you were carelessly watching the venerable ancestor to whom we probably owe most of our flowers and fruits (for it is actually estimated that more than a hundred thousand varieties of plants would disappear if the bees did not visit them) and possibly even our civilisation, for in these mysteries all things intertwine. She is nimble and attractive, the variety most common in France being elegantly marked with white on a black background. But this elegance hides an inconceivable poverty. She leads a life of starvation. She is almost naked, whereas her sisters are clad in a warm and sumptuous fleece. She has not, like 


\section{The Life of the Bee}

the Apidæ, baskets to gather the pollen, nor, in their default, the tuft of the Andrenæ, nor the ventral brush of the Gastrilegidæ. Her tiny claws must laboriously gather the powder from the calices, which powder she needs must swallow in order to take it back to her lair. She has no implements other than her tongue, her mouth and her claws; but her tongue is too short, her legs are feeble, and her mandibles without strength. Unable to produce wax, bore holes through wood, or dig in the earth, she contrives clumsy galleries in the tender pith of dry berries; erects a few awkward cells, stores these with a little food for the offspring she never will see; and then, having accomplished this poor task of hers, that tends she knows not whither and of whose aim we are no less ignorant, she goes off and dies in a corner, as solitarily as she had lived. 


\section{The Progress of the Race}

$$
\text { [ } 105 \text { ] }
$$

We shall pass over many intermediary species, wherein we may see the gradual lengthening of the tongue, enabling more nectar to be extracted from the cups of corollas, and the dawning formation and subsequent development of the apparatus for collecting pollen, - hairs, tufts, brushes on the tibia, on the tarsus, and abdomen, - as also claws and mandibles becoming stronger, useful secretions being formed, and the genius that presides over the construction of dwellings seeking and finding extraordinary improvement in every direction. Such a study would need a whole volume. I will merely outline a chapter of it, less than a chapter, a page, which shall show how the hesitating endeavours of the will to live and be happier result in the birth, development, and affirmation of social intelligence. 


\section{The Life of the Bee}

We have seen the unfortunate Prosopis silently bearing her solitary little destiny in the midst of this vast universe charged with terrible forces. A certain number of her sisters, belonging to species already more skilful and better supplied with utensils, such as the well-clad Colletes, or the marvellous cutter of rose-leaves, the Megachile Centuncularis, live in an isolation no less profound; and if by chance some creature attach itself to them, and share their dwelling, it will either be an enemy, or, more often, a parasite.

For the world of bees is peopled with phantoms stranger than our own; and many a species will thus have a kind of mysterious and inactive double, exactly similar to the victim it has selected, save only that its immemorial idleness has caused it to lose one by one its implements of labour, and that it exists solely 


\section{The Progress of the Race}

at the expense of the working type of its race. ${ }^{1}$

Among the bees, however, which are somewhat too arbitrarily termed the "solitary Apidæ," the social instinct already is smouldering, like a flame crushed beneath the overwhelming weight of matter that stifles all primitive life. And here and there, in unexpected directions, as though reconnoitring, with timid and sometimes fantastic outbursts, it will succeed in piercing the mass that op-

1 The humble-bees, for instance, have the Psithyri as parasites, while the Stelites live on the Anthidia. "As regards the frequent identity of the parasite with its victim," M. J. Perez very justly remarks in his book "The Bees," "one must necessarily admit that the two genera are only different forms of the same type, and are united to each other by the closest affinity. And to naturalists who believe in the theory of evolution this relationship is not purely ideal, but real. The parasitic genus must be regarded as merely a branch of the foraging genus, having lost its foraging organs because of its adaptation to parasitic life." 


\section{The Life of the Bee}

presses it, the pyre that some day shall feed its triumph.

If in this world all things be matter, this is surely its most immaterial movement. Transition is called for from a precarious, egotistic and incomplete life to a life that shall be fraternal, a little more certain, a little more happy. The spirit must ideally unite that which in the body is actually separate; the individual must sacrifice himself for the race, and substitute for visible things the things that cannot be seen. Need we wonder that the bees do not at the first glance realise what we have not yet disentangled, we who find ourselves at the privileged spot whence instinct radiates from all sides into our consciousness? And it is curious too, almost touching, to see how the new idea gropes its way, at first, in the darkness that enfolds all things that come to life on this earth. It emerges 


\section{The Progress of the Race}

from matter, it is still quite material. It is cold, hunger, fear, transformed into something that as yet has no shape. It crawls vaguely around great dangers, around the long nights, the approach of winter, of an equivocal sleep which almost is death. ...

$$
\text { [ } 106 \text { ] }
$$

The Xylocopæ are powerful bees which worm their nest in dry wood. Their life is solitary always. Towards the end of summer, however, some individuals of a particular species, the Xylocopa Cyanescens, may be found huddled together in a shivering group, on a stalk of asphodel, to spend the winter in common. Among the Xylocopæ this tardy fraternity is exceptional, but among the Ceratinæ, which are of their nearest kindred, it has become a constant habit. The idea is germinating. It halts immediately; and hitherto 


\section{The Life of the Bee}

has not succeeded, among the Xylocopæ, in passing beyond this first obscure line of love.

Among other Apiens, this groping idea assumes other forms. The Chalicodomæ of the out-houses, which are buildingbees; the Dasypodæ and Halicti, which dig holes in the earth, unite in large colonies to construct their nests. But it is an illusory crowd composed of solitary units, that possess no mutual understanding, and do not act in common. Each one is profoundly isolated in the midst of the multitude, and builds a dwelling for itself alone, heedless of its neighbour. "They are," M. Perez remarks, "a mere congregation of individuals, brought together by similar tastes and habits, but observing scrupulously the maxim of each one for itself; in fact, a mere mob of workers, resembling the swarm of a hive only as regards their number and zeal. 


\section{The Progress of the Race}

Such assemblies merely result from a great number of individuals inhabiting the same locality."

But when we come to the Panurgi, which are cousins of the Dasypodx, a little ray of light suddenly reveals the birth of a new sentiment in this fortuitous crowd. They collect in the same way as the others, and each one digs its own subterranean chambers; but the entrance is common to all, as also the gallery which leads from the surface of the ground to the different cells. "And thus," M. Perez adds, "as far as the work of the cells is concerned, each bee acts as though she were alone; but all make equal use of the gallery that conducts to the cells, so that the multitude profit by the labours of an individual, and are spared the time and trouble required for the construction of separate galleries. It would be interesting to discover whether 


\section{The Life of the Bee}

this preliminary work be not executed in common, by relays of females, relieving each other in turn."

However this may be, the fraternal idea has pierced the wall that divided two worlds. It is no longer wild and unrecognisable, wrested from instinct by cold and hunger, or by the fear of death ; it is prompted by active life. But it halts once more; and in this instance arrives no further. No matter, it does not lose courage; it will seek other channels. It enters the humble-bee, and, maturing there, becomes embodied in a different atmosphere, and works its first decisive miracles.

$$
\text { [107] }
$$

The humble-bees, the great hairy, noisy creatures that all of us know so well, so harmless for all their apparent fierceness, lead a solitary life at first. At the begin- 


\section{The Progress of the Race}

ning of March the impregnated female who has survived the winter starts to construct her nest, either underground or in a bush, according to the species to which she belongs. She is alone in the world, in the midst of awakening spring. She chooses a spot, clears it, digs it and carpets it. Then she erects her somewhat shapeless waxen cells, stores these with honey and pollen, lays and hatches the eggs, tends and nourishes the larvæ that spring to life, and soon is surrounded by a troop of daughters who aid her in all her labours, within the nest and without, while some of them soon begin to lay in their turn. The construction of the cells improves; the colony grows, the comfort increases. The foundress is still its soul, its principal mother, and finds herself now at the head of a kingdom which might be the model of that of our honeybee. But the model is still in the rough. 


\section{The Life of the Bee}

The prosperity of the humble-bees never exceeds a certain limit, their laws are illdefined and ill-obeyed, primitive cannibalism and infanticide reappear at intervals, the architecture is shapeless and entails much waste of material; but the cardinal difference between the two cities is that the one is permanent, and the other ephemeral. For, indeed, that of the humble-bee will perish in the autumn; its three or four hundred inhabitants will die, leaving no trace of their passage or their endeavours; and but a single female will survive, who, the next spring, in the same solitude and poverty as her mother before her, will recommence the same useless work. The idea, however, has now grown aware of its strength. Among the humble-bees it goes no further than we have stated, but, faithful to its habits and pursuing its usual routine, it will immediately undergo a sort of unwearying 


\section{The Progress of the Race}

metempsychosis, and re-incarnate itself, trembling with its last triumph, rendered all-powerful now and nearly perfect, in another group, the last but one of the race, that which immediately precedes our domestic bee wherein it attains its crown; the group of the Meliponitæ, which comprises the tropical Meliponæ and Trigonæ.

$$
\text { [108] }
$$

Here the organisation is as complete as in our hives. There is an unique mother, there are sterile workers and males. Certain details even seem better devised. The males, for instance, are not wholly idle; they secrete wax. The entrance to the hive is more carefully guarded; it has a door that can be closed when nights are cold, and when these are warm a kind of curtain will admit the air.

But the republic is less strong, general 26 401 


\section{The Life of the Bee}

life less assured, prosperity more limited, than with our bees; and wherever these are introduced, the Meliponitz tend to disappear before them. In both races the fraternal idea has undergone equal and magnificent development, save in one point alone, wherein it achieves no further advance among the Meliponita than among the limited offspring of the humble-bees. In the mechanical organisation of distributed labour, in the precise economy of effort; briefly, in the architecture of the city, they display manifest inferiority. As to this I need only refer to what I said in section 42 of this book, while adding that, whereas in the hives of our Apitæ all the cells are equally available for the rearing of the brood and the storage of provisions, and endure as long as the city itself, they serve only one of these purposes among the Meliponitæ, and the cells employed as cradles for the 


\section{The Progress of the Race}

nymphs are destroyed after these have been hatched. ${ }^{1}$ It is in our domestic bees, therefore, that the idea, of whose. movements we have given a cursory and incomplete picture, attains its most perfect form. Are these movements definitely, and for all time, arrested in each one of these species, and does the connecting-line exist in our imagination alone? Let us not be too eager to establish a system in this ill-explored region. Let our conclusions be only provisional, and preferentially such as convey the utmost hope;

1 It is not certain that the principle of unique royalty, or maternity, is strictly observed among the Meliponitz. Blanchard remarks very justly, that as they possess no sting and are consequently less readily able than the mothers of our own bees to kill each other, several queens will probably live together in the same hive. But certainty on this point has hitherto been unattainable owing to the great resemblance that exists between queens and workers, as also to the impossibility of rearing the Meliponitæ in our climate. 


\section{The Life of the Bee}

for, were a choice forced upon us, occasional gleams would appear to declare that the inferences we are most desirous to draw will prove to be truest. Besides, let us not forget that our ignorance still is profound. We are only learning to open our eyes. A thousand experiments that could be made have as yet not even been tried. If the Prosopes, for instance, were imprisoned, and forced to cohabit with their kind, would they, in course of time, overstep the iron barrier of total solitude, and be satisfied to live the common life of the Dasypodx, or to put forth the fraternal effort of the Panurgi? And if we imposed abnormal conditions upon the Panurgi, would these, in their turn, progress from a general corridor to general cells? If the mothers of the humblebees were compelled to hibernate together, would they arrive at a mutual understanding, a mutual division of labour? Have 


\section{The Progress of the Race}

combs of foundation-wax been offered to the Meliponitæ? Would they accept them, would they make use of them, would they conform their habits to this unwonted architecture? Questions, these, that we put to very tiny creatures; and yet they contain the great word of our greatest secrets. We cannot answer them, for our experience dates but from yesterday. Starting with Réaumur, about a hundred and fifty years have elapsed since the habits of wild bees first received attention. Réaumur was acquainted with only a few of them; we have since then observed a few more; but hundreds, thousands perhaps, have hitherto been noticed only by hasty and ignorant travellers. The habits of those that are known to us have undergone no change since the author of the "Memoirs" published his valuable work; and the humble-bees, all powdered with gold, and vibrant as the 405 


\section{The Life of the Bee}

sun's delectable murmur, that in the year I $73^{\circ}$ gorged themselves with honey in the gardens of Charenton, were absolutely identical with those that to-morrow, when April returns, will be humming in the woods of Vincennes, but a few yards away. From Réaumur's day to our own, however, is but as the twinkling of an eye ; and many lives of men, placed end to end, form but a second in the history of Nature's thought.

$$
\text { [ } 109 \text { ] }
$$

Although the idea that our eyes have followed attains its supreme expression in our domestic bees, it must not be inferred therefrom that the hive reveals no faults. There is one masterpiece, the hexagonal cell, that touches absolute perfection, - a perfection that all the geniuses in the world, were they to meet in conclave, could in no way enhance. No living 406 


\section{The Progress of the Race}

creature, not even man, has achieved, in the centre of his sphere, what the bee has achieved in her own; and were some one from another world to descend and ask of the earth the most perfect creation of the logic of life, we should needs have to offer the humble comb of honey.

But the level of this perfection is not maintained throughout. We have already dealt with a few faults and shortcomings, evident sometimes and sometimes mysterious, such as the ruinous superabundance and idleness of the males, parthenogenesis, the perils of the nuptial flight, excessive swarming, the absence of pity, and the almost monstrous sacrifice of the individual to society. To these must be added a strange inclination to store enormous masses of pollen, far in excess of their needs; for the pollen, soon turning rancid, and hardening, encumbers the surface of the comb; and 


\section{The Life.of the Bee}

further, the long sterile interregnum between the date of the first swarm and the impregnation of the second queen, etc., etc.

Of these faults the gravest, the only one which in our climates is invariably fatal, is the repeated swarming. But here we must bear in mind that the natural selection of the domestic bee has for thousands of years been thwarted by man. From the Egyptian of the time of Pharaoh to the peasant of our own day, the bee-keeper has always acted in opposition to the desires and advantages of the race. The most prosperous hives are those which throw only one swarm after the beginning of summer. They have fulfilled their maternal duties, assured the maintenance of the stock and the necessary renewal of queens; they have guaranteed the future of the swarm, which, being precocious and ample in numbers, 


\section{The Progress of the Race}

has time to erect solid and well-stored dwellings before the arrival of autumn. If left to themselves, it is clear that these hives and their offshoots would have been the only ones to survive the rigours of winter, which would almost invariably have destroyed colonies animated by different instincts; and the law of restricted swarming would therefore by slow degrees have established itself in our northern races. But it is precisely these prudent, opulent, acclimatised hives that man has always destroyed in order to possess himself of their treasure. $\mathrm{He}$ has permitted only - he does so to this day in ordinary practice - the feeblest colonies to survive; degenerate stock, secondary or tertiary swarms, which have just barely sufficient food to subsist through the winter, or whose miserable store he will supplement perhaps with a few droppings of honey. The result is, 409 


\section{The Life of the Bee}

probably, that the race has grown feebler, that the tendency to excessive swarming has been hereditarily developed, and that to-day almost all our bees, particularly the black ones, swarm too often. For some years now the new methods of "movable" apiculture have gone some way towards correcting this dangerous habit; and when we reflect how. rapidly artificial selection acts on most of our domestic animals, such as oxen, dogs, pigeons, sheep and horses, it is permissible to believe that we shall before long have a race of bees that will entirely renounce natural swarming and devote all their activity to the collection of honey and pollen.

$$
\text { [ } 110 \text { ] }
$$

But for the other faults : might not an intelligence that possessed a clearer consciousness of the aim of common life 


\section{The Progress of the Race}

emancipate itself from them? Much might be said concerning these faults, which emanate now from what is unknown to us in the hive, now from swarming and its resultant errors, for which we are partly to blame. But let every man judge for himself, and, having seen what has gone before, let him grant or deny intelligence to the bees, as he may think proper. I am not eager to defend them. It seems to me that in many circumstances they give proof of understanding, but my curiosity would not be less were all that they do done blindly. It is interesting to watch a brain possessed of extraordinary resources within itself wherewith it may combat cold and hunger, death, time, space, and solitude, all the enemies of matter that is springing to life; but should a creature succeed in maintaining its little profound and complicated existence without overstepping 


\section{The Life of the Bee}

the boundaries of instinct, without doing anything but what is ordinary, that would be very interesting too, and very extraordinary. Restore the ordinary and the marvellous to their veritable place in the bosom of nature, and their values shift; one equals the other. We find that their names are usurped; and that it is not they, but the things we cannot understand or explain that should arrest our attention, refresh our activity, and give a new and juster form to our thoughts and feelings and words. There is wisdom in attaching oneself to nought beside.

$$
\text { [ I I I ] ] }
$$

And further, our intellect is not the proper tribunal before which to summon the bees, and pass their faults in review. Do we not find, among ourselves, that consciousness and intellect long will dwell in the midst of errors and faults without 


\section{The Progress of the Race}

perceiving them, longer still without effecting a remedy? If a being exist whom his destiny calls upon most specially, almost organically, to live and to organise common life in accordance with pure reason, that being is man. And yet see what he makes of it, compare the mistakes of the hive with those of our own 'society. How should we marvel, for instance, were we bees observing men, as we noted the unjust, illogical distribution of work among a race of creatures that in other directions appear to manifest eminent reason! We should find the earth's surface, unique source of all common life, insufficiently, painfully cultivated by two or three tenths of the whole population; we should find another tenth absolutely idle, usurping the larger share of the products of this first labour; and the remaining seven-tenths condemned to a life of perpetual half-hunger, ceaselessly exhaust- 


\section{The Life of the Bee}

ing themselves in strange and sterile efforts whereby they never shall profit, but only shall render more complex and more inexplicable still the life of the idle. We should conclude that the reason and moral sense of these beings must belong to' a world entirely different from our own, and that they must obey principles hopelessly beyond our comprehension. But let us carry this review of our faults no further. They are always present in our thoughts, though their presence achieves but little. From century to century only will one of them for a moment shake off its slumber, and send forth a bewildered cry; stretch the aching arm that supported its head, shift its position, and then lie down and fall asleep once more, until a new pain, born of the dreary fatigue of repose, awaken it afresh. 


\section{The Progress of the Race}

$$
\text { [ } \left.\begin{array}{lll}
1 & 1 & 2
\end{array}\right]
$$

The evolution of the Apiens, or at least of the Apitæ, being admitted, or regarded as more probable than that they should have remained stationary, let us now consider the general, constant direction that this evolution takes. It seems - to follow the same roads as with ourselves. It tends palpably to lessen the struggle, insecurity, and wretchedness of the race, to augment authority and comfort, and stimulate favourable chances. To this end it will unhesitatingly sacrifice the individual, bestowing general strength and happiness in exchange for the illusory and mournful independence of solitude. It is as though Nature were of the opinion with which Thucydides credits Pericles: viz., that individuals are happier in the bosom of a prosperous city, even though they suffer themselves, than when indi- 


\section{The Life of the Bee}

vidually prospering in the midst of a languishing state. It protects the hardworking slave in the powerful city, while those who have no duties, whose association is only precarious, are abandoned to the nameless, formless enemies who dwell in the minutes of time, in the movements of the universe, and in the recesses of space. This is not the moment to discuss the scheme of nature, or to ask ourselves whether it would be well for man to follow it; but it is certain that wherever the infinite mass allows us to seize the appearance of an idea, the appearance takes this road whereof we know not the end. Let it be enough that we note the persistent care with which nature preserves, and fixes. in the evolving race, all that has been won from the hostile inertia of matter. She records each happy effort, and contrives we know not what special and benevolent laws to counteract 416 


\section{The Progress of the Race}

the inevitable recoil. This progress, whose existence among the most intelligent species can scarcely be denied, has perhaps no aim beyond its initial impetus, and knows not whither it goes. But at least, in a world where nothing save a few facts of this kind indicates a precise will, it is significant enough that we should see certain creatures rising thus, slowly and continuously; and should the bees have revealed to us only this mysterious spiral of light in the overpowering darkness, that were enough to induce us not to regret the time we have given to their little gestures and humble habits, which seem so far away and are yet so nearly akin to our grand passions and arrogant destinies.

$$
\text { [ } \left.\begin{array}{lll}
1 & 1 & 3
\end{array}\right]
$$

It may be that these things are all vain; and that our own spiral of light, no less than that of the bees, has been kindled for 


\section{The Life of the Bee}

no other purpose save that of amusing the darkness. So, too, is it possible that some stupendous incident may suddenly surge from without, from another world, from a new phenomenon, and either inform this effort with definitive meaning, or definitively destroy it. But we must proceed on our way as though nothing abnormal could ever befall us. Did we know that to-morrow some revelation, a nessage, for instance, from a more ancient, more luminous planet than ours, were to root up our nature, to suppress the laws, the passions, and racical truths of our being; our wisest plan still would be to devote the whole of to-day to the study of these passions, these laws, and these truths, which must blend and accord in our mind; and to remain faithful to the destiny imposed on us, which is to subdue, and to some extent raise within and around us the obscure forces of life. 418 


\section{The Progress of the Race}

None of these, perhaps, will survive the new revelation; but the soul of those who shall up to the end have fulfilled the mission that is pre-eminently the mission of man, must inevitably be in the front rank of all to welcome this revelation; and should they learn therefrom that indifference, or resignation to the unknown, is the veritable duty, they will be better equipped than the others for the comprehension of this final resignation and indifference, better able to turn these to account.

$$
\text { [ I14] }
$$

But such speculations may well be avoided. Let not the possibility of general annihilation blur our perception of the task before us; above all, let us not count on the miraculous aid of chance. Hitherto, the promises of our imagination notwithstanding, we have always been 


\section{The Life of the Bee}

left to ourselves, to our own resources. It is to our humblest efforts that every useful, enduring achievement of this earth is due. It is open to us, if we choose, to await the better or worse that may follow some alien accident, but on condition that such expectation shall not hinder our human task. Here again do the bees, as Nature always, provide a most excellent lesson. In the hive there has truly been prodigious intervention. The bees are in the hands of a power capable of annihilating or modifying their race, of transforming their destinies; the bees' thraldom is far more definite than our own. Therefore none the less do they perform their profound and primitive duty. And, among them, it is precisely those whose obedience to duty is most complete who are able most fully to profit by the supernatural intervention that to-day has raised the destiny of their 


\section{The Progress of the Race}

species. And indeed, to discover the unconquerable duty of a being is less difficult than one imagines. It is ever to be read in the distinguishing organs, whereto the others are all subordinate. And just as it is written in the tongue, the stomach, and mouth of the bee that it must make honey, so is it written in our eyes, our ears, our nerves, our marrow, in every lobe of our head, that we must make cerebral substance; nor is there need that we should divine the purpose this substance shall serve. The bees know not whether they will eat the honey they harvest, as we know not who it is shall reap the profit of the cerebral substance we shall have formed, or of the intelligent fluid that issues therefrom and spreads over the universe, perishing when our life ceases or persisting after our death. As they go from flower to flower collecting more honey than themselves and their offspring 


\section{The Life of the Bee}

can need, let us go from reality to reality seeking food for the incomprehensible flame, and thus, certain of having fulfilled our organic duty, preparing ourselves for whatever befall. Let us nourish this flame on our feelings and passions, on all that we see and think, that we hear and touch, on its own essence, which is the idea it derives from the discoveries, experience and observation that result from its every movement. A time then will come when all things will turn so naturally to good in a spirit that has given itself to the loyal desire of this simple human duty, that the very suspicion of the possible aimlessness of its exhausting effort will only render the duty the clearer, will only add more purity, power, disinterestedness, and freedom to the ardour wherewith it still seeks. 


\section{Appendix}

70 give a complete bibliography of the 1 bee were outside the scope of this book; we shall be satisfied, therefore, merely to indicate the more interesting works :-

I. The Historical Development of Apiarian Science :

(a) The ancient writers : Aristotle, "History of Animals" (Trans. Bart. St. Hilaire); T. Varro, "De Agricultura," L. III. xvi.; Pliny, “ Hist. Nat.," L. xi. ; Columella, “ De Re Rustica;" Palladius, "De Re Rustica," L. I. xxxvii., etc.

(b) The moderns: Swammerdam, "Biblia Naturæ," 1737; Maraldi, “Observations sur les Abeilles," 1712; Réaumur, "Mémoires pour servir à l'Histoire des Insectes," 1740 ; Ch. Bonnet, "CEuvres d'Histoire Naturelle," 1779-1 783; A. G. Schirach, "Physikalische 


\section{The Life of the Bee}

Untersuchung der bisher unbekannten aber nachher entdeckten Erzeugung der Bienenmutter," I767 ; J. Hunter, “ On Bees" (Philosophical Transactions, 1732); J. A. Janscha, "Hinterlassene Vollständige Lehre von der Bienenzucht," I773; François Huber, "Nouvelles Observations sur les Abeilles," I 794, etc.

\section{Practical Apiculture :}

Dzierzon, "Theorie und Praxis des neuen Bienenfreundes; " Langstroth, "The Honeybee " (translated into French by Ch. Dadant: "L'Abeille et la Ruche," which corrects and completes the original); Georges de Layens and Bonnier, "Cours Complet d'Apiculture ;" Frank Cheshire, "Bees and Bee-keeping" (vol. ii.-Practical); Dr. E. Bevan, "The Honey-bee;" T. W. Cowan, "The British Bee-keeper's Guidebook;" A. Root, "The A B C of Bee-Culture;" Henry Allen, "The Bee-keeper's Handy-book;" L'Abbé Collin, "Guide du Propriétaire des Abeilles;" Ch. Dadant, " Petit Cours d'Apiculture Pratique;" Ed. Bertrand, “Conduite du Rucher;" Weber, "Manuel pratique d'Api- 


\section{Appendix}

culture;" Hamet, "Cours Complet d'Apiculture;" De Bauvoys, "Guide de l'Apiculteur;" Pollmann, "Die Biene und ihre Zucht ;" Jeker, Kramer, and Theiler, "Der Schweizerische Bienenvater;" S. Simmins, "A Modern Bee Farm;" F. W. Vogel, "Die Honigbiene und die Vermehrung der Bienvölker;" Baron A. Von Berlepsch, "Die Biene und ihre Frucht," etc.

General Monographs :

F. Cheshire, "Bees and Bee-keeping" (vol. i. - Scientific); T. W. Cowan, "The Honey-bee ;" J. Perez, "Les Abeilles;" Girard, "Manuel d'Apiculture" (Les Abeilles, Organes et Fonctions); Schuckard, "British Bees;" Kirby and Spence, "Introduction to Entomology;" Girdwoyn, "Anatomie et Physiologie de l'Abeille;" F. Cheshire, "Diagrams on the Anatomy of the Honeybee;" Gunderach, "Die Naturgeschichte der Honigbiene;" L. Buchner, "Geistesleben der Thiere;" O. Bütschli, "Zur Entwicklungsgeschichte der Biene;" J. D. Haviland, "The Social Instincts of Bees, their Origin and Natural Selection." 


\section{The Life of the Bee}

Special Monographs (Organs, Functions, Undertakings, etc.) :

F. Dujardin, "Mémoires sur le Système nerveux des Insectes;" Dumas and Milne Edwards, "Sur la Production de la Cire des Abeilles;" E. Blanchard, "Recherches anatomiques sur le Système nerveux des Insectes;" L. R. D. Brougham, "Observations, Demonstrations, and Experiences upon the Structure of the Cells of Bees;" P. Cameron, "On Parthenogenesis in the Hymenoptera" (Transactions Natural Society of Glasgow, 1888); Erichson, "De Fabrica et Usu Antennarum in Insectis;" B. T. Lowne, "On the Simple and Compound Eyes of Insects" (Philosophical Transactions, 1879); G. K. Waterhouse, "On the Formation of the Cells of Bees and Wasps ;" Dr. C. T. E. von Siebold, "On a True Parthenogenesis in Moths and Bees;" F. Leydig, "Das Auge der Gliederthiere;" Pastor Schonfeld, "Bienen-Zeitung," I854I883; "Illustrierte Bienen-Zeitung," I 885I 890 ; Assmuss, "Die Parasiten der Honigbiene." 


\section{Appendix}

Notes on Melliferous Hymenoptera :

E. Blanchard, " Metamorphoses, Moeurs et Instincts des Insectes;" Vid : " Histoire des Insectes;" Darwin, "Origin of Species;" Fabre, "Souvenirs Entomologiques" ( $3 \mathrm{~d}$ series); Romanes, "Mental Evolution in Animals;" id., "Animal Intelligence ;" Lepeletier et Fargeau, "Histoire Naturelle des Hymenopteres ;" V. Mayet, "Mémoire sur les Mœurs et sur les Metamorphoses d'une Nouvelle Espèce de la Famille des Vesicants" (Ann. Soc. Entom. de France, 1875); H. Müller, "Ein Beitrag zur Lebensgeschichte der Dasypoda Hirtipes ;" E. Hoffer, "Biologische Beobachtungen an Hummeln und Schmarotzerhummeln ;" Jesse, "Gleanings in Natural History ;" Sir John Lubbock, "Ants, Bees, and Wasps ;" id., "The Senses, Instincts, and Intelligence of Animals;" Walkenaer, "Les Haclites;" Westwood, "Introduction to the Study of Insects;" V. Rendu, "De l'Intelligence des Bêtes;" Espinas, "Animal Communities," etc. 






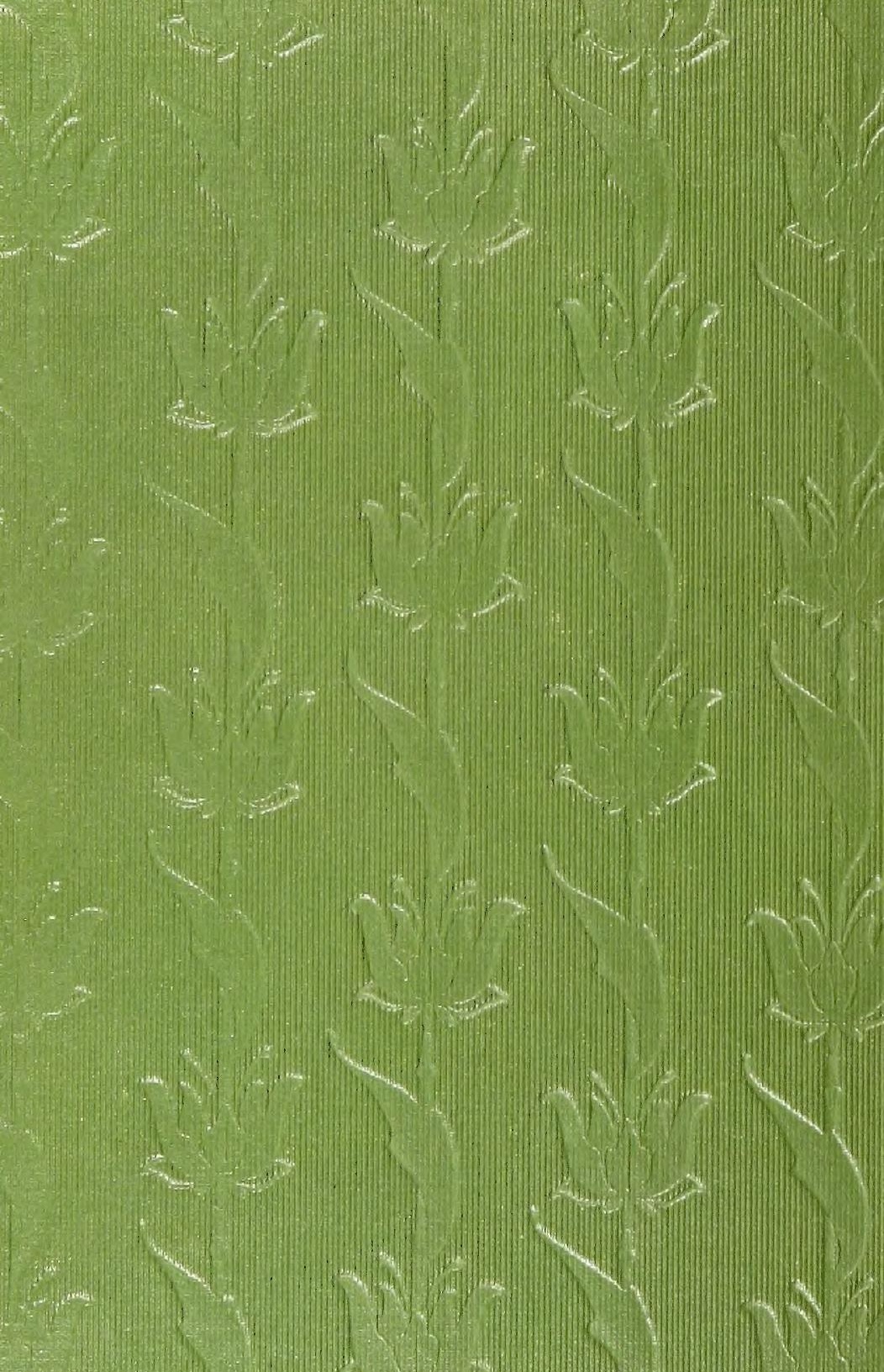

